\author{
UNIVERSIDADE DE SÃO PAULO \\ USP \\ Programa Interunidades de Pós-Graduação em Energia \\ PIPGE \\ (EP/ FEA / IEE / IF)
}

\title{
A PARTICIPAÇÃO DO ETANOL BRASILEIRO EM UMA NOVA PERSPECTIVA NA MATRIZ ENERGÉTICA MUNDIAL
}

Renato Marcoccia

São Paulo

2007 
RENATO MARCOCCIA

\section{A PARTICIPAÇÃO DO ETANOL BRASILEIRO EM UMA NOVA PERSPECTIVA NA MATRIZ ENERGÉTICA MUNDIAL}

Dissertação apresentada ao Programa Interunidades de Pós-Graduação em Energia da Universidade de São Paulo (Instituto de Eletrotécnica e Energia / Escola Politécnica / Instituto de Física / Faculdade de Economia e Administração) para obtenção do título de Mestre em Energia.

Orientação: Prof ${ }^{a}$. Dr ${ }^{\mathrm{a}}$. Patricia H. L.S.Matai

São Paulo 
AUTORIZO A REPRODUÇÃO E DIVULGAÇÃO TOTAL OU PARCIAL DESTE TRABALHO, POR QUALQUER MEIO CONVENCIONAL OU ELETRÔNICO, PARA FINS DE ESTUDO E PESQUISA, DESDE QUE CITADA A FONTE.

FICHA CATALOGRÁFICA

Marcoccia, Renato

A participação do etanol brasileiro em uma nova perspectiva na matriz energética mundial.. /. ; orientadora Patrícia Helena Lara dos Santos Matai. São Paulo, 2007.

95 p.: il.; 29,7cm.

Dissertação (Mestrado - Programa Interunidades de Pós-Graduação em Energia) - EP / FEA / IEE / IF da Universidade de São Paulo.

1. Etanol 2. Cana-de-açúcar 3. Sorgo sacarino

4. Fontes renováveis de energia. I. Universidade de São Paulo. II. Título 
UNIVERSIDADE DE SÃO PAULO

Programa Interunidades de Pós-Graduação em Energia

(EP/FEA/IEE/IF)

RENATO MARCOCCIA

\section{“A PARTICIPAÇÃO DO ETANOL BRASILEIRO EM UMA NOVA PERSPECTIVA NA MATRIZ ENERGÉTICA MUNDIAL"}

Dissertação defendida e aprovada em / / 2007 pela Comissão Julgadora

Prof $^{\mathrm{a}}$. Dr ${ }^{\mathrm{a}}$. Patricia Helena Lara dos Santos Matai - PIPGE/USP

Orientadora e Presidente da Comissão Julgadora

Prof. Dr.

Prof. Dr. 
À minha esposa, meu filho e meus pais.

Meu amor, carinho e respeito por vocês. 


\section{AGRADECIMENTOS}

À minha orientadora Prof. ${ }^{a}$ Dr. ${ }^{a}$ Patrícia Helena Lara dos Santos Matai, pela sua disponibilidade, apoio e contribuição para o desenvolvimento desse trabalho.

Ao Instituto de Eletrotécnica e Energia, Escola Politécnica, Instituto de Física e Faculdade de Economia, Administração e Contabilidade da Universidade de São Paulo pela oportunidade da realização do curso de mestrado.

A todos os professores do Programa Interunidades de Pós-Graduação em Energia que contribuíram para o meu desenvolvimento acadêmico.

Ao Conselho Nacional de Desenvolvimento Científico e Tecnológico - CNPq - Brasil, pelo apoio na realização do presente trabalho.

Aos meus familiares que sempre me apoiaram nessa caminhada.

Ao meu filho Mário que soube compreender a minha ausência em alguns momentos.

À minha esposa Elisa que nunca mediu esforços no apoio ao meu trabalho. 


\section{Resumo}

\section{MARCOCCIA, R. A participação do etanol em uma nova perspectiva na matriz}

energética mundial. 2007. 95 p. Dissertação de mestrado - Programa Interunidades de Pós-Graduação em Energia. Universidade de São Paulo

O etanol é utilizado como combustível desde o início do século XX, porém foi a partir da década de 1970 que sua utilização em larga escala foi concretizada pela primeira vez no mundo. Através do PROÁLCOOL foi estabelecido bases para sua produção, distribuição e comercialização. A cultura da cana-de-açúcar prevaleceu em relação às demais como mandioca e babaçu. Análises do potencial do sorgo sacarino também foram realizadas, mas devido ao desconhecimento desta cultura no Brasil não houve muito progresso na sua utilização. No início do século XXI, motivado por razões ambientais e estratégicas, surge o etanol brasileiro como exemplo de utilização de combustíveis alternativos aos derivados do petróleo. A aceitação do veículo com gerenciamento eletrônico para alimentação de combustíveis diferenciados, popularmente denominados de Flex, impulsionou o uso de etanol em território nacional chamando a atenção do mundo. A constatação de mudanças climáticas mundiais despertou a consciência do uso de hidrocarbonetos e suas conseqüências. A expectativa de um mercado mundial de etanol leva a procura de novas fontes de matérias-primas, uma vez que não se pode e não se deve plantar cana-de-açúcar em todos os lugares ou regiões do planeta. Surge o sorgo sacarino como uma das alternativas. Cultura milenar em vários paises demonstra grande potencial para produção de etanol, seguindo os mesmos procedimentos utilizados para cana, porém com menor ciclo de cultivo e menor necessidade hídrica e tolerância ao tipo de terra a ser cultivado. Seu aproveitamento é apoiado pela FAO em diversos paises, entre eles a China. A adoção por parte dos Estados Unidos do etanol em substituição ao metanol e as metas estabelecidas para a adição à gasolina nos próximos anos, provocou um acelerado aumento na produção de etanol, sendo esta baseada em milho. Diversos paises já se espelham nas experiências brasileiras para obtenção de maior independência energética. As necessidades para o abastecimento, dos mercados interno e externo, refletem as iniciativas de investimentos em novos projetos de novas usinas produtoras de etanol. Paises como China, Suécia, Japão já demonstraram amplo interesse na adoção do etanol como aditivo junto à gasolina. As pesquisas em novos sistemas de produção de etanol motivam instituições e 
empresas a uma busca acelerada para obtenção de processos mais rentáveis e economicamente viáveis.

Palavras-chave: etanol, cana-de-açúcar, sorgo sacarino, fontes renováveis de energia. 


\begin{abstract}
MARCOCCIA, R. The participation of ethanol in a new perspective in the world energetic matrix. 2007. 95 p. Dissertation (máster degree)- Programa Interunidades de Pós Graduação em Energia. University of São Paulo.
\end{abstract}

Ethanol is being used as combustible since the beginning of century XX. However, since the decade of seventy it has been used in large scale in the world. The PROÁLCOOL program established bases for its production, distribution and commercialization. The culture of the sugar cane prevailed in relation to cassava and babaçu. Analyses of the potential of sweet sorghum had been also carried through, but due to the unfamiliarity of this culture in Brazil it did not have much progress in its use. At the beginning of century XXI, motivated for environmental and strategy reasons, Brazilian ethanol appears in the world scenario as an example of use of alternative fuels as substitutes for oil derivatives. The acceptance of vehicles with electronic management for differentiated fuel feeding, known as Flex cars, stimulated the use of ethanol in Brazil calling the attention the world. The knowledge of the worldwide climate changes brought the conscience of the use of hydrocarbons and its consequences. The expectation of a worldwide market of ethanol leads to the search for new sources of fuels. Since sugar cane cannot be planted all over the world due to climate differences, sweet sorghum appears as a promising alternative. Millenarian culture in several countries, it demonstrates a great production potential for the production of ethanol. The same procedures employed for sugar cane can be used. However, the sorghum crops require a lesser cycle of culture and minor water needs and tolerance when compared against sugar cane. Its exploitation is supported by FAO in several countries, being China among them. The adoption of ethanol the United States in substitution to methanol and the goals established for the addition to the gasoline in the next years, has been leading to the increase in the production of ethanol, manufactured from maize. Several countries already have been following the Brazilian path for the attainment of bigger energy independence. The necessities for the supplying of the domestic and external markets reflect the initiatives of investments in new projects of new producing plants of ethanol. Countries such as China, Sweden and Japan already had demonstrated a great interest in the adoption of ethanol as a gasoline additive. The research for new systems of production of ethanol motivates institutions 
and companies to search for the attainment of more income-producing and economically viable processes.

key-words: energy, ethanol, sweet sorghum, sugar cane, renewable energy. 


\section{LISTA DE FIGURAS}

Página.

Figura 1 - Oferta interna de energia em tep de 1940 a $2004 \quad 23$

Figura 2 - Oferta interna de energia em \% de 1940 a 2004

Figura 3 - Oferta interna de energia para o ano de 2005

Figura 4 - Evolução do consumo de petróleo nos EUA 25

Figura 5 - Evolução do preço do petróleo no período de 1960 a 2004

Figura 6 - Vendas de veículos no Brasil de 1979 a 2005

Figura 7 - Produção de álcool etílico de 1974 a 2004

Figura 8 - Curva de aprendizado para produção de etanol no Brasil 30

Figura 9 - Perfil de Produção para o Petróleo e Gás, baseado no consumo de 200531

Figura 10 - Curva de Crescimento das Descobertas 32

Figura 11 - Preço do Petróleo 33

Figura12 - Alterações das Temperaturas Médias nos Hemisférios 34

Figura 13 - Safra de cana no Brasil 35

Figura 14 - Fluxograma de produção de açúcar e álcool 39

$\begin{array}{ll}\text { Figura } 15 \text { - Planta do sorgo sacarino } & 50\end{array}$

Figura 16 - Colmos do sorgo sacarino $\quad 50$

Figura 17 - Grãos no topo dos colmos $\quad 50$

Figura 18 - Grãos do sorgo $\quad 50$

Figura 19 - Fogão a etanol com chama controlada $\quad 51$

Figura 20 - Destilador solar de etanol a partir de sorgo 52

Figura 21 - Painel solar de $32 \mathrm{~m}^{2}$, utilizado na destilação do etanol. 52

Figura 22 - Malha de distribuição existente no Brasil para transporte de

combustíveis $\quad 55$

Figura 23 - Novos trajetos planejados pela Transpetro para exportação do etanol $\quad 57$

Figura 24 - Ciclo de produção do etanol a partir do milho $\quad 60$

Figura 25 - Etanol no mundo em $2003 \quad 62$

Figura 26 - Etanol no mundo em 2013

Figura 27 - Comércio mundial de etanol 63 


\section{LISTA DE TABELAS}

Página

Tabela 1 - Reservas provadas de petróleo no mundo

Tabela 2 - Produção mundial anual em 2004 e 2005

Tabela 3 - Projeção da produção mundial de álcool.

Tabela 4 - Uso de Etanol Misturado à Gasolina

Tabela 5 - Países e Matérias-Primas Adotadas

Tabela 6 - Comparativo: matérias-primas para produção de etanol

Tabela 7 - Matéria-prima, clima e processo produtivo

Tabela 8 - Estimativa de produção de etanol

Tabela 9 - Diferentes tipos de sorgo quanto à forma de utilização

Tabela 10 - Rendimentos de natureza agroindustrial obtidos de colmos de sorgo sacarino Br505 e de cana-de-açúcar nos anos agrícola de 1987/88 e 1988/89

Tabela 11 - Modal de Transporte para o Combustível no Brasil em \%

Tabela 12 - Ganho de produtividade na fermentação

Tabela 13 - Consumo e geração de energia na produção de etanol no Brasil 


\section{LISTA DE SIGLAS E ABREVIATURAS}

ANFAVEA

ART

ASPO

BEN

BP

CENEH

CETESB

CONAB

COPERSUCAR

CRA

CTA

DATAGRO

DBO

DQO

EIA

EUA

F.O.LICHT

FAPESP

GISS

IAA

IBGE

ICRISAT

INT

LAMNET

MAPA

MDIC
Associação Nacional dos Fabricantes de Veículos Automotores

Açúcares e Redutores Totais

Association for the Study of Peak Oil and Gas

Balanço Energético Nacional

British Petroleum

Centro Nacional de Referência do Hidrogênio

Companhia de Tecnologia de Saneamento Ambiental

Companhia Nacional de Abastecimento

Cooperativa dos Produtores de Açúcar e Álcool do Estado de São Paulo

Corn Refiners Association

Centro Tecnológico da Aeronáutica

Empresa de consultoria na área de açúcar e álcool

Demanda Bioquímica de Oxigênio

Demanda Química de Oxigênio

Energy Information Administration

Estados Unidos da América

Consultoria alemã área de açúcar e álcool

Fundação de Amparo à Pesquisa de São Paulo

Goddard Institute for Space Studies

Instituto do Açúcar e Álcool

Instituto Brasileiro de Geografia e Estatística

International Crops Research Institute for the Semi-Arid Tropics

Instituto Nacional de Tecnologia

Latin America Thematic Network on Bioenergy

Ministério da Agricultura, Pecuária e Abastecimento.

Ministério de Desenvolvimento da Indústria e Comércio Exterior 
Ministério de Minas e Energia

MTBE

Metil Tércio Butil Éter

NYBOT

New York Board of trade

ONU

Organização das Nações Unidas

OPEP

Organização dos Países Produtores de Petróleo

PROÁLCOOL Programa Nacional do Álcool

SNA

Sociedade Nacional de Agricultura

UE

União Européia

TRANSPETRO

Subsidiária de Logística da Petrobras

UNICA

União da Agroindústria Canavieira de São Paulo 


\section{LISTA DE SÍMBOLOS E FÓRMULAS}

$\begin{array}{ll}\mathbf{C}_{2} \mathbf{H}_{5} \mathrm{OH} & \text { Fórmula da molécula de etanol } \\ \text { gal } & 1 \text { galão americano } \\ \mathbf{m}^{\mathbf{3}} & \text { metro cúbico } \\ { }^{\mathbf{o}} \mathbf{G L} & \text { Graus Gay Lussac } \\ \mathbf{p H} & \text { potencial hidrogeniônico } \\ \text { tep } & \text { tonelada equivalente de petróleo } \\ \text { ton/ha } & \text { tonelada por hectare } \\ \text { US\$ } & \text { Dólar Americano } \\ \text { US\$/GJ } & \text { Dólar por gigajoule } \\ \mathbf{v} / \mathbf{v} & \text { Volume por volume }\end{array}$




\section{SUMÁRIO}

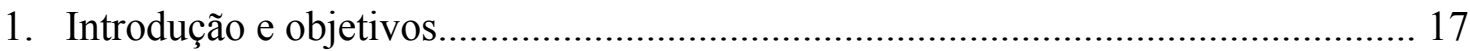

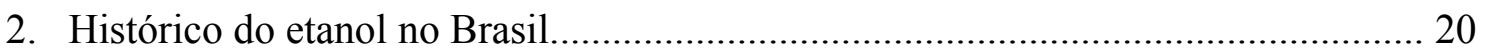

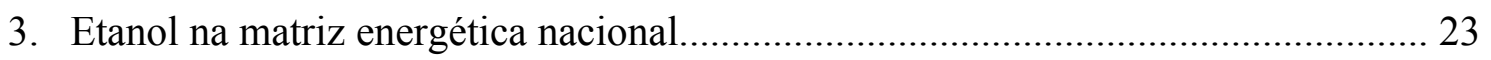

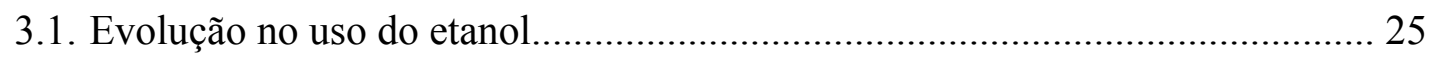

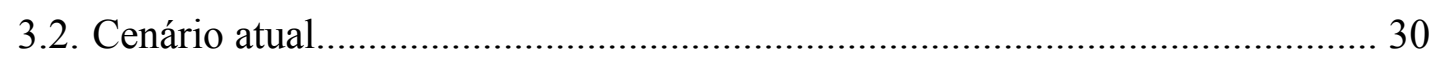

3.3. Cenários futuros................................................................................. 37

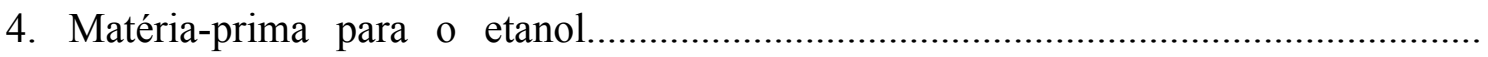
40

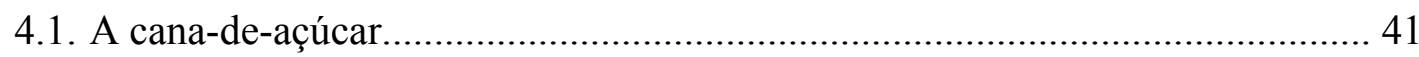

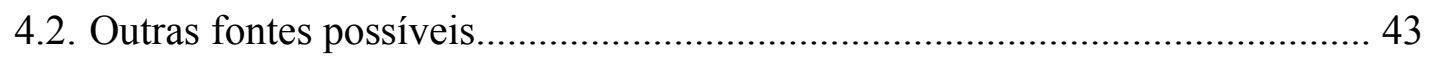

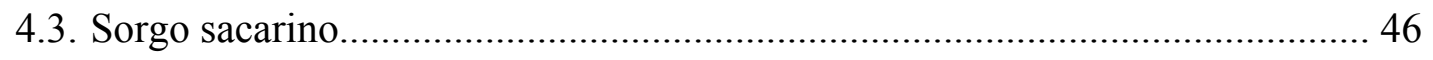

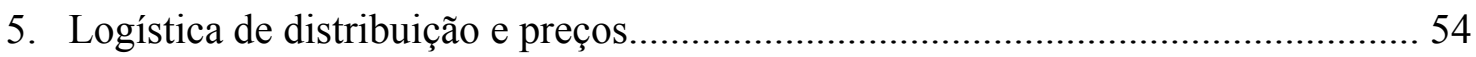

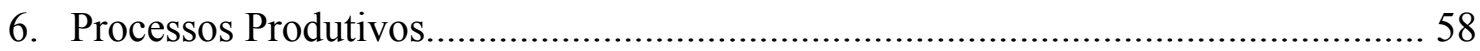

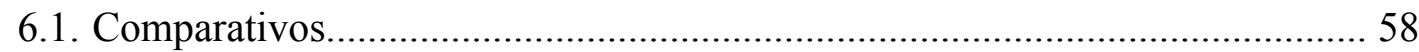

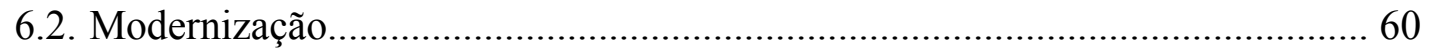

7. A perspectiva de produção mundial de etanol..........................................................62 62

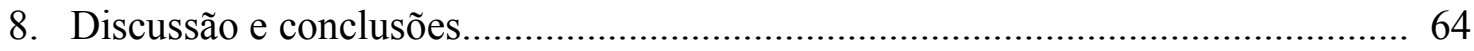

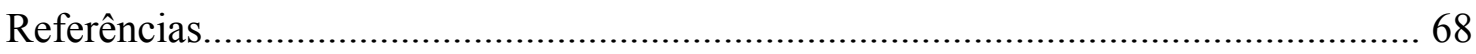

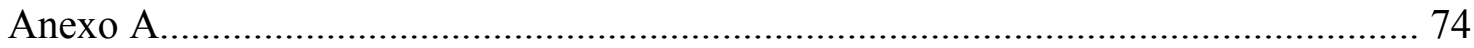

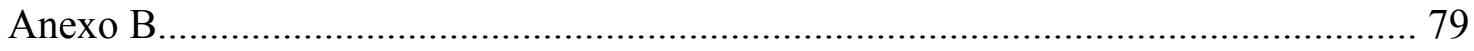

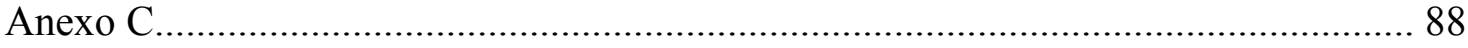




\section{INTRODUÇÃO E OBJETIVOS}

A composição química do etanol, cuja fórmula é $\mathrm{C}_{2} \mathrm{H}_{5} \mathrm{OH}$, foi determinada no século XIX pelo suíço Nicolas-Theodore de Saussure. Henry Ford utilizava o etanol como combustível em motores de combustão interna no início do século XX, porém devido ao baixo custo da gasolina praticado na época viu-se obrigado a adaptar seus motores.

O etanol pode ser obtido por vários processos tendo como fonte de matériasprimas vegetais e hidrocarbonetos. O seu teor é medido em graus Gay Lussac $\left({ }^{\circ} \mathrm{GL}\right)$, referente à quantidade de água incorporada ao álcool.

Durante a segunda guerra mundial quando da impossibilidade de abastecer os seus veículos com gasolina, o exército alemão utilizava o etanol proveniente do processamento de batatas, no abastecimento dos motores de combustão interna (CARVALHO, 2001). De acordo com informativo do Instituto Nacional de Tecnologia (INT, 1979), o primeiro teste com um veículo movido a álcool (a $70^{\circ} \mathrm{GL}$ ) realizado no Brasil data de 1925.

Segundo POOLE (1979), no início da década de 1970, devido à primeira crise do petróleo, muitos países iniciaram pesquisas na procura de fontes alternativas de energia, tais como: eólica, solar e maremotriz. No Brasil, alguns planos neste período foram esboçados e o que melhor rendeu frutos foi o Proálcool (GARNERO, 1980), com a produção de álcool a partir de várias espécies vegetais como: mandioca, babaçu e cana-de-açúcar. Houve uma rápida resposta para a iniciativa governamental, recebendo financiamento de agências governamentais (MENEZES, 1980). Devido à existência de uma indústria açucareira, com tradição desde a época colonial, a cana-de-açúcar foi a que melhor se adaptou (BRANDÃO, 1985). O álcool a partir da cana obteve melhores condições na implantação de sua estrutura, em detrimento ao álcool produzido de outras fontes vegetais como, por exemplo, a mandioca que não dispunha de meios produtivos desenvolvidos e confiáveis. A indústria sucroalcooleira se modernizou e continua alcançando novos patamares de produtividade e desponta como a maior produtora de álcool etílico do mundo (CARVALHO, 2001). 
O aumento significativo do efeito estufa, devido ao acúmulo de materiais lançados na atmosfera, principalmente devido à queima dos combustíveis fósseis, e a perspectiva da diminuição das reservas mundiais do petróleo e de gás natural nas próximas décadas, têm levado a Humanidade a buscar novas formas de prover-se de energia. Neste cenário apresenta-se o etanol, oriundo de fontes renováveis de matériasprimas, como um combustível que possibilita minimizar tais efeitos. No Brasil, sua utilização e produção em larga escala remonta dos anos de 1970. Atualmente percebe-se um aumento crescente na utilização do etanol em vários países devido aos acordos internacionais como o protocolo de Quioto e outros, visando uma alternativa promissora para obtenção de energia complementar e independente de hidrocarbonetos fósseis.

Segundo BURNQUIST (2003), muito se fala na utilização do etanol como combustível. Atualmente, vêem-se países como Estados Unidos, Espanha, França, Japão, Alemanha, Suécia, Índia, China e outros procurando minimizar os efeitos de aditivos, como o chumbo tetraetila, na queima dos combustíveis fósseis utilizados nos veículos, principalmente nas grandes cidades, misturando uma porcentagem de etanol à gasolina, justamente o que vem sendo feito no Brasil há vários anos.

Mercados competitivos como do petróleo, tendem a inferiorizar a produção de etanol, objetivando denegrir o uso do combustível, ressaltando alguns aspectos tecnológicos como: agressão ao meio ambiente com vinhoto, balanço energético negativo no processamento do etanol, danos aos equipamentos automotivos, logística de distribuição precária, etc. Estudos realizados por pesquisadores brasileiros foram enviados ao Banco Mundial a fim de esclarecer todos os progressos experimentados pela indústria sucroalcooleira do Brasil, entre as décadas de 1970 e 2000. Estes estudos mostram o real papel do etanol na geração de empregos, diminuição da poluição nos grandes centros, cuidados com o meio ambiente com aproveitamento de resíduos para a produção de subprodutos e o potencial de crescimento para nações em desenvolvimento (NASTARI et al, 2005). Ao mesmo tempo, vários países, vêm utilizando, como matéria-prima, outros vegetais como: milho, beterraba, madeira e restos florestais subsidiando a produção do etanol e protegendo sua produção em detrimento ao etanol brasileiro. O mercado de etanol como commodity data de maio de 2004 na Bolsa de Mercadorias de Nova Iorque (NYBOT, 2004), e o volume negociado vem aumentando paulatinamente. As maiores preocupações quanto ao uso mundial do etanol se referem à uniformização de padrões técnicos internacionais e a existência de estoques reguladores que possam garantir o fornecimento contratado (SZWRAC, 2006), no Brasil a 
regulamentação para venda e distribuição para o etanol é estabelecida pela Agência Nacional de Petróleo, vide em anexo C.

A larga experiência do Brasil na produção da cana-de-açúcar, desde a época colonial, afiliada ao desenvolvimento agrícola e tecnológico das últimas décadas eleva o país a condição de um potencial competidor nos mercados e referência como gerador de riquezas e fornecedor de tecnologia aos países em desenvolvimento.

O desenvolvimento das pesquisas, seja na área de produção de matéria-prima como na de processamento, continua acelerado sinalizando ganhos significativos em produtividade e eficiência. A possibilidade de ampliação territorial de áreas cultivadas da cana-de-açúcar mais a diversificação com outras culturas para a produção do etanol dão ao Brasil características sem igual no mercado atual de energia. Existem perspectivas, no futuro próximo, que o etanol seja produzido a partir de qualquer fonte de biomassa. A sua utilização como combustível em tecnologias em desenvolvimento, como nas células a combustível, geradores de energia elétrica, por ser rico em hidrogênio, homogêneo, não tóxico, de reforma mais fácil que a da gasolina, originado de matéria-prima renovável e de fácil transporte por ser líquido (CENEH, 2002).

Diante do exposto o objetivo deste trabalho é de analisar o uso do etanol, novos mercados e as possibilidades de produção a partir de novas matérias-primas, somandose ao setor sucroalcooleiro para atender possíveis cenários internacionais e nacionais. 


\section{HISTÓRICO DO ETANOL NO BRASIL}

$\mathrm{Na}$ análise do panorama nacional, hoje se tem em destaque o setor agroindustrial com desempenho positivo em relação ao Produto Interno Bruto (IBGE, 2005). Pertencendo a este setor, ressaltamos o segmento sucroalcooleiro, pela geração de divisas, de empregos diretos e progresso tecnológico. Porém, para alcançar estes níveis, houve muito esforço de pesquisadores, que partindo de condições rudimentares, chegaram a possibilitar a liderança no que tange a seleção de espécies, plantio, logística de colheita e transporte, bem como processamento de resíduo e geração de energia.

A história do emprego do etanol no Brasil data do início do século XX, quando as primeiras tentativas para uso de álcool em veículos foram realizadas pela Sociedade Nacional de Agricultura (SNA). A ocorrência do desabastecimento de combustível, oriundo da Primeira Guerra Mundial em território europeu, trouxe motivação para a realização a partir de 1920, de várias experiências por usinas nordestinas através de utilizações de misturas de combustíveis com álcool, prática que se tornou comum no nordeste (MENEZES, 1980). O uso obrigatório de 5\% de álcool misturado com a gasolina importada, tornou-se realidade com o decreto N. ${ }^{\circ} 9.717$ de 20 de fevereiro de 1931. A experiência com o uso do etanol amadureceu. Relatos de testes de motores ciclo Otto realizados já demonstram o potencial benéfico com relação ao desempenho dos automóveis (VIZIOLI, 1930).

Os primeiros movimentos visando uma melhora do setor sucroalcooleiro, foram estabelecidos com a criação do Instituto do Açúcar e Álcool (IAA) em 1933, possibilitando a organização dos produtores, meios e recursos para financiamento das lavouras e usinas. O decreto $\mathrm{n}^{\circ}{ }^{0} 737$ de $23 / 09 / 1938$, estendeu a mistura de $5 \%$ de álcool à gasolina produzida em território nacional, pela primeira refinaria brasileira de petróleo, a Destilaria Rio-Grandense de Petróleo. No decorrer da Segunda Guerra Mundial, os problemas de abastecimento de petróleo se agravaram. A mistura chegou a ter $42 \%$ de álcool à gasolina. Somente em 1948 pelo decreto lei n. ${ }^{\circ} 25174-A$, foram estabelecidos incentivos à produção do álcool com fins carburantes. Contudo, com o fim do conflito mundial e a busca por petróleo em território nacional, o uso do etanol ficou restrito ao uso industrial e farmacêutico (MENEZES,1980). A indústria canavieira na década de 1950 sofreu com as oscilações dos preços internacionais do açúcar, devido a sua baixa eficiência e atraso tecnológico. Estes fatores e a concorrência internacional trouxeram necessidades urgentes para a sobrevivência do segmento. Em 1959, dez usinas no 
interior de São Paulo, unem-se e fundam a Cooperativa dos Produtores de Açúcar e Álcool do Estado de São Paulo (COPERSUCAR), cujo objetivo principal era proporcionar melhores condições para gerenciamento de estoques e vendas, frente a queda de preços e elevada oferta de açúcar no mercado internacional. Planos visando uma melhor produtividade com redução de custos foram executados o que possibilitou uma recuperação tecnológica e financeira (COPERSUCAR, 2006).

Na década de 1960, o álcool com fins carburantes, ainda era utilizado em pequenas porcentagens. Um novo conflito no Oriente se iniciou entre Árabes e Judeus, a Organização dos Países Produtores de Petróleo (OPEP) lançou em 1973 um embargo de fornecimento de petróleo aos Estados Unidos e Europa o que provoca um aumento dos preços a níveis nunca antes atingidos. Foi o primeiro choque do petróleo. No Brasil, o aumento dos preços e a elevação das contas de importação, conduziram o governo a buscar alternativas, entre as quais estava o Programa Nacional do Álcool (PROÁLCOOL). Em 14 /11/1975 pelo decreto n. ${ }^{\circ} 76.593$ o programa era instituído possibilitando a expansão da produção de álcool com finalidade de uso carburante puro ou em mistura a gasolina e também a indústria química. De 1975 a 1985, a produção da cana-de-açúcar sofreu uma expansão alcançando níveis altíssimos de produtividade e quase toda a frota de veículos carburados era abastecida com etanol. No final dos anos de 1980, os preços do petróleo tenderam a retroceder diminuindo o preço da gasolina e o preço do açúcar no mercado internacional se elevou. O governo não mais subsidiou os preços do álcool, fazendo com que o valor pago pelo álcool ficasse somente $20 \%$ inferior ao da gasolina provocando um desestímulo ao uso do etanol. Novas tecnologias agregadas aos novos motores automotivos à gasolina, como: injeção eletrônica, sensoriamento eletrônico e catalisadores, fizeram com que praticamente todos os veículos produzidos utilizassem este combustível. Com o aumento da demanda por veículos à gasolina a produção de álcool se concentrou no etanol anidro fazendo com que o volume total de consumo do álcool nacional não se alterasse bruscamente (UNICA, 2001).

No início do século XXI, o preço do petróleo encontra-se em nível aceitável, porém acontecimentos marcantes, como a queda das torres gêmeas de Nova York, provocaram a desestabilização econômica do mundo. Conflitos no Afeganistão e Iraque e aumento nos níveis de consumo de petróleo de países em desenvolvimento (China e Índia) pressionam o preço do petróleo a patamares de US\$60 à US\$70. O setor 
sucroalcooleiro, com problemas no mercado internacional de açúcar e elevados estoques de etanol no Brasil, vê o preço despencar.

A indústria automobilística se depara com a utilização errônea do etanol em veículos movidos à gasolina. Surge a possibilidade, com o uso da tecnologia existente, dos setores sucroalcooleiro e automotivo estabelecerem um intercâmbio concebendo assim os veículos denominados Flex $^{1}$, veículos estes, dotados de recursos que possibilitam o abastecimento de qualquer mistura de álcool e gasolina sem danos aos componentes do sistema de abastecimento e propulsão. O mercado apresenta uma ótima recepção da nova tecnologia e em pouco mais de um ano, metade dos veículos produzidos apresenta esta característica. Novos empreendimentos são projetados visando ao aumento da demanda, seja do mercado nacional seja do internacional, na busca por soluções necessárias aos novos critérios adotados por protocolos e acordos cujo objetivo é a melhora das condições e controle das emissões de gases causadores do efeito estufa (NASTARI, 2005).

\footnotetext{
${ }^{1}$ Flex - Denominação para veículos com abastecimento flexível de combustível.
} 


\section{ETANOL NA MATRIZ ENERGÉTICA NACIONAL}

A Matriz Energética Nacional é o conjunto de recursos utilizados para provimento energético a um país. Dentro deste contexto, estão inseridos todos os prováveis elementos de origem, transformação e uso final da energia existente. Os recursos iniciais encontrados na natureza que podem ser usados diretamente ou servem como fonte dos secundários são conhecidos como primários, exemplo: petróleo, energia eólica, carvão mineral, cana. Aqueles gerados ou produzidos a partir da utilização de uma matériaprima ou recurso físico são denominados secundários, exemplo: gasolina, álcool etílico, eletricidade. No Brasil, todos os dados de produção, transformação e consumo energético são analisados e computados segundo metodologia que propõe uma estrutura energética, suficiente-mente geral, de forma a permitir a obtenção de adequada configuração das variáveis físicas próprias do setor energético e são apresentados no Balanço Energético Nacional (BEN). Realizado sob os cuidados do Ministério de Minas e Energia (MME), este balanço tem por finalidade a verificação dos diversos usos da energia, suas necessidades e evolução com o tempo.

Apesar das análises da matriz energética terem se iniciado na década de 1940, o BEN no Brasil teve início na década de 1970, passando por várias modificações até a atualidade. Percebe-se ao analisá-lo, a evolução e alteração dos hábitos das populações, dos meios produtivos e suas necessidades futuras. Uma análise detalhada sobre a forma pelo qual um combustível ou fonte energética interagem com o país, é facilmente evidenciada. As Figuras 1 e 2 mostram respectivamente a evolução dos itens da matriz energética e a oferta interna de energia em toneladas equivalentes de petróleo (tep) e a oferta de energia (\%) referente ao período de 1940 a 2004 extraído do BEN2005 (MME, 2005).

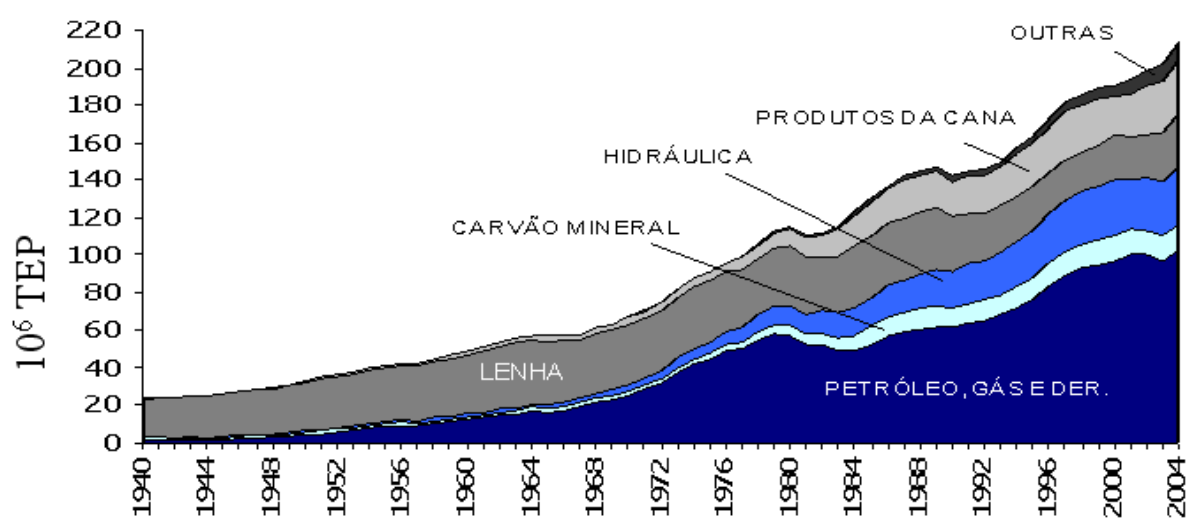

Figura 1 - Oferta interna de energia ( $10^{6}$ tep).

Fonte: (MME, 2005). 


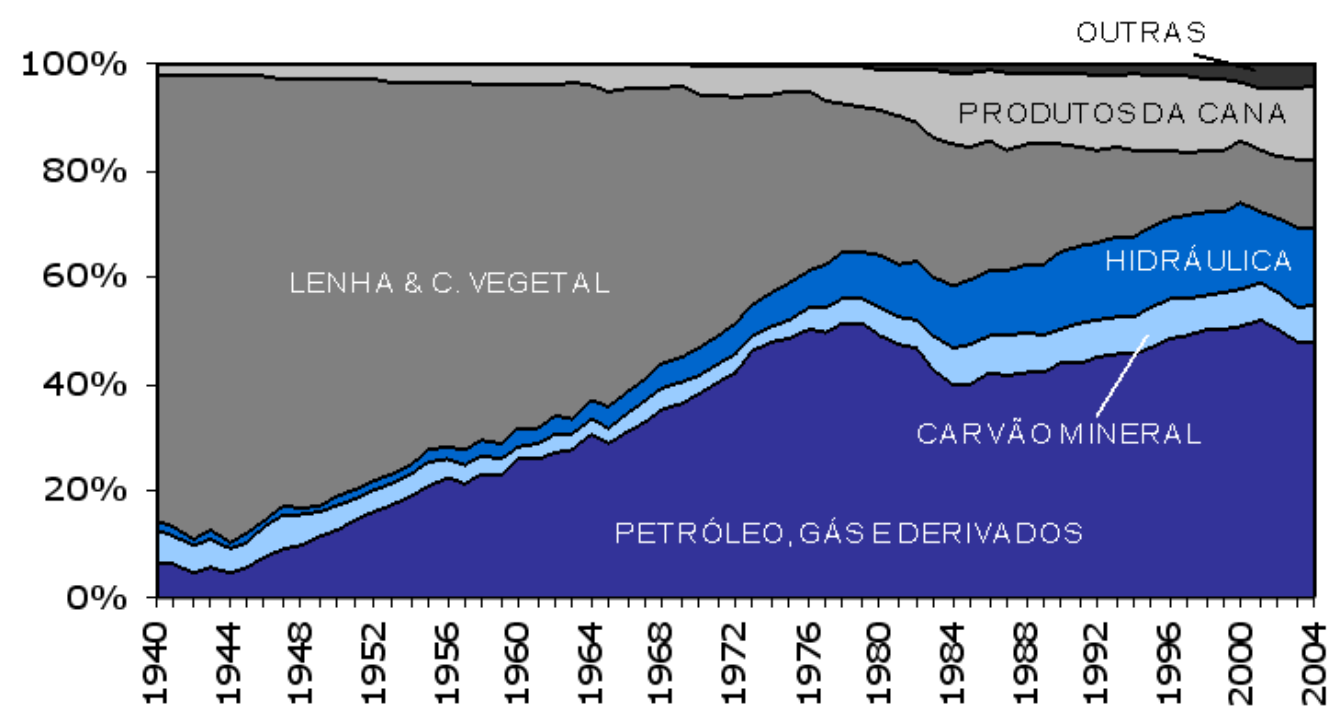

Figura 2 - Oferta de energia (\%).

Fonte: (MME, 2005)

Observa-se que ao longo dos anos, a modificação nos hábitos de consumo energético da população variou, partindo de uma matriz baseada em biomassa de baixa eficiência tecnológica (basicamente lenha e carvão vegetal) para uma maior diversificação com utilização de hidrocarbonetos e energia elétrica, baseada em geração hidráulica. Atualmente, a matriz energética brasileira é formada com um percentual elevado de utilização de biomassa, conforme apresentado na Figura 3 extraído do BEN2006 (MME, 2005).

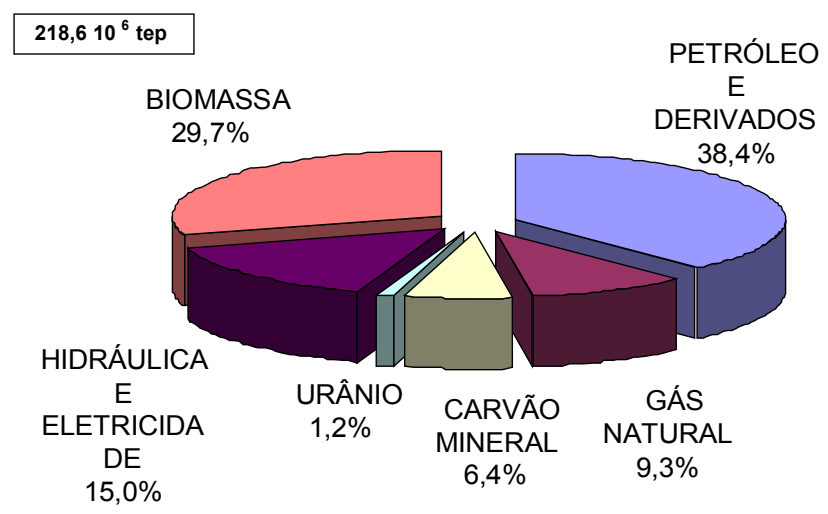

Figura 3 - Oferta interna de energia para o ano de 2005.

Fonte: (MME, 2006) 
Observa-se que de toda energia consumida no Brasil, equivalente a 218,6 tep, são provenientes da biomassa o equivalente a $29,7 \%$, incluídos carvão vegetal, bagaço de cana e etanol. Juntamente aos $15 \%$ de energia elétrica, gerada a partir de potencial hidráulico possibilita ao Brasil ter umas das matrizes energéticas com maior utilização de fontes renováveis do planeta. O consumo de gás natural equivalente a $9,3 \%$ de toda energia permite que o consumo de petróleo e derivados fique na ordem de $38,4 \%$ e economia substancial de divisas e reservas para o país.

\subsection{Evolução no uso do etanol}

A introdução do etanol como combustível se deu no início do século $\mathrm{XX}$, quando do desenvolvimento dos primeiros motores de combustão interna, porém logo suplantada pelo uso de combustíveis provenientes do processamento do petróleo, que na época era obtido a baixo custo devido à grande oferta do produto e grandes reservas nos Estados Unidos da América e Oriente Médio.

O crescimento das indústrias automobilística e petroquímica nas décadas subseqüentes foi extraordinário. Veículos que consumiam enormes quantidades de combustível eram comuns no hemisfério norte tornando-se ícones de progresso e ascensão social. Somente após a constatação de queda de produção dos campos produtores de petróleo dos EUA na década de 1970, conforme pode ser observado na figura 4, e o constante aumento das necessidades energéticas dos países desenvolvidos e em desenvolvimento, o mundo se rendeu ao embargo estabelecido pela OPEP em 1973. Os preços do petróleo elevaram como nunca motivando os países a busca de novas fontes e usos mais eficientes de energia.

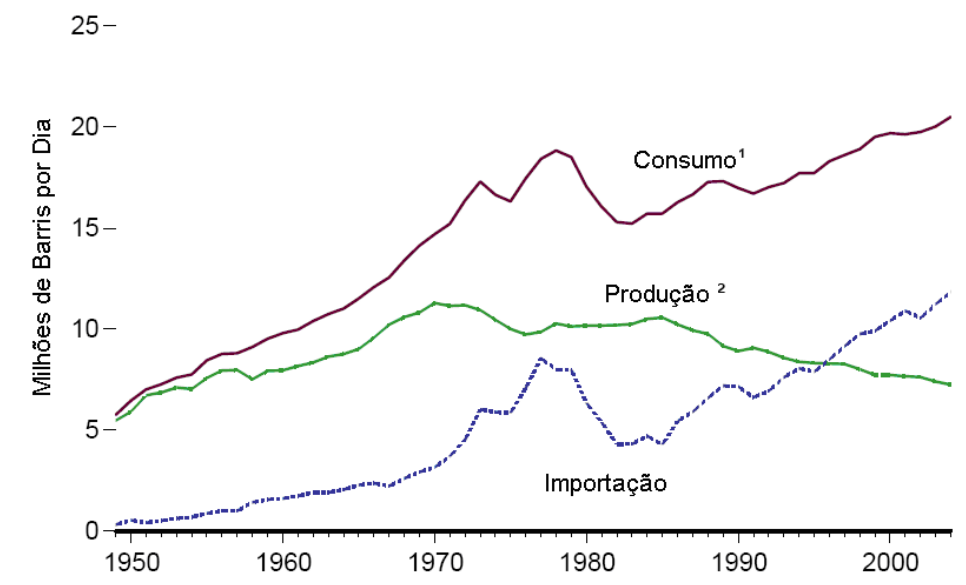

Figura 4 - Evolução do consumo de petróleo nos EUA de 1949-2004. Fonte: (EIA, 2004) 
A figura 4 apresenta a evolução do consumo e produção de petróleo nos EUA entre 1949 e 2004.

De acordo com Bertelli (2005), “A crise internacional elevou os gastos do Brasil com importação de petróleo de US\$ 600 milhões em 1973 para US\$ 2,5 bilhões em 1974. O impacto provocou um déficit na balança comercial de US\$ 4,7 bilhões, resultado que influiu fortemente na dívida externa brasileira (da época e futura) e na escalada da inflação, que saltou de 15,5\% em 1973 para 34,5\% em 1974.”.

Desta forma, a necessidade de uma diversificação na matriz energética e a experiência acumulada no decorrer de anos no setor sucroalcooleiro, levou representantes da sociedade acadêmica e de setores empresariais, à sugestão de utilizar o etanol como combustível nos veículos de ciclo Otto. Após avaliações e desenvolvimento de protótipos de motores no Centro de Tecnologia da Aeronáutica (CTA), o governo federal publicou o Decreto n. ${ }^{\circ}$ 76.593, de 14/11/1975 instituindo o PROÁLCOOL.

As fases de investimentos, subsídios e colocação de metas se sucederam. Em princípio, a produção deveria atender a produção de álcool anidro para suprir a taxa de $20 \%$ a ser adicionada à gasolina, substituindo o chumbo tetraetila elemento tóxico conforme número ONU 1649 ( CETESB, 2006) e posteriormente a adoção como combustível na forma de etanol hidratado. Vale ressaltar que a mistura de álcool como aditivo não era realizada desde o restabelecimento do fornecimento e produção de gasolina após o conflito da Segunda Guerra Mundial. A produção estimada de etanol era de 4,3 bilhões de litros, suficiente para aditivar os 20 bilhões de litros de gasolina consumidos em 1980 (MENEZES, 1980).

Em 1979 o mundo sofre o efeito do segundo choque do petróleo devido à queda do governo do Irã, os preços alcançam patamares nunca antes atingidos. A Figura 5 representa a evolução dos preços do petróleo no período 1968 a 2004.

A resposta do mundo foi a redução, racionalização dos gastos com o petróleo e buscar novas fontes alternativas e sustentáveis. Alguns anos depois com a exploração dos campos no Alasca e Mar do Norte, ocorreu a diminuição paulatina nos níveis de preço até os níveis anteriores. 


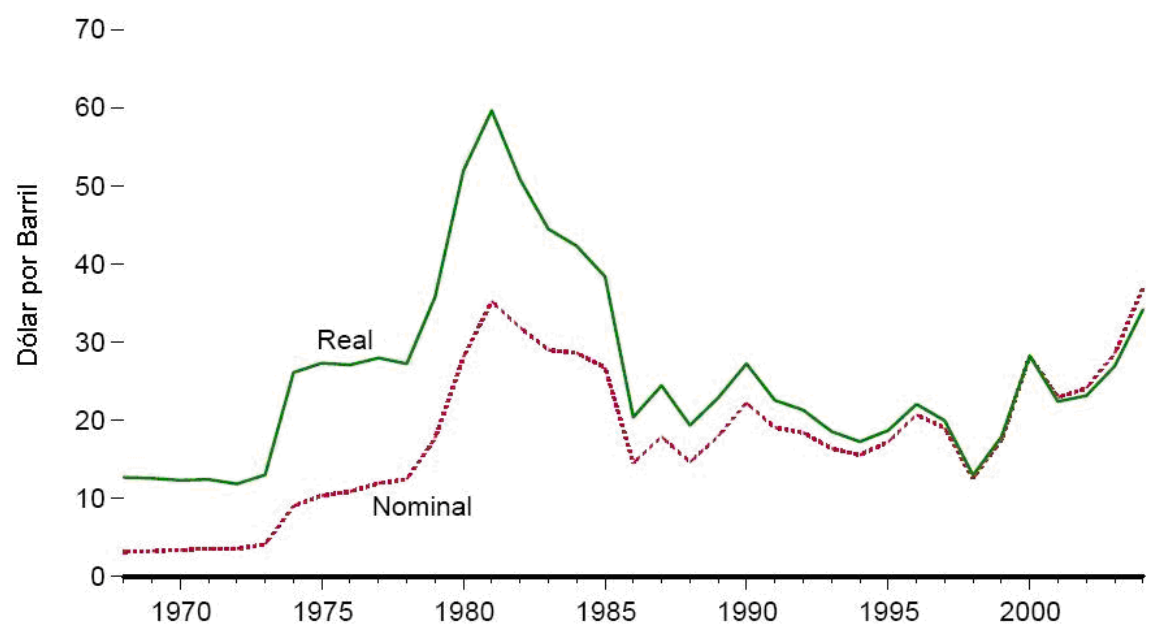

Figura 5 - Evolução² do preço do petróleo no período de 1960 a 2004.

Fonte: (EIA, 2004)

O segundo choque do petróleo proporcionou ao Brasil o amadurecimento e a concretização do PROÁLCOOL. A produção de veículos, com utilização de álcool como combustível, apresentou aumento considerável incentivando ainda mais a construção de novas usinas produtoras de etanol. A Figura 6 ilustra a evolução das vendas $^{3}$ dos veículos movidos a gasolina e álcool no Brasil entre 1979 e 2005, ficando excluídos os veículos Flex. Observa-se um crescente aumento da venda de veículos movidos a álcool entre os períodos de 1979 e 1985 e uma conseqüente queda na de veículos à gasolina devido aos subsídios e incentivos governamentais.

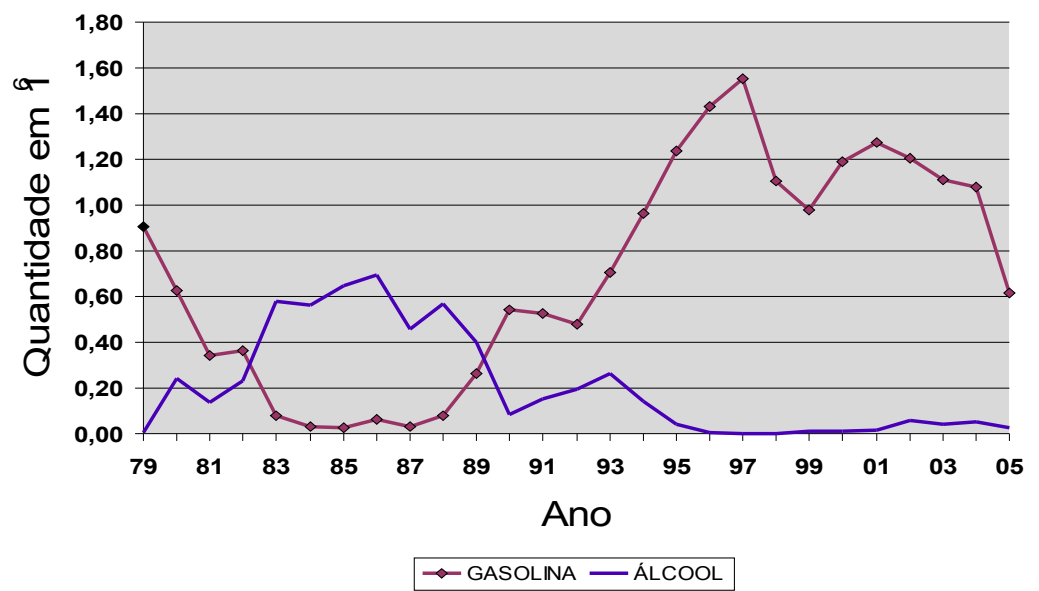

Figura 6 - Evolução das vendas de veículos no Brasil. Fonte: (ANFAVEA, 2006)

\footnotetext{
${ }^{2}$ Valor real calculado a partir de deflator do dólar de 2000.
}

${ }^{3}$ Os dados referentes a 2005 são parciais. 
O Brasil tornou-se o primeiro país a desenvolver uma utilização em massa de um combustível renovável. Obtiveram-se progressos grandiosos no manejo da terra, no desenvolvimento de novas variações de plantas, aumento de produtividade nas questões logísticas. Ano a ano, o Brasil superava suas metas de produção e de abastecimento, tendo sido até 1985, criada uma rede de distribuição para o etanol que contemplava todo território nacional.

Os projetos aprovados pelo PROÁLCOOL somavam 406 destilarias e a capacidade potencial de produção de álcool no país, montava cerca de 12,4 milhões de $\mathrm{m}^{3}$ por safra, correspondentes às unidades produtoras com capacidade instalada e em instalação (NEIVA, 1983).

De acordo com Bertelli (2005), com a queda do preço do petróleo e conseqüente queda do preço da gasolina, o programa do PROÁLCOOL, a partir de 1984, sofre uma diminuição de apoio governamental devido à preocupação com problemas inflacionários e necessidade de controle dos preços. Conforme se observa na figura 6 , a partir de 1986, o início da queda do volume de veículos movidos a álcool.

Neste período até 1996 a diferença do preço do álcool e da gasolina tornou-se cada vez menor. Devido à queda do preço da gasolina e a conseqüente necessidade da redução do preço do álcool ocorreu a diminui nas margens para os produtores, motivando-os à produção de açúcar para o mercado internacional, que a esta altura apresentava elevação nos preços. Os benefícios aos consumidores também foram reduzidos. A falta de subsídios para a produção de etanol e construção de novas usinas e o constante aumento da frota provocou um desabastecimento de álcool, implicando na importação de metanol para adição à gasolina. A modernização do parque automotivo na década de 1990, trouxe ao Brasil novas tecnologias utilizadas na Europa e EUA para veículos movidos à gasolina (ANFAVEA, 2006).

Com o intuito de preservar o parque industrial do setor sucroalcooleiro a produção de etanol concentrou-se basicamente em álcool anidro para ser misturado à gasolina, como aditivo carburante, na proporção de 20 a 25\%. A produção de veículos movidos com combustível renovável caiu a $2 \%$ do total fabricado. A Figura 7 representa a produção de álcool etílico em $10^{6} \mathrm{~m}^{3}$ no período de 1974 a 2004. Observa-se que entre os anos 1987 e 1990 o consumo foi maior que a produção, tal fato é explicado pela diminuição de subsídios governamentais e mudança de preços internacionais do açúcar, o que gerou a necessidade de importação de metanol para suprir a demanda. A partir de 
1995 os preços em queda do açúcar no mercado internacional e os altos estoques internos direcionaram a cana para a produção de álcool provocando um excesso na oferta de etanol entre 1996 e 1998, fazendo com que os preços ficassem bem abaixo dos praticados para a gasolina. Porém, o consumidor perdera a credibilidade no abastecimento do produto.

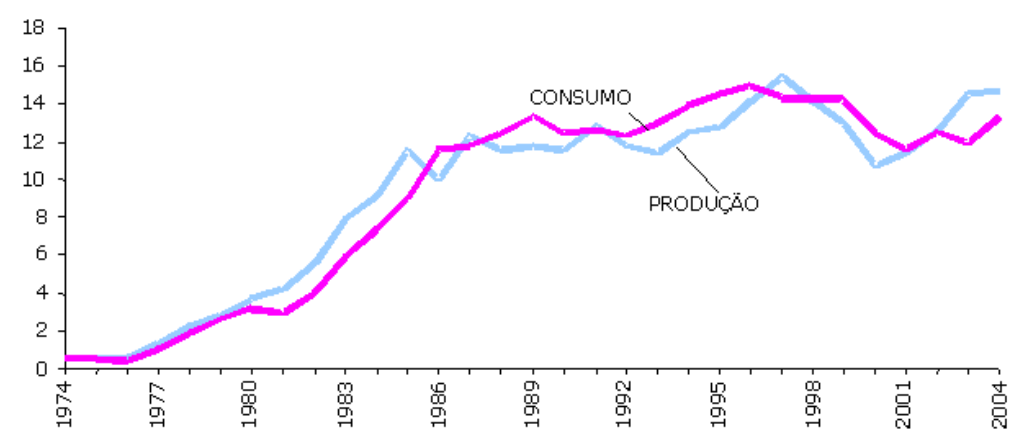

Figura 7 - Produção de álcool etílico no período de 1974 a 2004. Fonte: (MME, 2005).

A perspectiva, para o mercado de etanol do Brasil, no final da década de 1990 indicava que o uso ficaria restrito ao de aditivo carburante, com pequena margem de incremento agregado à produção de veículos e aos limites estabelecidos pelo governo para os níveis de mistura na gasolina. Os níveis do preço do petróleo chegavam, comparativamente, próximos aos estabelecidos no período anterior ao primeiro choque (Figura 5). O mundo crescia a níveis satisfatórios, porém não lembrava ou não conhecia o uso em larga escala do etanol promovido em território brasileiro.

Neste cenário deve-se ressaltar o aprendizado e os ganhos obtidos pelos produtores nacionais, para os quais a constante redução nos custos possibilitou a existência de uma indústria forte que consegue desenvolver-se sem qualquer tipo de subsídio. Quando comparamos o preço do etanol praticado no Brasil e o preço internacional da gasolina (US\$ / GJ) observa-se uma tendência de equiparação, só modificada quando do aumento do preço do petróleo a partir de 2001 conforme apresentado na Figura 8. 


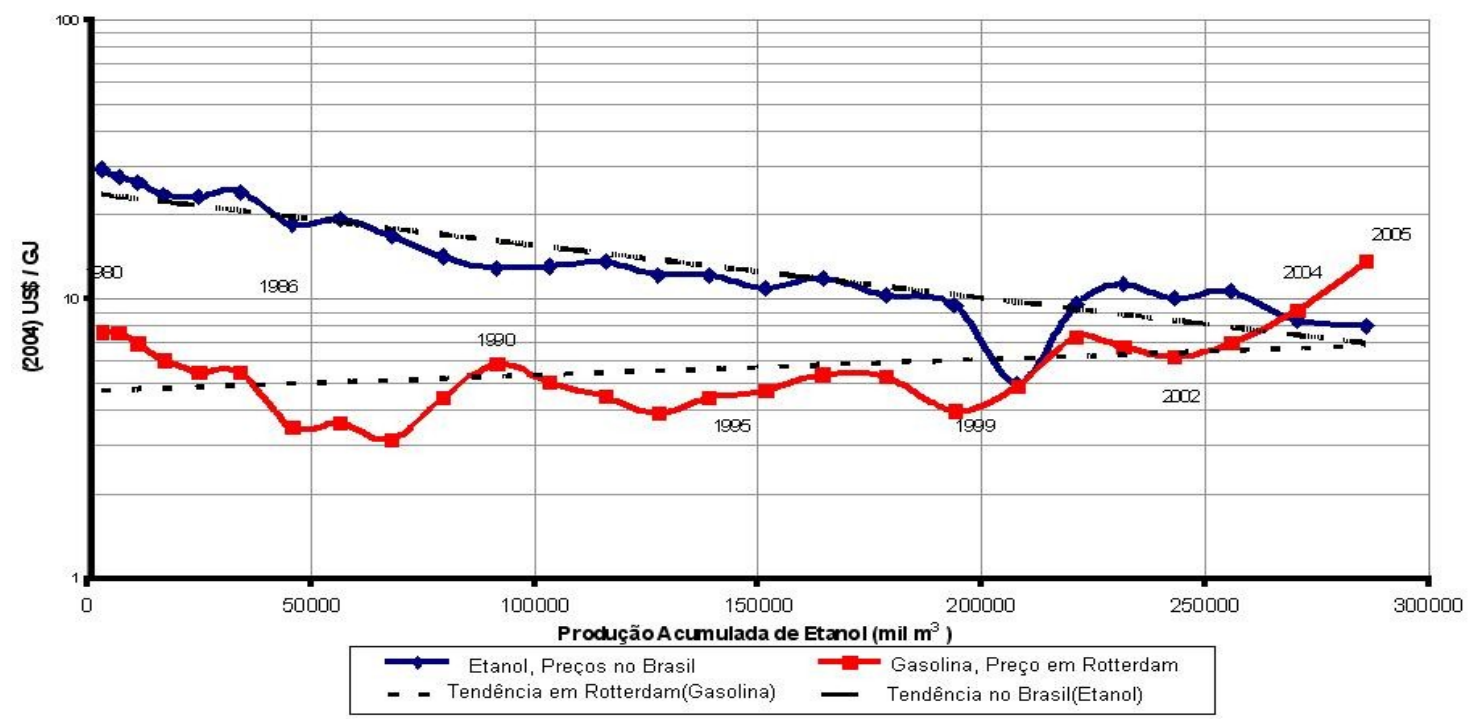

Figura 8 -Curva de aprendizado - Etanol Hidratado Fonte: (Nastari, 2005).

O cenário para o etanol começou a ser alterado em 11 de setembro de 2001, dia em que o mundo parou para ver a queda das torres em Nova Iorque e a reação dos EUA frente a nações como Afeganistão e Iraque que provocaram uma nova escalada no preço internacional do petróleo. Fatores importantes, mas até então considerados como especulações teóricas, também chamaram a atenção do mundo. As reações da natureza ao aquecimento global e às alterações de clima em várias regiões do planeta, bem como os fenômenos de ocorrência natural, tais como furacões mais violentos passaram do campo teórico ao concreto.

\subsection{Cenário atual}

Início do século XXI, o mundo começa a considerar com maior profundidade as questões ambientais. As discussões sobre as alterações climáticas entram em cena e mais de dez anos se passam da Conferência ECO-92 ocorrida no Rio de Janeiro. O apoio ao protocolo de Quioto está próximo de ser aprovado, porém deverá ter o aval das nações que mais utilizam fontes de hidrocarbonetos. A busca pela autonomia energética leva os EUA a forçar uma invasão ao Iraque, fazendo que os preços do petróleo comecem novamente a aumentar. Países que até então eram meros coadjuvantes na 
economia mundial, começam a despontar, tendo o seu crescimento fortes implicações nos preços da energia. Atualmente, têm-se como novos atores, a China e Índia. Para finalizar esta introdução, as constatações de declínio produtivo de campos produtores no Mar do Norte e Alasca provocam nova arrancada em busca de melhores preços.

Estudos sobre a produção mundial de petróleo e gás natural baseados no consumo realizado em 2005 apontam para um rápido alcance do pico de produção e indicam uma inevitável queda de capacidade produtiva conforme indica a Figura 9.

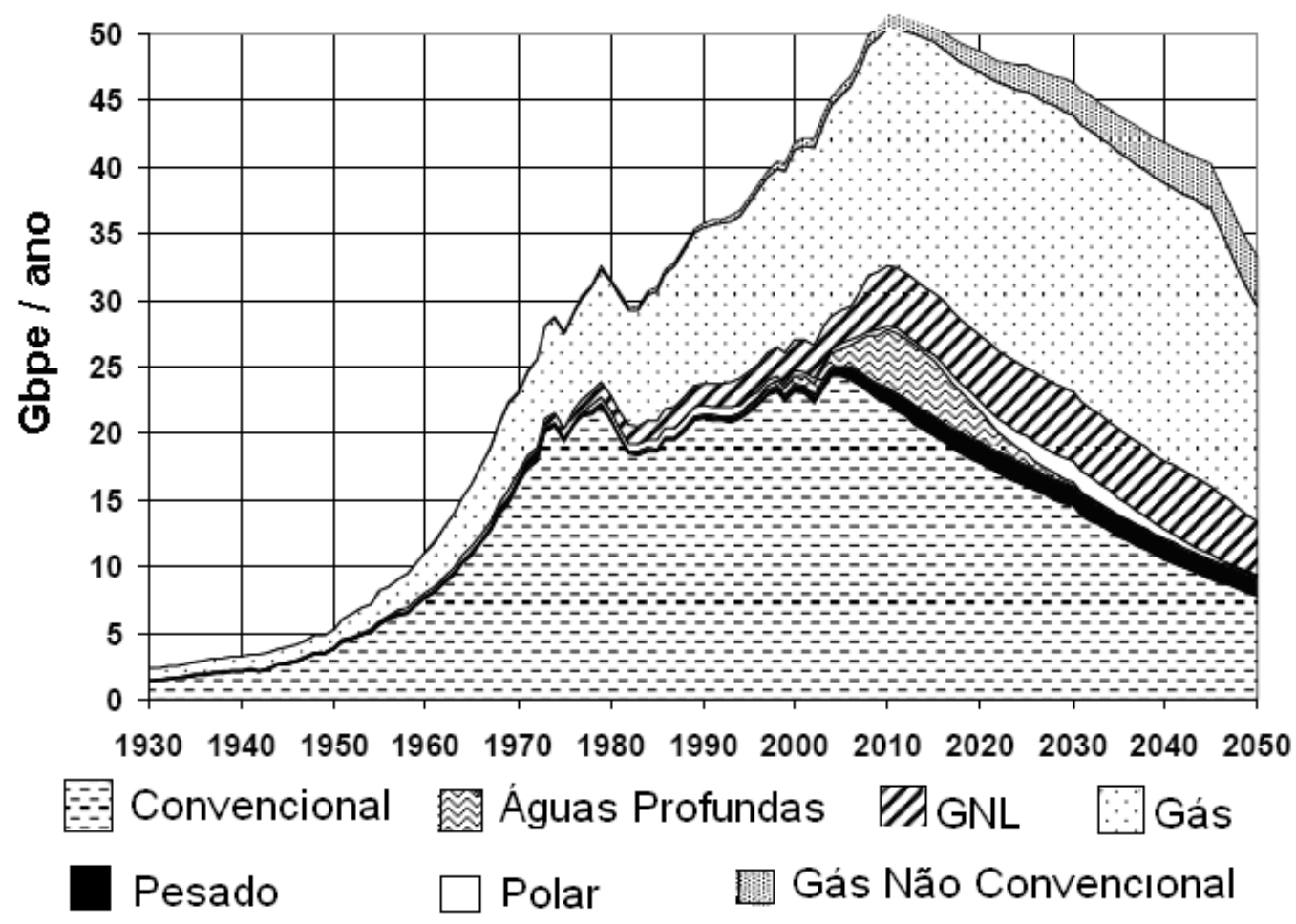

Figura 9 - Perfil de Produção para o Petróleo e Gás, baseado no consumo de 2005. Fonte: (Campbell, C.J., 2006)

Conforme dados das agências internacionais de energia e de produtores de petróleo, como o caso da British Petroleum (BP) em seus boletins anuais, as reservas mundiais de petróleo estão se esgotando. Reservas como as do México caíram vertiginosamente nos últimos anos, assim como reservas do Reino Unido e países nórdicos. As expectativas de produção, caso não haja descobertas expressivas de novas áreas para exploração variam de 11 a 40 anos para a maioria dos países, ficando a produção concentrada entre os países do Oriente Médio e Rússia. A tabela 1 apresenta as reservas provadas de petróleo no final de 2005(BP, 2006). 
Tabela 1 - Reservas provadas de petróleo no mundo.

\begin{tabular}{|c|c|c|c|c|c|c|c|}
\hline & $\begin{array}{c}\text { Final } \\
\text { de }\end{array}$ & $\begin{array}{c}\text { Final } \\
\text { de }\end{array}$ & $\begin{array}{c}\text { Final } \\
\text { de }\end{array}$ & Final $d$ & 2005 & & Anos \\
\hline & $\begin{array}{c}1985 \\
\text { Bilhões } \\
\text { de } \\
\text { barris }\end{array}$ & $\begin{array}{c}1995 \\
\text { Bilhões } \\
\text { de } \\
\text { barris }\end{array}$ & $\begin{array}{c}2004 \\
\text { Bilhões } \\
\text { de } \\
\text { barris }\end{array}$ & $\begin{array}{l}\text { Bilhões } \\
\text { de } \\
\text { toneladas }\end{array}$ & $\begin{array}{c}\text { Bilhões } \\
\text { de } \\
\text { barris }\end{array}$ & Participação & $\begin{array}{l}\text { Reservas/ } \\
\text { Produção }\end{array}$ \\
\hline $\begin{array}{c}\text { América } \\
\text { do } \\
\text { Norte }\end{array}$ & 101,5 & 89,0 & 60,6 & 7,8 & 59,5 & $5,0 \%$ & 11,9 \\
\hline $\begin{array}{c}\text { América } \\
\text { Central } \\
\text { e Sul }\end{array}$ & 62,9 & 83,8 & 103,0 & 14,8 & 103,5 & $8,6 \%$ & 40,7 \\
\hline $\begin{array}{c}\text { Europa } \\
\mathrm{e}\end{array}$ & 78,6 & 81,5 & 138,7 & 19,2 & 140,5 & $11,7 \%$ & 22,0 \\
\hline $\begin{array}{l}\text { Eurásia } \\
\text { Oriente } \\
\text { Médio }\end{array}$ & 431,3 & 661,5 & 738,2 & 101,2 & 742,7 & $61,9 \%$ & 81,0 \\
\hline África & 57,0 & 72,0 & 113,8 & 15,2 & 114,3 & $9,5 \%$ & 31,8 \\
\hline \multirow{2}{*}{$\begin{array}{c}\text { Ásia e } \\
\text { Pacífico }\end{array}$} & 39,1 & 39,2 & 39,8 & 5,4 & 40,2 & $3,4 \%$ & 13,8 \\
\hline & 770,4 & 1027,0 & 1194,1 & 163,6 & 1200,7 & $100,0 \%$ & \\
\hline
\end{tabular}

Fonte: BP , 2006.

Apesar de existir, por partes de alguns setores e organizações, o discurso que novas regiões produtoras de petróleo e gás natural provavelmente serão descobertas e novas tecnologias de prospecção, seja em águas profundas ou em petróleo betuminoso, serão desenvolvidas a fim de abastecer e repor as quantidades exigidas no mercado mundial observa-se que tal medida não é concretizada. Pode-se observar a evolução e estimativas das descobertas de campos petrolíferos para o período de 1930 a 2050 na Figura 10 (CAMPBELL, 2006).

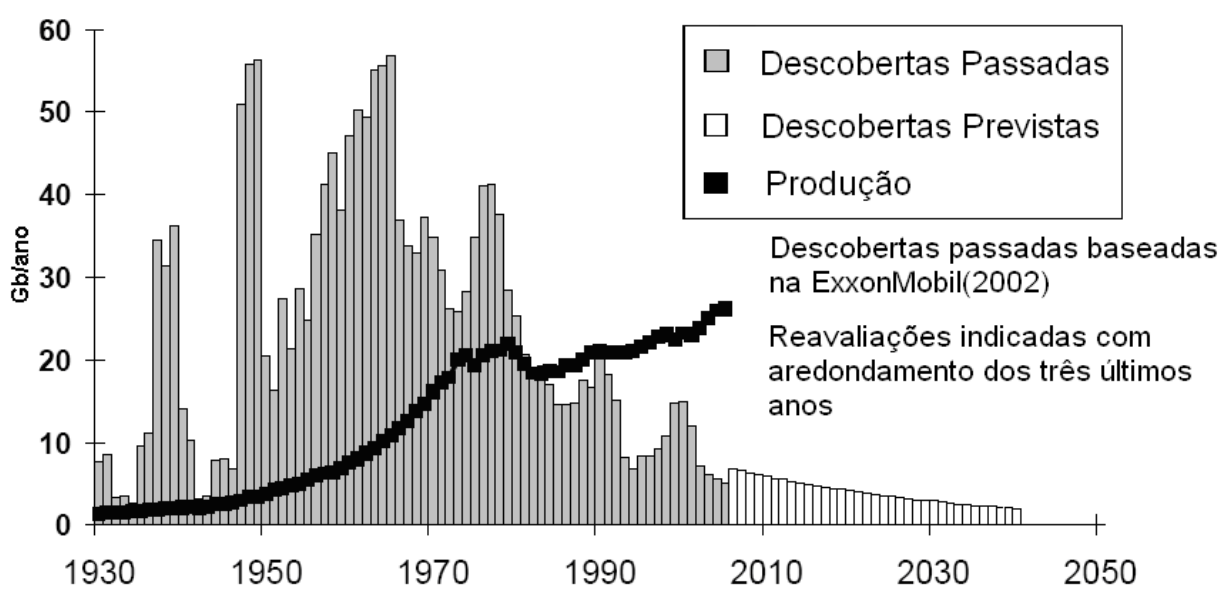

Figura 10 - Curva de Crescimento das Descobertas. Fonte: (Campbell, C.J., 2006) 
Os efeitos na diminuição das reservas mundiais de petróleo convencional de fácil prospeç̧ão obrigam a procura em locais de difícil acesso ou de tecnologia de alto custo como: águas profundas, regiões geladas e petróleo impregnado em areias oleosas. Os preços praticados junto aos mercados mundiais não refletem muitas vezes o verdadeiro custo de produção, uma vez que em muitas regiões, a exemplo do Oriente Médio, o custo é muito inferior ao praticado nas bolsas. Pode-se observar a evolução do preço do petróleo em relação ao período de 1997 a 2006 na Figura 11, com fator de correção aplicado ao dólar.

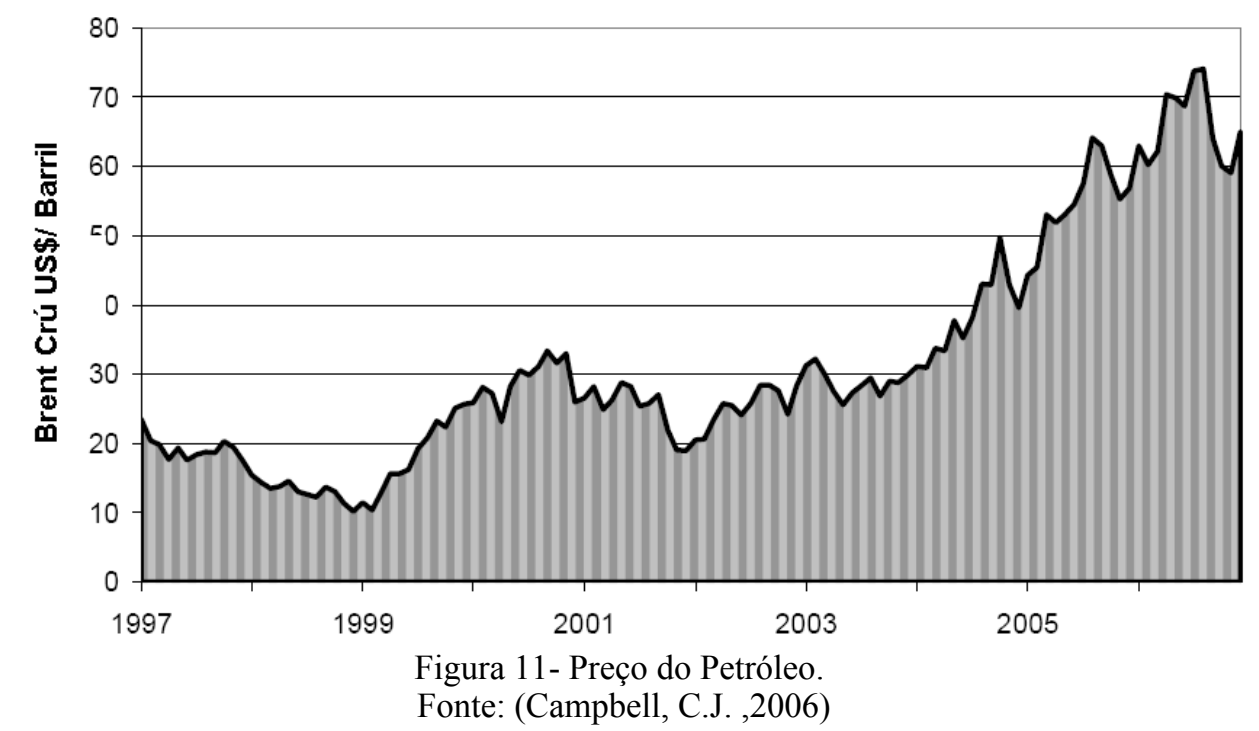

A necessidade, por parte da indústria dos paises desenvolvidos, de uma fonte alternativa ao petróleo, busca no carvão, cujas reservas dos Estados Unidos são as maiores no mundo, recursos para provimento de gás e combustíveis líquidos. Porém o impacto da liberação de enormes quantidades de dióxido de carbono $\left(\mathrm{CO}_{2}\right)$ e outros gases, chamados de gases de efeito estufa da atmosfera, provoca reações climáticas sentidas em várias regiões do planeta. As médias de temperatura registradas mostram que a elevação acentuou-se após o início do século XX, sendo verificado nos últimos anos os mais elevados índices de variações na média das temperaturas em ambos os hemisférios, sendo no hemisfério norte mais expressiva, conforme apresentado na Figura 12 (NASA GISS, 2006). 


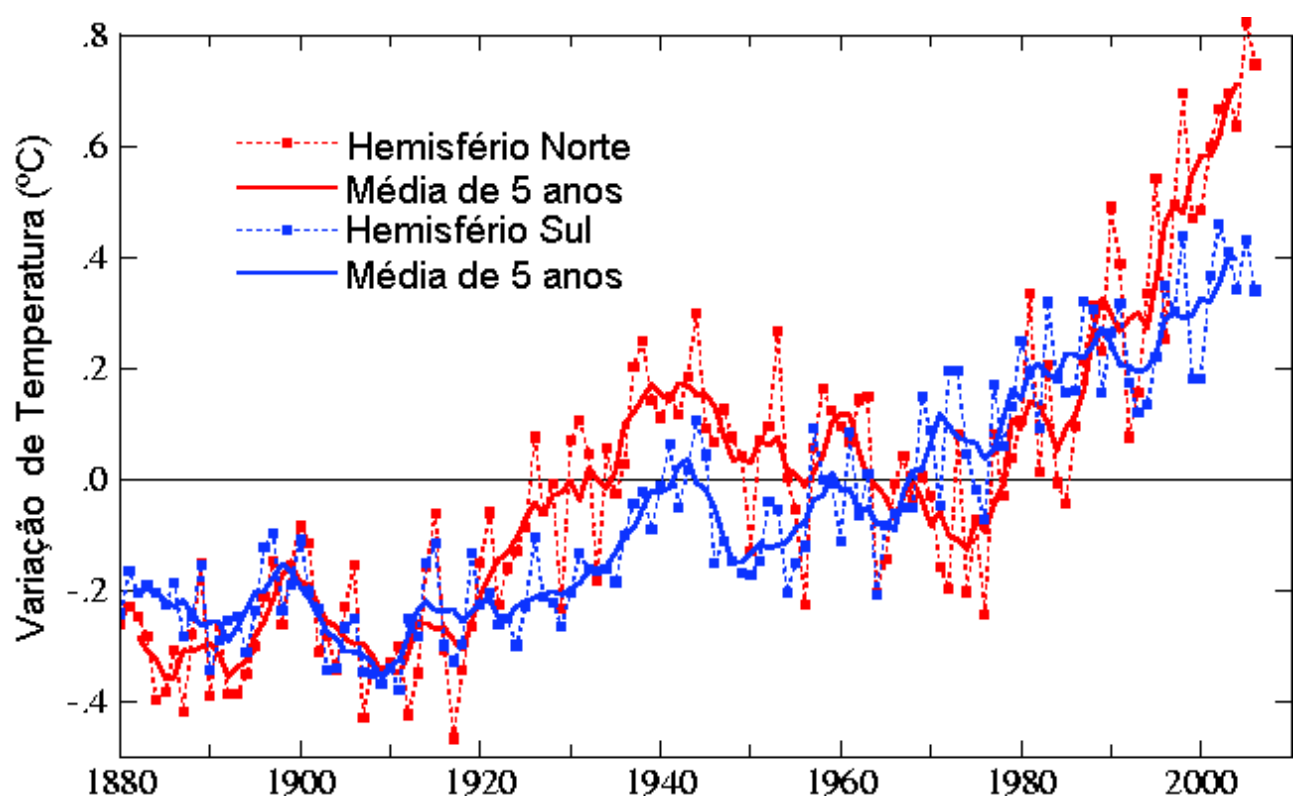

Figura12 - Alterações das Temperaturas Médias nos Hemisférios. Fonte: (NASA GISS, 2006)

Deste cenário surge novamente o etanol, agora mais amadurecido e cujo uso é exemplo para o mundo. No Brasil vê-se o surgimento de uma nova tecnologia, que estabelece um novo parâmetro ao consumidor, o carro tipo Flex, veículo com motor equipado com recursos eletrônicos, gerenciados por computador, que possibilitam ao motor funcionar com qualquer proporção de combustível entre álcool e gasolina com componentes cujos materiais são mais resistentes à corrosão e adequados a esta mistura. A possibilidade de escolha no abastecimento trouxe ao consumidor mais segurança na utilização do álcool, uma vez que a melhor relação custo-benefício era a chave motivacional, não colocando o proprietário do veículo preso a um determinado produto. A introdução sofreu grande aceitação no mercado sendo a produção destes veículos elevada mês a mês chegando à ordem de $70 \%$ dos carros produzidos em dezembro de 2005 serem Flex (ANFAVEA, 2005).

De acordo com o presidente americano George W. Bush (Folha de São Paulo, 2006), "Os carros brasileiros usam uma tecnologia que permite que funcionem tanto com gasolina quanto com álcool. O papel de governos como o nosso é incentivar esse tipo de inovação, de forma a nos tornar menos dependentes de energia importada". A imagem do Brasil na utilização do etanol agora começa a repercutir nos EUA, União Européia, Ásia e Oceania.

O protocolo de Quioto estabelece metas de controle de emissões em países industrializados, visando à redução, até 2012, dos níveis de dióxido de carbono em pelo 
menos 5\% dos praticados em 1990. Esta meta varia de um para outro signatário. O protocolo entrou em vigor em 16 de fevereiro de 2005, assinado por 141 países, sendo trinta destes industrializados. Os EUA recusaram-se a aderir ao protocolo alegando que as metas especificadas prejudicariam a economia de seu país (Folha de São Paulo, 2005). Para o cumprimento destas metas, alguns países, entre eles o Japão, necessitam encontrar alternativas para sua efetivação. Uma das possíveis soluções é a adição de etanol à gasolina. Vários países estão testando em seus veículos, misturas para a viabilidade de utilização.

Alguns países estão se espelhando no programa brasileiro para produzir e utilizar etanol em mistura a gasolina. São eles: EUA, Índia, Suécia, Paraguai, China, Venezuela, Colômbia, Austrália, Tailândia, Canadá e Peru. Isso faz com que o mercado mundial para o etanol se concretize e possibilitando a exportação de parte da produção nacional.

Hoje a infra-estrutura logística de exportação de álcool tem condição de embarcar cerca de 2,5 bilhões de litros/ano. A partir do fechamento de novos contratos, a Petrobras poderá se equipar, fazendo saltar a capacidade exportadora total do país para 12 bilhões de litro ao ano até 2010 (MDIC, 2006).

O Brasil produziu, na safra 2005/2006, a quantidade de 386,6 milhões de toneladas de cana-de-açúcar suficientes para a produção de 16 bilhões de litros de etanol e 25,8 milhões de toneladas de açúcar (UNICA, 2006). A Figura 13 mostra a evolução da produção de cana-de-açúcar da safra 1990/1991 a 2005/2006.

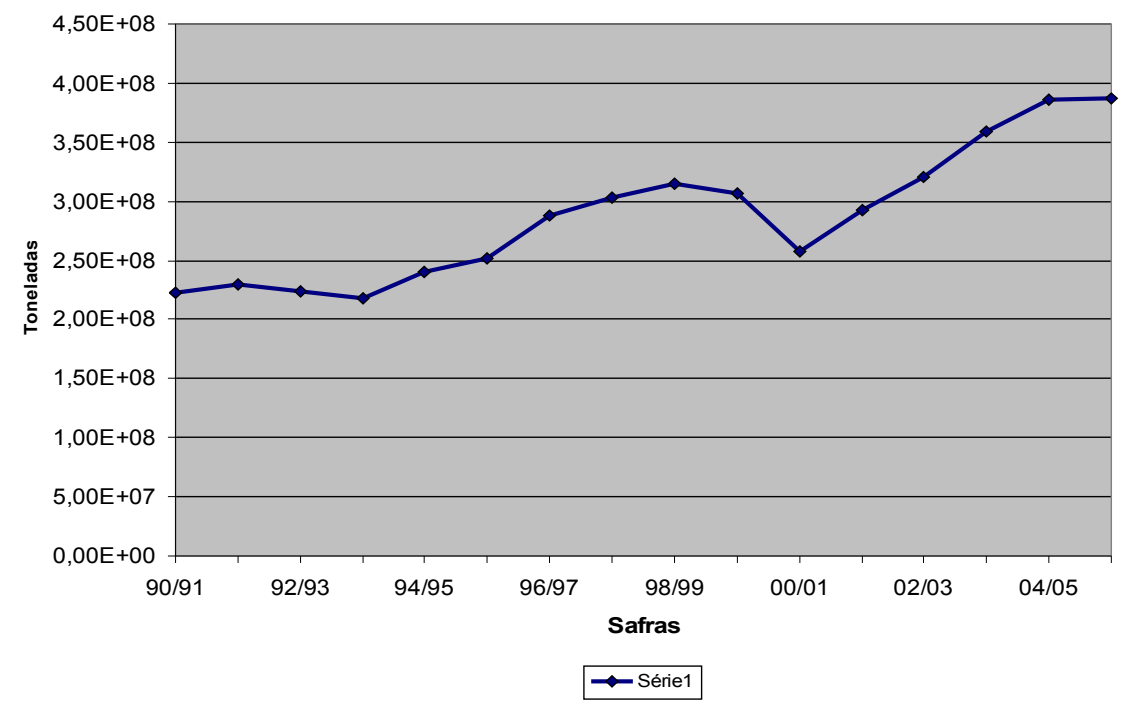

Figura 13 - Safra de cana - Brasil de 90/91 a 05/06 Fonte: (UNICA,2006) 
De acordo com CARVALHO (UNICA, 2006): “O Brasil tem 1\% e os Estados Unidos outro $1 \%$ do conjunto da gasolina comercializado no mundo. São 30 bilhões de litros em mais de um trilhão, volume incapaz de sequer causar cócegas no gigante chamado petróleo". A tabela 2 apresenta a produção mundial de etanol em 2004 e 2005.

Tabela 2 - PRODUÇÃO MUNDIAL ANUAL DE ETANOL EM $10^{6}$ LITROS

\begin{tabular}{|c|c|c|c|c|c|}
\hline Ano & 2004 & 2005 & & 2004 & 2005 \\
\hline País & \multicolumn{2}{|c|}{ Volume } & País & \multicolumn{2}{|c|}{ Volume } \\
\hline Brasil & 15095 & 15995 & Itália & 151 & 151 \\
\hline EUA & 13337 & 16135 & Austrália & 125 & 125 \\
\hline China & 3648 & 3799 & Japão & 117 & 114 \\
\hline Índia & 1748 & 1699 & Paquistão & 98 & 91 \\
\hline França & 829 & 908 & Suécia & 98 & 110 \\
\hline Rússia & 749 & 749 & Filipinas & 83 & 83 \\
\hline África do Sul & 416 & 390 & Coréia do Sul & 83 & 64 \\
\hline Reino Unido & 401 & 348 & Guatemala & 64 & 64 \\
\hline Arábia Saudita & 299 & 121 & Cuba & 61 & 45 \\
\hline Espanha & 299 & 352 & Equador & 45 & 14 \\
\hline Tailândia & 280 & 299 & México & 34 & 45 \\
\hline Alemanha & 269 & 431 & Nicarágua & 30 & 26 \\
\hline Ucrânia & 250 & 246 & Maurício & 23 & 11 \\
\hline Canadá & 231 & 231 & Zimbábue & 23 & 19 \\
\hline Polônia & 201 & 219 & Quênia & 11 & 15 \\
\hline Indonésia & 167 & 170 & Suazilândia & 11 & 11 \\
\hline \multirow[t]{2}{*}{ Argentina } & 159 & 167 & Outros & 1279 & 2687 \\
\hline & & & Total & 40755 & 45977 \\
\hline
\end{tabular}

Fonte: F.O.Licht, 2006. Adaptada pelo autor. 
Diante de tal cenário ficam as questões:

- Interessa ao Brasil abastecer este mercado? Será capaz?

- A cana-de-açúcar é a única alternativa para o Brasil?

- Existe articulação suficiente entre gestores de energia e agricultores?

- Crescimento do mercado externo permitirá que nossas empresas continuem sendo $100 \%$ nacionais?

\subsection{Cenários futuros}

A utilização do etanol, diante da perspectiva atual, sinaliza para um crescente volume de utilização mundial. A possibilidade de produção de etanol a partir de diversas fontes de matéria-prima, dá condições para que cada país adote o sistema que mais lhe convier, tendo como parâmetro a cultura mais adequada ao seu clima e solo. $\mathrm{O}$ desenvolvimento e domínio desta tecnologia acontecem em médio e longo prazo, dependendo do estágio tecnológico já existente em cada país. Como exemplo, pode-se apresentar os Estados Unidos que em um curto espaço de tempo, conseguiu desenvolver e ampliar o parque de produção de etanol, alcançando, junto ao Brasil, a posição de maior produtor mundial do combustível. As justificativas para a adoção são as mais diversas, desde o argumento estratégico, visando à segurança nacional, frente à dependência energética, à de evitar o aquecimento global.

A União Européia também articula a adoção, mais acentuada, do etanol como combustível, facilitando, via financiamento, a conversão de usinas produtoras de açúcar para a produção de etanol, porém a competitividade aos preços praticados atualmente só será possível quando o preço do petróleo alcançar 90 euros/barril (CCE, 2006).

Vários países vêem, na possibilidade de produzir o etanol como combustível alternativo, a chance de deixar de fazer parte do grupo de subdesenvolvido. Países africanos, asiáticos, latinos americanos lançam-se a produção do etanol para fornecimento aos países do primeiro mundo.

O mundo procura por novas fontes energéticas a fim de prover as futuras gerações. A expectativa é que mais cedo ou mais tarde o uso de hidrocarbonetos 
cessará. Por outro lado, a busca de usos como o hidrogênio e fusão nuclear ainda esbarram em desenvolvimento tecnológico. A geração de recursos solares, eólicos e hidroelétricos é estacionária e o aproveitamento permite ser local ou através da transmissão via rede de distribuição.

O etanol, hoje utilizado em motores de combustão interna, apresenta-se como o combustível ideal para utilização das células a combustível, sendo tecnologia desenvolvida e já testada com hidrogênio na geração de energia elétrica em automóveis e equipamentos eletrônicos (Fuelcells, 2006).

As projeções de utilização do etanol, seja puro ou como aditivo à gasolina, já alcançam volumes consideráveis. Conforme a agência de consultoria F.O.Licht (2006) o mercado tende a expansão, como mostrado na tabela 3.

Tabela 3 - Projeção da produção mundial de álcool (em bilhões de litros)

\begin{tabular}{c|c}
\hline Ano & Volume (10 litros) \\
\hline 2004 & 41 \\
2005 & 50 \\
$2006(1)$ & 54 \\
$2007(1)$ & 58 \\
$2008(1)$ & 61 \\
$2009(1)$ & 66 \\
$2010(1)$ & 70 \\
\hline
\end{tabular}

(1) Estimativa

Fonte: F.O.Licht, 2006

Observa-se que a projeção estima quase a duplicação do uso de etanol em apenas seis anos, sendo assim uma ótima oportunidade de negócio, não só para o Brasil, mas para todos os países que dispuserem de matéria-prima, tecnologia e investimento no setor. Barreiras comerciais são outros fatores que existirão a fim de possibilitar o amadurecimento e desenvolvimento de mercados e tecnologias desses países. 
Podem ser verificados na tabela 4 os percentuais estabelecidos por alguns países para a mistura do etanol à gasolina, sendo que a perspectiva é de aumento para os próximos anos.

Tabela 4 - Uso de Etanol Misturado à Gasolina.

\begin{tabular}{c|cc}
\hline Até 5\% & Entre 5\% e 10\% & Mais de 10\% \\
\hline União Européia, Índia, & EUA, Canadá, China, & Brasil, Paraguai, Malásia, \\
Filipinas, Equador, & Tailândia, Austrália, Peru, & EUA (E85), Canadá (E85), \\
Bolívia, & Colômbia, Venezuela, & Suécia (E85), Reino Unido \\
& República Dominicana, & (E85). \\
Vietnã, Japão (E3 ou & África do Sul, Etiópia, & \\
ETBE7). & Nigéria, Coréia do Sul(?) & \\
\hline
\end{tabular}

Fonte: F.O.Licht, 2006 


\section{MATÉRIA-PRIMA PARA O ETANOL}

Os Estados Unidos, que há menos de dez anos não cogitava a utilização do etanol como combustível, divide atualmente com o Brasil as primeiras posições entre os maiores produtores do mundo: aumenta sua capacidade produtora visando um plano para diminuir a sua dependência energética em relação aos combustíveis fósseis e prepara-se para a utilização de tal combustível em novas tecnologias em geração de energia. Verifica-se que algo está sendo modificado em relação ao uso do etanol mundialmente. Seu uso, até pouco tempo, limitava-se ao setor de química fina, na área de farmácia e perfumaria. Por ter preço elevado no mercado mundial dificilmente era utilizado como combustível. No mundo verifica-se a utilização de diversos tipos de materiais para a geração da bioenergia, na sua maioria materiais derivados de plantas, seja na forma de raiz, grão, caule, folha ou galho. Fora do Brasil, todo etanol produzido com base em biomassa é denominado bioetanol, para que se faça a diferenciação dos produzidos a partir do carvão e até mesmo do petróleo, casos da África do Sul e Arábia Saudita respectivamente.

O Brasil, sendo um país continental, com variações qualitativas de solo, clima, recursos hídricos, possui condições inigualáveis para a produção agrícola, seja para a utilização como alimento seja para a produção de matéria-prima à geração de energia.

Conforme dados do Ministério da Agricultura, Pecuária e Abastecimento (MAPA), o Brasil consta com "pelo menos 90 milhões de terras agricultáveis ainda não utilizadas, o Brasil pode aumentar em, no mínimo, três vezes sua atual produção de grãos, saltando dos atuais 123,2 milhões para 367,2 milhões de toneladas. Esse volume, porém, poderá ser ainda maior, considerando-se que 30\% dos 220 milhões de hectares hoje ocupados por pastagens". Diante de tal afirmação o desafio de melhor utilizar estas áreas fica lançado. A análise de experiências e processos realizados em várias regiões do mundo e principalmente no Brasil faz parte dos próximos parágrafos. 


\subsection{A cana-de-açúcar}

A história da cana-de-açúcar no Brasil começa logo no início de sua colonização, trazida das Ilhas Canárias é introduzido por Martim Affonso de Souza, em 1532 em São Vicente no litoral paulista, mas foi na região nordeste do Brasil que se desenvolveu a economia do açúcar, abastecendo o mercado europeu (Machado, 2001).

A cana-de-açúcar é uma planta perene que necessita para bom desenvolvimento uma precipitação pluviométrica de 1.200 a $1.300 \mathrm{~mm}$ anuais, bem distribuídos, e que o período chuvoso coincida com os meses iniciais do desenvolvimento da planta. A temperatura ótima para o desenvolvimento da planta oscila entre 20 a $24^{\circ} \mathrm{C}$, não tolerando a geada. Pode ser cultivada em diversos tipos de solo, tanto argiloso como arenoso. Requer solos profundos, com textura média e boa capacidade de retenção de água. A acidez deve situar-se na faixa de $\mathrm{pH}$ 5,5 a 6,5, havendo necessidade de calagem em solos com pH abaixo do limite inferior (Zink et al, 1978).

Existem variações modificadas que são resistentes à variações climáticas, pragas, e com melhor adaptabilidade a solos diferentes, desenvolvidas em instituições publicas e privadas, em 2000, um convênio entre Fundação de Amparo à Pesquisa de São Paulo(FAPESP) e a COPERSUCAR foi concluído o seqüenciamento genético da cana-de-açúcar com vista a melhoria genética das mesmas (FAPESP, 2000).

O Brasil, hoje o principal produtor de cana-de-açúcar do mundo, colheu na safra 2006/2007 o equivalente a 471,2 milhões de toneladas (CONAB, 2006), sendo esta dividida para a produção de açúcar e álcool. Devido aos recursos e técnicas desenvolvidas nos últimos trinta anos, o índice de produtividade no seguimento agroindustrial alcançou níveis fantásticos, consegue-se colher em um hectare aproximadamente 80 toneladas de cana e a partir de uma tonelada a produção média de $142 \mathrm{~kg}$ de açúcar ou a fabricação de 80 litros de álcool. Estes números também elevam o País a ser o principal produtor de açúcar (29,7 milhões de toneladas) e álcool (17,8 bilhões de litros) do mundo (CONAB, 2006). Para se alcançar estes níveis de produção o setor sucroalcooleiro desenvolveu melhorias na manipulação agrícola, dos tipos de cana e processos químicos. Dentro de uma usina de açúcar podem existir dois processos distintos de produção, um para o açúcar e outro para o álcool. Ambos iniciam-se com a determinação do momento certo do corte da cana, etapa esta determinada por avaliação da quantidade de açúcar acumulada (açúcares redutores totais, ART). Na maioria das plantações o corte é realizado manualmente, após as queimadas. Porém, com 
perspectivas de aproveitamento da palha na geração de energia e por determinação legal (Lei $\mathrm{n}^{\mathrm{o}} 11.241 / 02$ - Estado de São Paulo e regulamentado pelo Decreto Estadual No 47.700 de 11 março de 2003) o processo vem sendo alterado com utilização de equipamentos desenvolvidos para este fim. Hoje, cerca de 30\% da produção nacional já é realizada sem o uso de queimadas (UNICA, 2005). Após a colheita, a cana é transportada.

O material chega às usinas onde é lavado, picotado, desfibrado e enviado para as moendas, onde é extraído o caldo para dar início ao processo de fabricação do açúcar ou álcool. O bagaço, durante a moagem, sofre um processo de embebição (acréscimo de água) formando o caldo misto. O bagaço após o processo é enviado para alimentação das caldeiras com o objetivo de gerar vapor e energia elétrica.

O caldo, chamado primário, segue para o processo de clarificação (sulfitação e caleação), aquecimento, filtragem. O caldo misto (ou secundário) segue para o processo de filtragem. Neste processo tem-se a formação da torta de filtro, componente rico em nutrientes para fertilização do solo. Seguindo o processo, o caldo é aquecido e pode ser destinado à produção de açúcar ou de álcool.

A produção do etanol dá-se com a preparação do mosto, seguida da fermentação do caldo clarificado. É do processo de destilação do produto fermentado que se obtém o vinhoto (resíduo), também conhecido como vinhaça, substância rica em nutrientes como nitrogênio, fósforo e potássio e o etanol. Quando lançado em rios o vinhoto provoca o efeito chamado de eutroficação. Sua proporção em relação ao volume de álcool produzido varia de 10 a 15 vezes a do etanol. Apresenta DBO elevadíssima: varia de 30.000 a $40.000 \mathrm{mg} / \mathrm{l}$ (BHANDARI et. al.; 1979), um litro de vinhoto equivale a produção de dejetos orgânicos humanos de 1,4 pessoas (MENEZES, 1980). A modernização do setor sucroalcooleiro considera os materiais de fim de processo não mais como simples resíduos, mas como matéria-prima para a adubação, através da fertirrigação. A utilização dos resíduos tem sido testada na produção de biogás, ração animal, produção de fungos para fermentação, material de construção e em incineração para caldeiras (Copersucar, 1998).

$\mathrm{Na}$ figura 14 é apresentado o fluxograma genérico de uma usina de produção de açúcar e álcool, observado nas usinas que realização ambos os processos na utilização da cana-de-açúcar. 


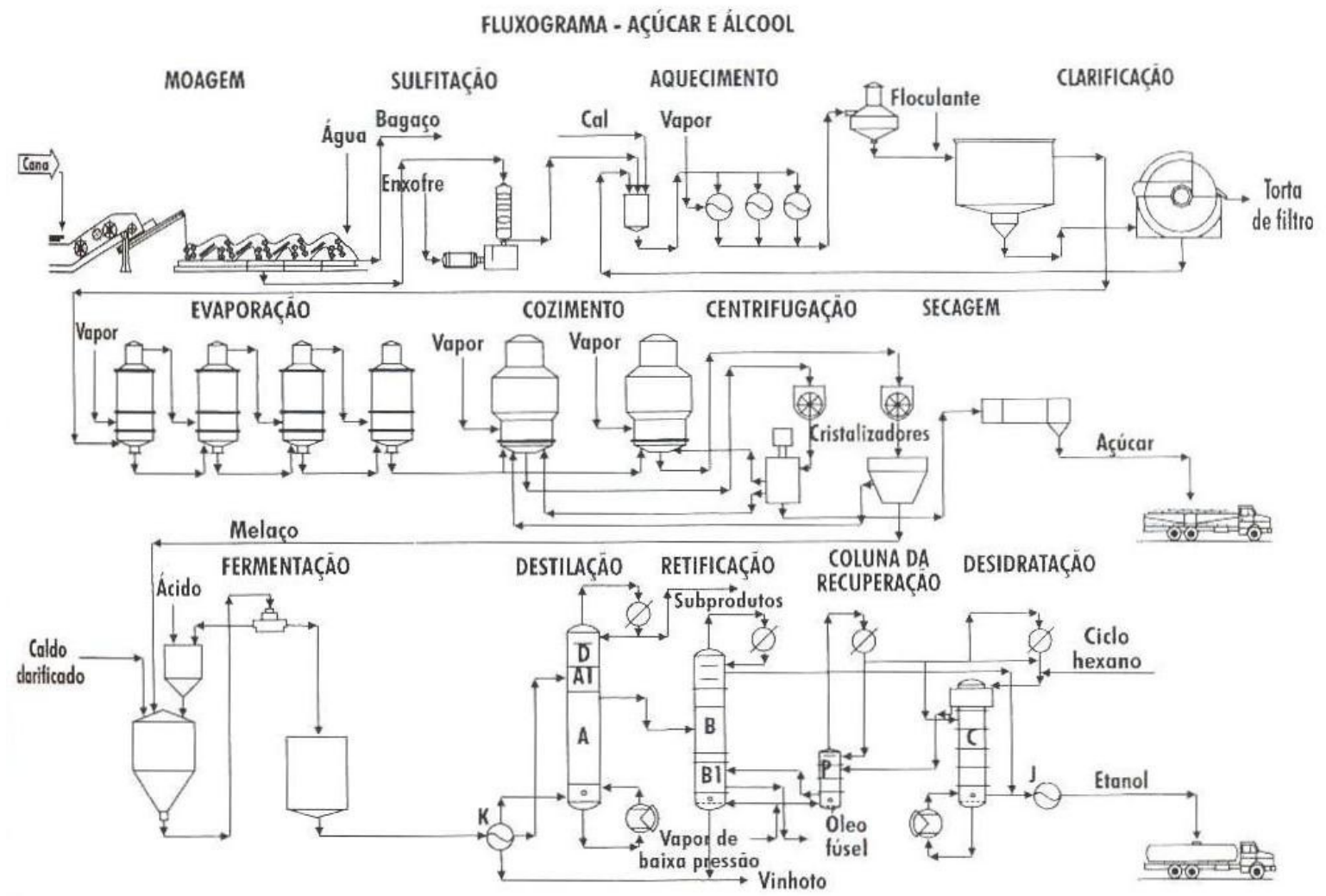

Figura 14 - Fluxograma de produção de açúcar e álcool. Fonte: (Macedo, 2005).

\subsection{Outras fontes possíveis}

A produção mundial de etanol não se restringe a utilização da cana-de-açúcar, outras fontes de biomassa são aproveitadas em diversos países. Pode-se destacar o milho, a beterraba branca (açucareira), o sorgo sacarino, o trigo, a mandioca (cassava) e resíduos florestais. Nos últimos dez anos países como EUA, França, Espanha, Suécia e China vêm se destacando na utilização dessas matérias-primas para o desenvolvimento de seus programas de fontes alternativas de energia. Cada país procura a melhor solução tendo em conta questões de clima e oferta de produto. Nos EUA a existência de uma cultura de plantio do milho propiciou a produção de 13,4 bilhões de litros em 2004 (BERG, 2004). Na tabela 5 são apresentadas as matérias-primas utilizadas para produção de etanol por países que já começam a adotá-lo. 
Tabela 5 - Países e Matérias-Primas Adotadas.

\begin{tabular}{c|c}
\hline Matéria-Prima & Países \\
\hline Cana-de-açúcar & Brasil, Índia, Austrália, Peru, Argentina e \\
Milho & Euérica Central. \\
Beterraba Açucareira & França, Alemanana, Espanha. \\
Mandioca (Cassava) & Tailândia \\
Trigo & China \\
Restos Florestais & Suécia. \\
\hline Sorgo & China, Países Africanos, Índia. \\
\hline
\end{tabular}

Fonte: F.O. Licht, 2003

O Brasil pode, devido a sua grande variação territorial e diversificação climática, usufruir de diversas culturas, muitas delas com características para a produção de etanol.

$\mathrm{Na}$ tabela 6 são apresentados alguns produtos utilizados para a produção de álcool etílico em países com condições diversas do Brasil, seus diferentes níveis de produtividade e os respectivos preços alcançados no ciclo de produção.

Tabela 6 - Comparativo: Matérias-Primas Para Produção de Etanol.

\begin{tabular}{l|lcccc}
\hline País & Matéria-prima & $\begin{array}{c}\text { Produção média } \\
\text { ton/ha }\end{array}$ & Volume 1/ton. & Volume 1/ha & $\begin{array}{c}\text { Preço } \\
\text { US cents/1 }\end{array}$ \\
\hline Brasil & cana-de-açúcar & 75 & 75 & 5625 & 15 \\
EUA & milho & 8 & 380 & 3000 & 24 \\
França & beterraba & 70 & 100 & 7000 & 25 \\
\hline
\end{tabular}

Fonte: F.O.Licht, 2003 
Para cada clima existe uma cultura que melhor se adapta e em conseqüência gera maior produtividade na sua exploração. Na tabela 7 é apresentado algumas culturas selecionadas por alguns países e seu respectivo processo de produção.

Tabela 7 - Matéria-Prima, Clima e Processo Produtivo.

\begin{tabular}{l|ll}
\hline \multicolumn{1}{c|}{ Matéria-Prima } & \multicolumn{1}{|c}{ Clima } & \multicolumn{1}{c}{ Processo Produtivo } \\
\hline $\begin{array}{l}\text { Cana-de-açúcar } \\
\text { Sorgo }\end{array}$ & $\begin{array}{l}\text { Tropical } \\
\text { Tropical e Temperado }\end{array}$ & $\begin{array}{l}\text { Fermentação } \\
\text { (Colmos) Fermentação }\end{array}$ \\
Mandioca (Cassava) & Tropicais & $\begin{array}{l}\text { (Grão) Cozimento e Fermentação } \\
\text { Cozimento e Fermentação }\end{array}$ \\
Milho & Tropical e Temperado & (Grão) Cozimento e Fermentação \\
Beterraba Branca & Temperado & Cozimento e Fermentação \\
\hline Batata Doce & Temperadas & Cozimento e Fermentação \\
\hline Fonte: MENEZES, 1980. &
\end{tabular}

Entre os anos de 1970 e 1990, muitas pesquisas foram realizadas no Brasil tendo como matéria-prima o sorgo, a mandioca e a batata doce. Estas apresentaram bons rendimentos, sendo obtidos resultados satisfatórios, conforme apresenta a tabela 8 (MENEZES, 1980). Porém, o desenvolvimento destas culturas sempre esbarrou em critérios de preço e tecnológico, como no caso da mandioca relatado por Shwartzmam em A História do Instituto Nacional de Tecnologia, na qual faz referências às condições estabelecidas para a construção da Usina de Álcool de Curvelo (SHWARTZMAN, 1997), uma vez que as suas produções apresentam processos característicos e rentabilidades diferentes da cana-de-açúcar.

Tabela 8 - Estimativa de produção de etanol.

\begin{tabular}{c|cc}
\hline Matéria-Prima & Litros/tonelada & Litros por hectare \\
\hline Mandioca & 180 & 2.160 \\
Sorgo sacarino & 55 & 1925 \\
BATATA-DOCE & 125 & 1250 \\
Milho & 385 & 580 \\
Babaçu & 80 & 200 \\
Cana & 67 & 3015 \\
\hline
\end{tabular}

Fonte: MENEZES, 1980 
As tabelas 6, 7 e 8 mostram que existe potencial para desenvolvimento da produção de etanol com outras fontes, porém as mesmas deverão passar por um período de aprendizado como aconteceu com a cana que apresentou uma produção média de 80 toneladas por hectare e uma extração de 80 litros por tonelada na safra de 2004/2005(UNICA, 2006). A mudança de enfoque junto aos produtores é necessária, havendo participação de cooperativas produtivas para o alcance do objetivo. Este processo acontece nos EUA, onde o setor agropecuário está aproveitando as oportunidades, para se tornar também produtor energético.

\subsection{Sorgo sacarino.}

Devido as grandes variações climáticas existentes no Brasil não é possível o cultivo da cana-de-açúcar em todas as regiões com o mesmo índice de produtividade encontrado nas regiões centro-sul e nordeste. Como alternativa encontra-se o sorgo sacarino (Sorghum bicolor L. Moench), que será apresentado, tendo em vista suas características diferenciais quanto ao clima e solo.

O sorgo, uma gramínea cultivada em várias regiões do planeta, é o quinto cereal mais cultivado no mundo, ficando atrás do trigo, arroz, milho e cevada. Sua origem remonta da África há 5000 anos, na região do Sudão-Etiopia, espalhando-se pelas tribos do leste africano durante os últimos mil anos, devido à difusão da cultura. A introdução das primeiras sementes em território do continente americano deu-se através dos escravos levados para lá. O cultivo nos EUA deu-se por volta de 1850 em terras texanas, de onde se originou os tipos Rio e Roma, as quais são utilizadas para a geração de novos tipos híbridos (MILLER, 1977). Conforme a FAO, $440.000 \mathrm{~km}^{2}$ foram destinados para a produção de sorgo em todo mundo em 2004, entre muitas variedades existentes. O principal uso é de forragem, sendo também muito utilizado como alimento humano na África e Ásia. Sua principal característica é de ser resistente à falta de água e de se desenvolver em solos com características salinas. Na tabela 9 pode-se verificar as principais variedades e usos para o sorgo. 
Tabela 9 - Diferentes tipos de sorgo quanto à forma de utilização.

\begin{tabular}{ccl}
\hline Tipo de Sorgo & Produto & \multicolumn{1}{c}{ Utilização } \\
\hline Granífero & Grão & Substituto do milho na alimentação animal - rações \\
& & balanceadas (bovinos, suínos e aves), utilização do \\
& & restolho. \\
& Alimentação humana - uso da farinha. \\
& Na industrialização de produtos: amido, cera, cer- \\
& veja, óleo, etc. \\
Forrageiro & Biomassa & Corte, silagem e feno. \\
Vassoura & Panículo & Vassouras, escovas e ornamentação - tem uso res- \\
& trito e localizado. \\
Sacarino & Colmo e & Frutose, sacarose e álcool. \\
& Grão & \\
\hline
\end{tabular}

Fonte: Olivetti \& Camargo, 1997.

O uso do sorgo sacarino, uma das espécies existentes, devido ao alto teor de açúcar em seus colmos, está sendo empregado em alguns países na produção de etanol. (ICRISAT, 2006).

Pouco conhecido no Brasil, começou a ser estudado já entre os anos de 1940 e 1950 em Campinas. Sua difusão deu-se a partir da década de 1970, principalmente como substituto do milho durante a entressafra. Desde então a sua produção está vinculada principalmente às empresas produtoras de sementes. Com o choque do petróleo nas décadas de 1970 e 1980 se iniciou o estudo para a obtenção de etanol em complemento à cana-de-açúcar. O sorgo foi estudado por diversos centros através e foi principalmente no Instituto de Zootecnia, Nova Odessa - SP, onde pesquisadores da Embrapa (TEIXEIRA, at al, 1997), realizaram, com sementes do BR505 cedidas pelo Centro Nacional de Pesquisa de Milho e Sorgo, de Sete Lagoas - MG, cultivares cujo objetivo era de compará-los aos da cana-de-açúcar cultivados em condições idênticas de solo e clima.

Os resultados obtidos demonstraram a possibilidade de utilização do sorgo sacarino como fonte de matéria-prima para o etanol em complemento à cultura da canade-açúcar no período da entressafra. A tabela 10 apresenta os resultados comparativos 
dos rendimentos de natureza agroindustrial obtidos de colmos de sorgo sacarino Br505 e de cana-de-açúcar nos anos agrícola de 1987/88 e 1988/89.

Aspectos do sorgo sacarino (FAO, 2006):

- O seu cultivo é realizado a partir de sementes,

- O ciclo vegetativo é de 90 a 130 dias,

- A altura para colheita de 3,0 a 5,0 m,

- O manejo pode ser totalmente mecanizado semelhante ao milho,

- Custos de produção semelhantes ao milho,

- Há a geração de grãos para alimentação animal,

- O bagaço também pode servir como fonte de energia para as caldeiras no processo de produção,

- O processo de obtenção do etanol é semelhante ao da cana,

- Em geral o sorgo apresenta alta resistência hídrica, resistindo mais que o milho e a cana,

- Demonstra-se adaptar bem a solos com salinidade acima do normal.

Tabela 9 - Rendimentos de natureza agroindustrial obtidos de colmos de sorgo sacarino Br505 e de cana-de-açúcar nos anos agrícola de 1987/88 e 1988/89.

\begin{tabular}{|c|c|c|}
\hline & $\begin{array}{c}\text { Ano agrícola } \\
1987 / 88\end{array}$ & $\begin{array}{c}\text { Ano agrícola } \\
1988 / 89\end{array}$ \\
\hline \multicolumn{3}{|l|}{ Sorgo Sacarino } \\
\hline $\mathrm{N}^{\circ}$ de plantas/ha & 138.564 & 82.710 \\
\hline Rendimento de colmos/ha (kg) & 48.497 & 48.485 \\
\hline Rendimento em grăos/ha (kg) & 2.875 & 4.166 \\
\hline ART dos colmos (\%) & 9,71 & 9,56 \\
\hline ART/ton de colmos $(\mathrm{kg})$ & 97,1 & 94,60 \\
\hline $\begin{array}{l}\text { Álcool etilico a } 100^{\circ} \mathrm{GL} \text {, } \\
\text { teórico em litros/ton de colmos }\end{array}$ & 62,88 & 61,91 \\
\hline $\begin{array}{l}\text { Álcool etflico a } 100^{\circ} \mathrm{GL} \text {, } \\
\text { eficiência } 53 \% \text { sobre ART , } \\
\text { em litros/ton colmos }\end{array}$ & 53,61 & 52,78 \\
\hline \multicolumn{3}{|l|}{ Cana de açúcar } \\
\hline ART dos colmos (\%) & 10,33 & 10,65 \\
\hline ART/ton de colmos $(\mathrm{kg})$ & 103,3 & 106,5 \\
\hline $\begin{array}{l}\text { Álcool etilico a } 100^{\circ} \mathrm{GL} \text {, } \\
\text { teórico em litros/ton de colmos }\end{array}$ & 66,89 & 68,96 \\
\hline $\begin{array}{l}\text { Álcool etilico a } 100^{\circ} \mathrm{GL} \text {, } \\
\text { eficiência } 53 \% \text { sobre ART, em } \\
\text { litros/tonelada colmos }\end{array}$ & 54,70 & 56,60 \\
\hline
\end{tabular}

Fonte: TEIXEIRA et al., 1997. 
O sorgo, por se tratar de uma cultura de ciclo vegetativo curto, de 90 a 130 dias, apresenta-se ideal para o complemento na produção de etanol durante o período de entressafra da cana-de-açúcar, cujo ciclo é de ano e meio ou anual, nas grandes usinas de etanol, permitindo ampliar o período de uso em três meses. Também apresenta características interressantes para as propriedades médias e pequenas, as quais possibilitam uma maior rotação de culturas e produção do próprio combustível.

Projetos com uso adequado da terra e recursos agrícolas começam a despontar com a utilização do sorgo, chamados MUAIs, Mini-Usina de Álcool Integrada (ORTEGA, 2003), possibilitam junto à cana e outras culturas a geração de energia elétrica e combustível para o empreendimento dando sustentabilidade nas atividades pecuárias e agrícolas. Porém o cultivo do sorgo no Brasil se restringe ao uso forrageiro e em alguns lugares ao uso artesanal com o tipo vassoura. A cultura do sorgo é praticamente inexistente quando o seu uso visa fins energéticos.

Enquanto as perspectivas brasileiras desde as décadas de 1970 e 1980, chegando ao século XXI, demonstram potencial, mas com pouco interesse e divulgação, observase que outros países já vêem no sorgo sacarino uma alternativa real para o domínio completo da produção e uso do etanol. China, Índia, UE, EUA, e vários países da África são exemplos.

Na China ao longo dos rios Amarelo e Yangtze, vinte províncias com condições inadequadas para o cultivo da cana-de-açúcar, em terras de baixa produtividade, alta salinidade e já degradadas, vêem no sorgo a chance de deixar de importar dois milhões de toneladas de açúcar por ano e diminuir a dependência energética em relação aos combustíveis fosseis. Estudos, que iniciaram na década de 1980, são realizados, em conjunto com a FAO e vários cientistas, na elaboração e concretização da produção de etanol a partir do sorgo. Através de pesquisas e melhoramentos genéticos foram analisados seis tipos de sorgo, visando a melhor adaptação ao clima e condições de solo.

Foram analisados os meios produtivos, armazenamento, aproveitamento energético, adequação com uso de energia solar, bem como os postos de trabalho, adequação de equipamento e meios de multiplicação dos conhecimentos para os agricultores de outras regiões. Nos projetos foram observados que o consumo de água por parte da cultura do sorgo é um terço da necessária para a cana e que são necessários somente $4,5 \mathrm{~kg}$ de sementes para um hectare contra 4,5 a 6,0 toneladas para a mesma área. A massa verde obtida varia de $50 \mathrm{a} 60$ t/ ha. $\mathrm{O}$ volume de etanol processado com o 
sorgo (colmos + grãos) propicia uma produção anual de 6000 a 7000 1/ha.ano, em duas colheitas (FAO, 2002). A figura 15 apresenta a planta e a figura 16 o caule do sorgo sacarino da variedade Shennong $\mathrm{N}^{\mathrm{o}} .2$, híbrido desenvolvido pelos chineses em cooperação com a FAO.
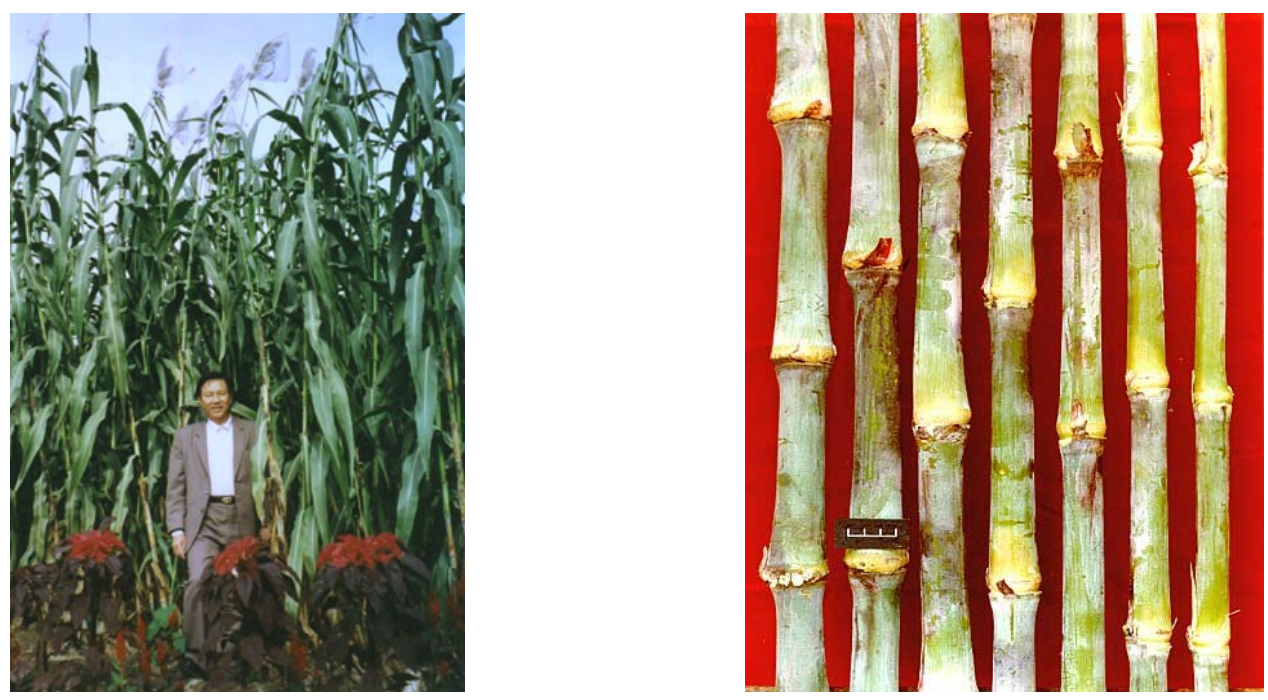

Figuras 15, 16 - O sorgo sacarino alcançando 5m de altura e os respectivos colmos. Fonte: (ecoport.org, 2006).

As figuras 17 e 18 apresentam respectivamente as sementes no topo da planta e após serem colhidas, observando-se neste caso uma a semelhança com o milho. $\mathrm{O}$ grão pode ser aproveitado na obtenção do etanol em processo similar ao praticado na produção do etanol de milho.
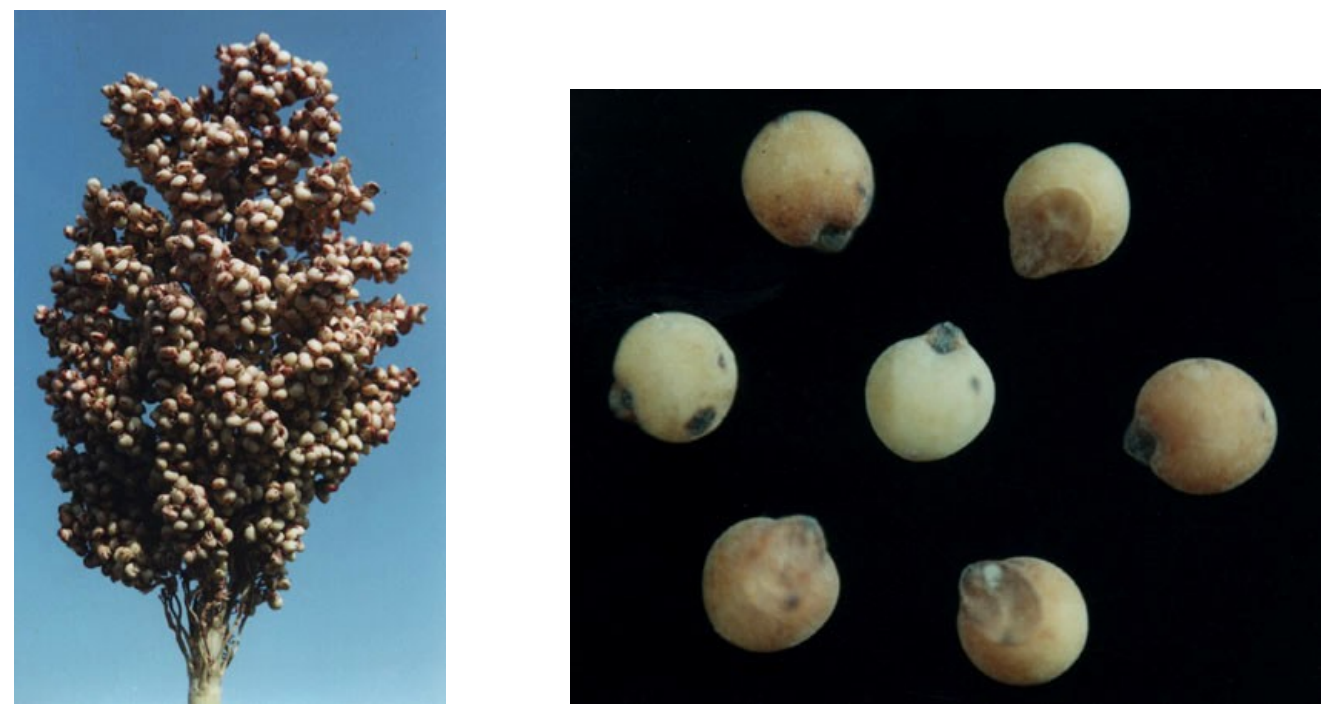

Figuras 17 e 18 - Grãos no topo dos colmos e os grãos assemelhados ao milho. Fonte: (ecoport.org, 2006) 
Na Índia o programa de produção de sorgo sacarino visa à desconcentração dos grandes centros e proporcionar a geração de fontes energéticas sustentáveis e acessíveis à população. $\mathrm{O}$ etanol é utilizado como combustível em fornos domésticos e na iluminação residencial em substituição à lenha e ao querosene oriundo do petróleo.

Conforme Rajvanshi, do Nimbkar Agricultural Research Institute (NARI, 2001), Phaltan, Maharashtra, Índia, o grande aumento no consumo de combustíveis por parte da população está provocando uma preocupação generalizada uma vez que são gastos 18 bilhões de dólares na compra de petróleo por ano. A busca por bens como automóveis, motos e outros artigos pelas gerações mais novas apontam para um gasto ainda maior. A busca por fontes alternativas e principalmente sustentáveis está no foco da instituição juntamente com o Massachusetts Institute of Technology (MIT) dos Estados Unidos.

Em projetos piloto do NARI, são obtidos anualmente por hectare, duas colheitas gerando de 2500 a 3000 litros de etanol a $95 \%$ v/v, 2 a 3 toneladas de grãos para farinha e 15 a 20 toneladas de bagaço para ração ou como combustível para gaseificação.

Nas figuras 19, 20 e 21 são apresentados equipamentos desenvolvidos pelo NARI para a obtenção e uso do etanol junto às pequenas comunidades.

Projeto semelhante encontra-se em desenvolvimento na Zâmbia com o apoio do NARI.

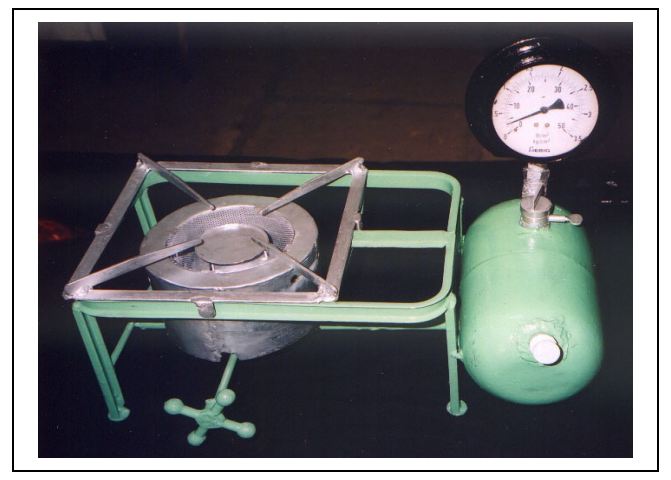

Figura 19 - Fogão a etanol com chama controlada. Fonte: (NARI, 2001) 


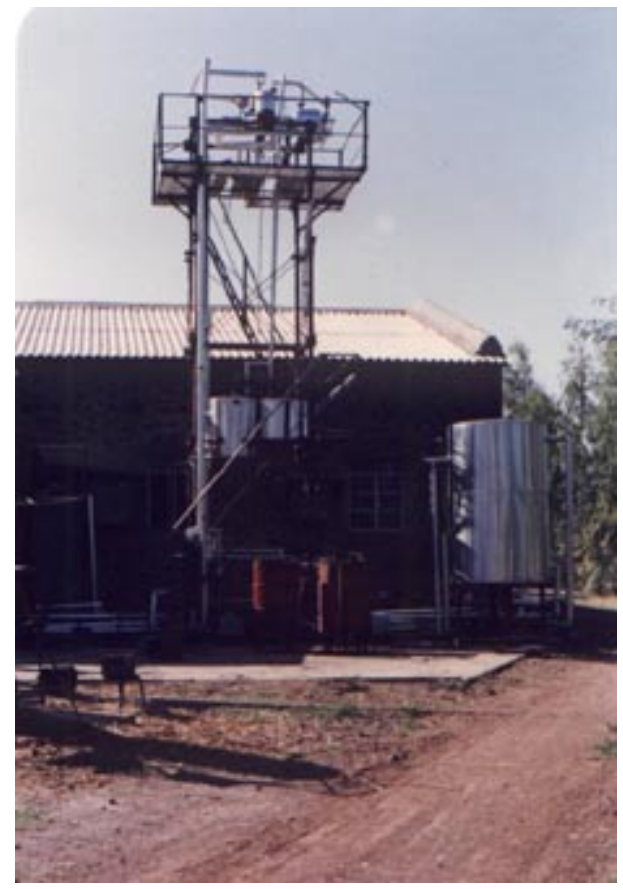

Figura 20 - Destilação solar de etanol a partir de sorgo. Capacidade diária de 50 litros. Fonte: (NARI, 2001).

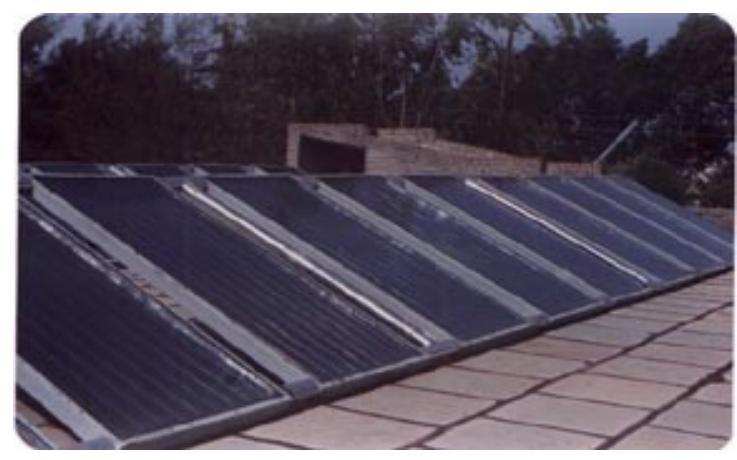

Figura 21 - Painel solar de $32 \mathrm{~m}^{2}$ utilizado na destilação do etanol. Fonte: (NARI, 2001).

A Europa realiza projetos para a produção do etanol a partir do sorgo em diversos paises tais como: Grécia, Espanha, Reino Unido, Portugal, Itália, Alemanha visando o cumprimento da diretriz da comunidade européia de redução na utilização de combustíveis fósseis (LAMNET, 2002).

Os Estados Unidos nos últimos anos, com as leis de restrição do uso de MTBE como aditivo oxigenante à gasolina em diversos estados, vê a utilização do etanol em curva ascendente. Tal crescimento está estimulando o uso cada vez maior do milho, sua principal fonte de matéria-prima na produção do etanol e como conseqüência a redução 
dos estoques e aumento dos preços (RFA, 2006). O governo dos EUA, através de impostos na importação do etanol e subsídios aos agricultores incentiva a produção de biocombustíveis a partir de cereais. Tal procedimento é criticado por muitos pesquisadores devido ao balanço energético do processo envolvido. Estima-se que na produção de etanol a partir do milho utilize mais energia do que gera (PATZEK, 2006). Dentro deste cenário o sorgo, que já é cultivado e pesquisado desde 1850, surge como cultura para fornecimento de grãos ricos e açúcares.

A perspectiva de utilização dos dois processos, grãos e caule, semelhantes aos utilizados pelo milho e a cana, provocou uma corrida para a implantação de novos projetos pelos estados mais propícios a esta cultura. Várias usinas em construção já prevêem a utilização do sorgo sacarino na obtenção do etanol (RFA, 2006).

A passagem de uma cultura para outra também implica em aprendizado e adaptação. O maior problema está na necessidade de se processar rapidamente grandes quantidades de colmos, pois a sua oxidação é rápida, tal qual acontece com a cana, envolvendo então um problema logístico para processamento. Quando da utilização do milho como matéria-prima o mesmo é armazenado em silos e processado paulatinamente conforme a necessidade, não havendo perdas (ANDERSON, 2006). 


\section{LOGÍSTICA DE DISTRIBUIÇÃO E PREÇO}

Brasil, país de dimensões continentais 8,5 milhões de $\mathrm{km}^{2}, 7,3$ mil $\mathrm{km}$ de costas banhadas pelo Oceano Atlântico e 15,7 mil km de fronteiras com paises vizinhos, 5.560 municípios em 26 estados (IBGE, 2001) tem uma população estimada em 188 milhões de pessoas, com uma frota de veículos leves e automóveis de passeio estimado em 21,28 milhões de unidades. A frota de veículos leves e automóveis movidos a álcool e bicombustíveis, somando ao acumulo de 2000 a 2005, atingiu o volume de 2,91 milhões de unidades o que representa $13,7 \%$ do total. A produção de veículos bicombustível/álcool alcançou o total de 659.167 unidades no período de janeiro a junho de 2006. Este volume, somado ao acumulado de 2000-2005, resulta no total de 3,579 milhões de unidades ou 15,9\% do total. A produção de veículos bicombustíveis cresce a cada ano, permitindo estimar que em poucos anos a produção de automóveis e veículos leves atinja a meta de $100 \%$ com tecnologia flexível (ANFAVEA, 2006).

A busca de novas fronteiras agrícolas, para suprimento desta frota e atender a demanda externa de etanol, implica em necessidade de ampliar a produção em regiões cada vez mais distantes dos principais centros consumidores. Vê-se a ampliação do cultivo de cana-de-açúcar pelo noroeste paulista, em terras utilizadas principalmente para a pecuária, sul e sudoeste de Minas Gerais, sul de Goiás e Mato Grosso do Sul e início do cultivo em terras do Tocantins (UNICA, 2006). O modal de transporte para o combustível no Brasil em \%, apresentado na tabela 11, é formatado da seguinte maneira (Sant’Anna, 2006):

Tabela 11 - Modal de Transporte para o Combustível no Brasil em \%.

\begin{tabular}{|c|c|c|c|c|c|}
\hline Origem & Destino & Navio & Duto & Ferroviário & Rodoviário \\
\hline Refinarias e USINAS & Bases Primárias & 48 & 41 & - & 11 \\
\hline Bases Primárias & Bases Secundárias & 8 & - & 61 & 31 \\
\hline Bases Secundárias & Mercado & - & - & - & 100 \\
\hline
\end{tabular}

Fonte: Sant'Anna, 2006. 
Na figura 22, pode-se observar a malha adotada atualmente para o transporte de combustíveis pelo Brasil paras as regiões centro-sul, nordeste e norte (Sant`Anna, 2006).

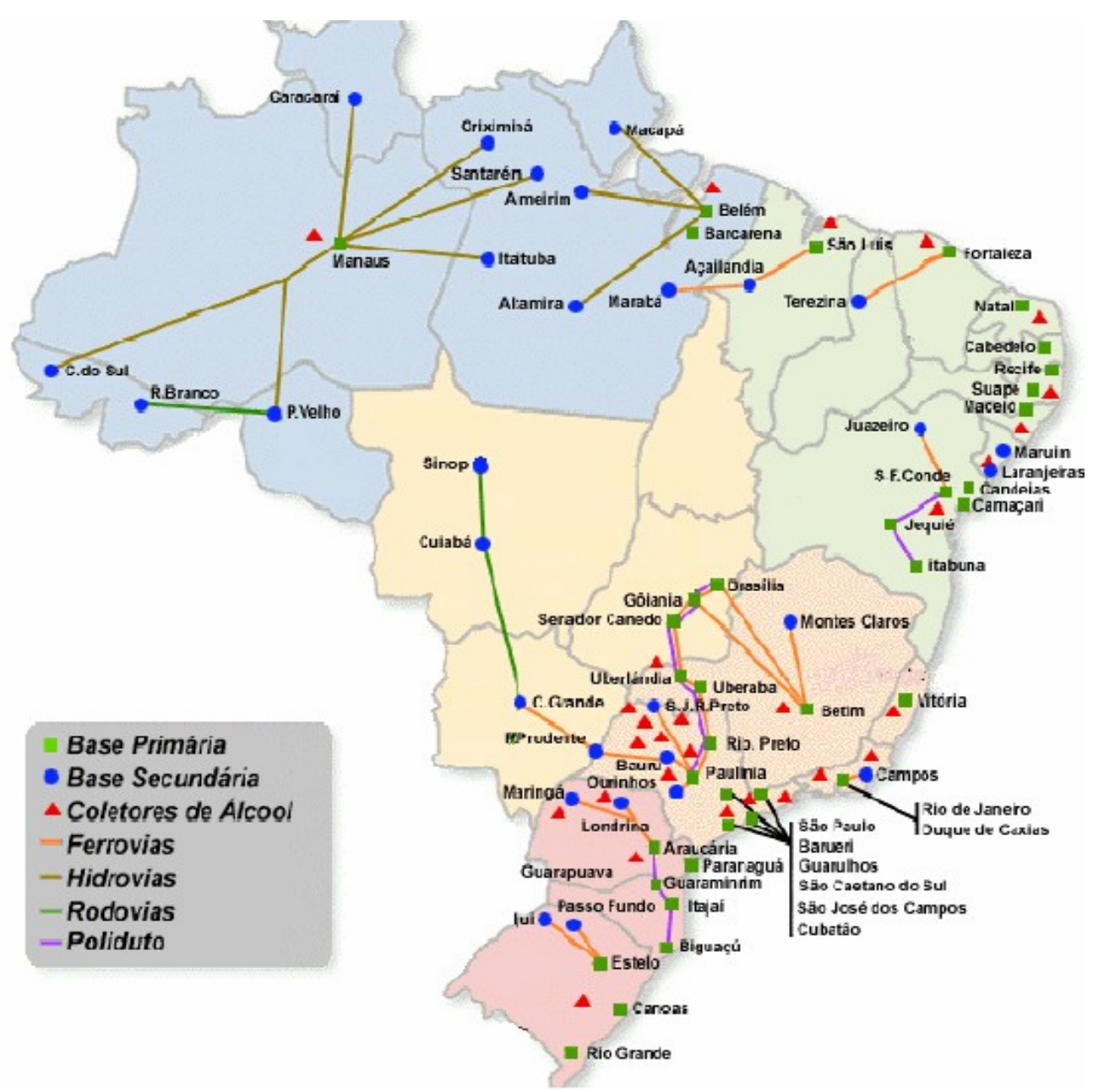

Figura 22 - Malha de distribuição existente no Brasil para transporte de combustíveis.

Fonte: (Sant`Anna, 2006).

O suprimento para estas regiões implica no uso de recursos de logística que acabam impactando no preço para o consumidor. O etanol, que na sua maioria é produzido no centro-sul, é enviado de trem ou caminhão tanque aos grandes centros e então, distribuído para outras regiões. Existem locais em que o álcool chega a ter o seu valor próximo ao aplicado à gasolina por questões de transporte, armazenamento e produção.

Visando um mercado externo de etanol em crescimento a Transpetro, subsidiaria de logística da Petrobrás já estuda a ampliação e modernização dos meios utilizados 
para transporte do etanol. Na figura 10 se observa os novos trajetos a serem executados para um melhor fluxo, conforme a Transpetro até 2012,

[...] Os investimentos do Sistema Petrobras em etanol podem chegar a US\$ 600 milhões, divididos em quatro fases, sempre relacionados ao aumento da produção de álcool e dos contratos firmados no exterior para o consumo do produto. O primeiro projeto é a adequação do duto de Guararema ao Rio de Janeiro. O segundo, a construção de um duto interligando a Refinaria de Paulínia ao Terminal de Guararema. O terceiro projeto prevê a instalação de terminais e de um sistema de barcaças na hidrovia Tietê-Paraná. As barcaças levarão derivados de petróleo ao CentroOeste e trarão etanol para a exportação. Já o quarto projeto consiste na construção de um duto na faixa do Oleoduto São Paulo-Brasília. Todos esses investimentos têm como objetivo elevar a movimentação de etanol dos atuais 2.600 mil m3/ano para 4 milhões de m3/ano em 2008. Estão previstas ainda a utilização integrada de trens, barcaças, dutos, caminhões e navios, consolidando a Transpetro como uma empresa multimodal. Para Marcelino Guedes, diretor de Terminais e Oleodutos, "o grande desafio é colocar a logística brasileira em condições de competitividade internacional. Este não é um projeto da Transpetro, não é um projeto do Sistema Petrobras. É um projeto do Brasil". O Terminal Aquaviário de Paranaguá também receberá infra-estrutura para o etanol, assim como o Terminal de Maceió, que terá sua tancagem ampliada. Navios do Programa de Modernização e Expansão da Frota também poderão ser utilizados para a exportação do etanol brasileiro. Charles Labrunie, gerente de Novos Negócios, afirma que o Sistema Petrobras tem diante de si a oportunidade de tornar o setor produtor de álcool brasileiro um importante cliente e parceiro. "Ao oferecer uma solução segura, competitiva, de alta confiabilidade e com garantia da preservação da qualidade do etanol, abre-se um novo mercado" (Transpetro, 2006).

Na figura 23 são apresentados os projetos da Transpetro para a exportação de etanol na região centro-sul. 


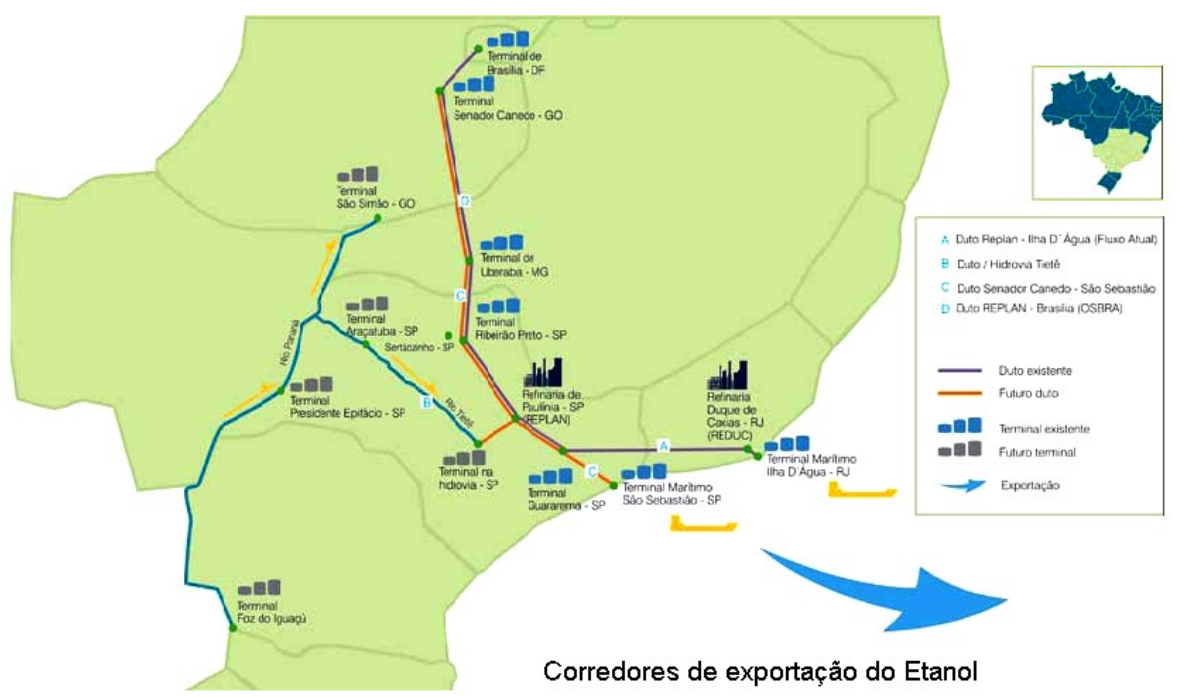

Figura 23 - Novos trajetos planejados pela Transpetro para exportação do Etanol. Fonte: (Transpetro, 2006).

Sem estes avanços logísticos dificilmente o Brasil poderá garantir maiores volumes de etanol aos clientes internacionais, colocando em risco todo projeto desenhado por agricultores e produtores ligados ao mercado de etanol. 


\section{PROCESSOS PRODUTIVOS}

Os processos atuais de produção do etanol se dividem basicamente em dois: o primeiro na utilização da fermentação direta dos açúcares existentes nas matériasprimas, como caldo de cana, melaço, caldo de sorgo; o segundo na fermentação indireta das matérias-primas, que tenham características amiláceas ou celulósicas como grãos de cereais, mandioca, batata. Deste modo o processo completo envolve as seguintes etapas: preparo do substrato, correção do mosto, preparo do inóculo, fermentação e destilação (MENEZES, 1980).

\subsection{Comparativos}

No processo de destilação direta, utilizado no Brasil, a cana é fonte do caldo e energia. Após o preparo da cana, moagem, correção do caldo, filtração e formação do mosto, há o processo de fermentação onde o mosto é submetido à presença de leveduras (Saccharomyces cerevisiae), que realizam uma atividade bioquímica, transformando os açúcares em etanol, gás carbônico e liberando energia. Após, ocorre a separação do etanol na destilação e obtenção, como resíduo de processo, do o vinhoto, hoje utilizado no processo de fertirrigação (MENEZES, 1980).

O processo de fermentação, nos últimos anos obteve ganhos de produtividade devido à melhoria dos usos de leveduras e melhoria de processos (MACEDO, 2005). A tabela 12 apresenta alguns parâmetros e os dados de sua evolução entre os anos de 1977 e 1995.

Tabela 12 - Ganhos de produtividade na fermentação.

\begin{tabular}{|c|c|c|c|}
\hline \multirow{2}{*}{ Parâmetros } & 1977 & \multicolumn{2}{|c|}{1995} \\
\cline { 3 - 4 } & \multirow{2}{*}{ Média } & Média & Melhor valor \\
\hline Rendimento (\%) & 83,0 & 91,2 & 93,0 \\
\hline Tempo de produção (h) & 14,5 & 8,5 & 5,0 \\
\hline Teor de vinho no etanol (\%) & 7,5 & 9,0 & 11,0 \\
\hline Utilização de antiespumante (g/l) & 1,0 & 0,25 & 0,0 \\
\hline
\end{tabular}

Fonte: Macedo, 2005. 
Outro fator a se destacar, ao longo dos anos, é o aproveitamento dos resíduos na geração de energia, seja na produção de vapor para o processo de produção, seja para a co-geração de energia elétrica. Este aproveitamento ultrapassa em muito a energia fóssil utilizada no processo total tomando-se como base as fases de produção agrícola até o processamento final do etanol. Na tabela 13 é apresentado o balanço energético na produção de etanol a partir da cana-de-açúcar no Brasil.

Tabela 13 - Consumo e geração de energia na produção de etanol no Brasil.

\begin{tabular}{c|cc}
\hline Atividade & \multicolumn{2}{|c}{ Energia } \\
\cline { 2 - 3 } & Consumida (kcal/TC) & Gerada (kcal/TC) \\
Produção de Cana-de-açúcar & 45861 & - \\
Produção de Etanol & 9510 & - \\
Etanol Produzido & - & 490100 \\
Bagaço excedente & - & 75600 \\
Total & 55371 & 565700 \\
\hline Razão (Geração / Consumo) & \multicolumn{3}{|c}{10,2} \\
\hline
\end{tabular}

Fonte: MACEDO, 2004.

Já no processo, utilizado na maioria das destilarias dos EUA, segue uma fermentação indireta. A figura 24 apresenta o ciclo produtivo iniciando-se com a embebição do milho em tanques de aço inoxidável, capacidade em geral para aproximadamente 75 toneladas, a temperatura de $50{ }^{\circ} \mathrm{C}$, durante o período de 30 a 40 horas. O grão tem aumentando a sua umidade de 15 a $40 \%$ e seu tamanho em mais de duas vezes. É formada uma solução com a adição de $0,1 \%$ de dióxido de enxofre para evitar a proliferação de bactérias. Enquanto o milho aumenta de volume a acidez do meio aquoso inicia o processo de rompimento das ligações do glúten, dentro do milho, liberando o amido. Logo após o milho é moído a fim de quebrar o germe e outros componentes. No segundo estágio realiza-se a separação do germe através de separadores tipo ciclone. Os germes, contendo aproximadamente $85 \%$ do óleo de milho, são lançados em telas e lavados repetidamente para a remoção do amido deixado na mistura. O óleo é extraído do germe através de processos mecânicos, sendo então refinado e filtrado dando o produto final óleo de milho. O terceiro estágio é realizado a moagem e o peneiramento da pasta de milho. Na seqüência é separado o amido e o 
glúten. A conversão do amido em glicose é realizada no quinto estágio através de um processo químico, com ácidos, ou biológico com enzimas. No sexto estágio se dá a fermentação ou por aminoácidos ou leveduras (CRA, 2006).

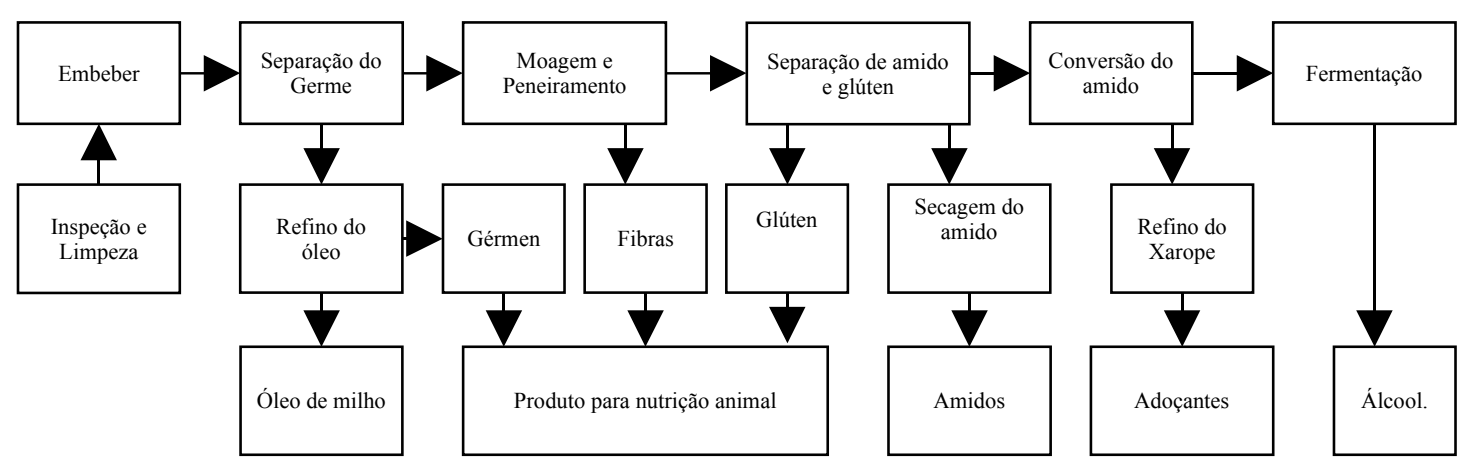

Figura 24 - Ciclo de produção do Etanol a partir do milho.

Fonte: (CRA, 2006).

Sobre o balanço energético, para a produção de etanol a partir do milho, existem muitos estudos e muita controvérsia, segundo Pimentel e Patzek (2005) em seus estudos afirmam que não existe ganho energético e sim uma perda de energia, 1,29: 1. São necessários 29\% a mais do que a energia gerada. Outros autores tais como HILL et al, (2006) calculam que o etanol a partir do milho gera 25\% a mais do que consome. Groode em seus projetos no MIT, afirma que tanto o ganho como a perda pode estar correta, pois a relação sobre os fatores considerados é bem estreita (GROODE, 2006).

\subsection{Modernização}

A perspectiva de elevação do consumo do etanol como combustível ou aditivo oxigenante, está desencadeando uma enorme busca de fontes para produzi-lo. Uma verdadeira corrida em busca de novos processos, que viabilize a obtenção de etanol, a partir de fontes que sejam compostas por celulose. Governos e centros de pesquisa de vários paises procuram a melhoria de projetos já existentes ou na transformação de concepções teóricas em concretas. A perspectiva de se tornarem menos dependentes do petróleo leva países como Japão, Suécia, Espanha, Alemanha, EUA, Canadá e outros a investirem pesadamente na obtenção de etanol a partir da transformação de resíduos vegetais (EIA Bioenergy, 2006). 
Destacam-se os projetos de hidrólise dos materiais celulósicos, processos este que pode caracterizado pela ação de ácidos ou enzimas. No caso de utilização de catalisadores ácidos o processo é denominado Hidrólise Ácida, quando do uso de enzimas recebe a denominação de Hidrólise Enzimática, ambos os processos também podem aparecer em fases distintas de um processo total. Apesar de existirem plantas piloto em vários paises, a perspectiva para construção de uma unidade industrial viável economicamente é de pelo menos dez anos. No Brasil existe uma planta demonstrativa para produção de 5.000 1/dia de etanol, processo este batizado de Dedini Hidrólise Rápida (DHR), a partir do resíduo do bagaço da cana. As perspectivas são de que até 2008 já se possa ter os parâmetros necessários para a construção de uma unidade em escala industrial (ROSSELL, 2006). 


\section{PERSPECTIVA DE PRODUÇÃO MUNDIAL DE ETANOL}

A produção de etanol como combustível para queima, seja puro ou como aditivo, não é a única utilização que se pode dar ao etanol. $\mathrm{O}$ uso como futuro elemento na geração de energia elétrica em células a combustível, equipamentos com eficiência energética superiores aos motores de combustão interna, é uma das possibilidades, outra é a de se estabelecer Pólos Alcoolquímicos, uma vez que existirá um volume razoável para tanto, na elaboração de derivados e subprodutos como: amila, butila, etila , vinila, borrachas sintéticas, PVC, compostos plásticos em substituição a diversos elementos hoje provenientes do petróleo são fatores para a maior utilização do etanol.

Fatos estes que abrem a possibilidade de se produzir em várias regiões, hoje com baixo índice de desenvolvimento, a partir de produtos agrícolas, os volumes necessários de etanol para o futuro. Isto leva, ao longo dos tempos, a uma transferência de tecnologia e riquezas aos povos menos afortunados. A possibilidade de haver monoculturas e concentração de renda também é provável, caberá a cada país a melhor adequação aos seus interreces de progresso e sustentabilidade.

Como a maioria das terras remanescentes para agricultura no mundo se localiza em paises em desenvolvimento e estes se localizam próximo às áreas dos trópicos conclui-se que os futuros fornecedores de energia ao mundo estarão nestas regiões.

Conforme Berg (2004) a produção de etanol, que hoje se concentra basicamente entre EUA e Brasil, tenderá a uma modificação com a inclusão de paises africanos, da Austrália, Índia e outros paises latinos americanos. A figura 25 apresenta o mapa de produção do etanol no mundo em 2003. Pode-se observar que os responsáveis pela produção do etanol a partir de grãos e de culturas produtoras de açúcar (cana e beterraba). 

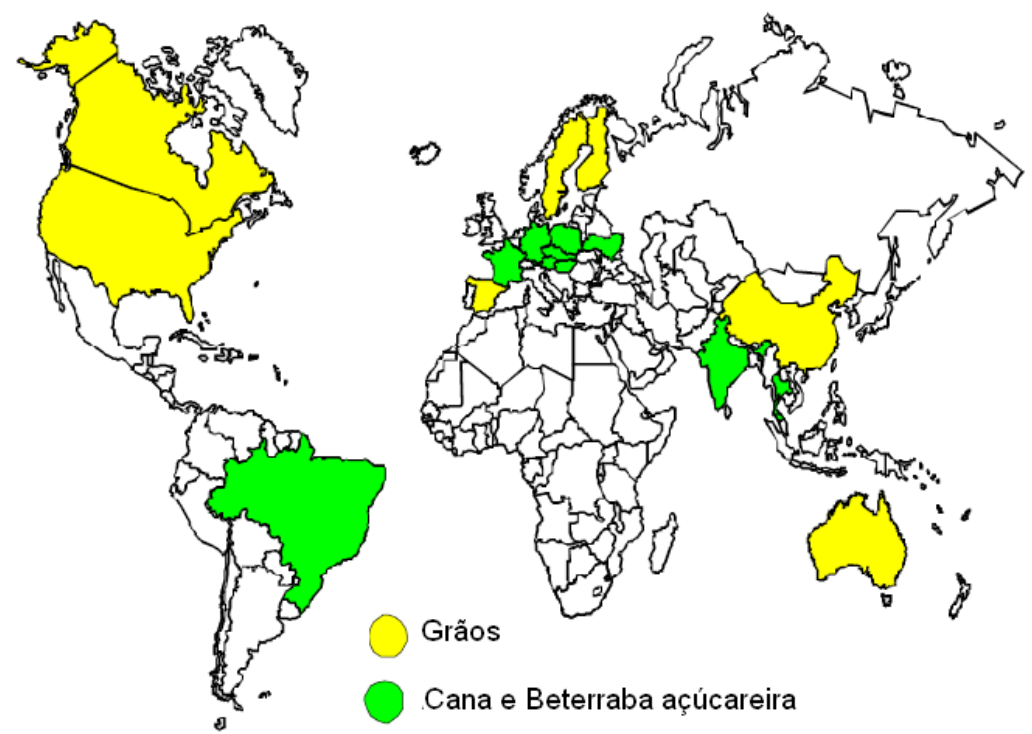

Figura 25 - Etanol no Mundo em 2003.

Fonte: (Berg, 2004)

A adoção de tecnologias mais rentáveis e energeticamente mais favoráveis, como a cana-de-açúcar e o sorgo sacarino, deverá ser adotada por paises que hoje têm a sua produção baseadas em grãos como o caso da Austrália. A China e os EUA deverão aumentar a sua produção de etanol baseado em cana e sorgo, porém será a partir de grãos o seu maior volume. Na figura 26 é mostrado a provável distribuição da produção de etanol em 2013.
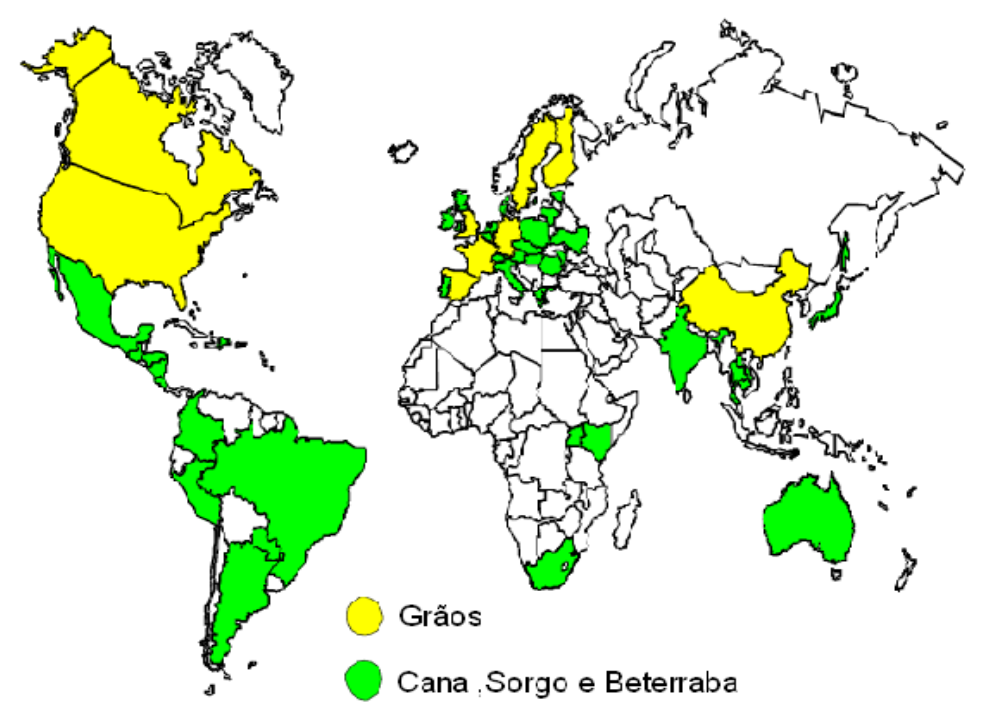

Figura 26 - Etanol no Mundo em 2013.

Fonte: (Berg, 2004). 
A produção mundial de etanol deverá ser dirigida principalmente ao hemisfério norte, Europa, EUA e Ásia, devido às questões ambientais. Na figura 27 é apresentado o fluxo comercial de etanol futuramente.

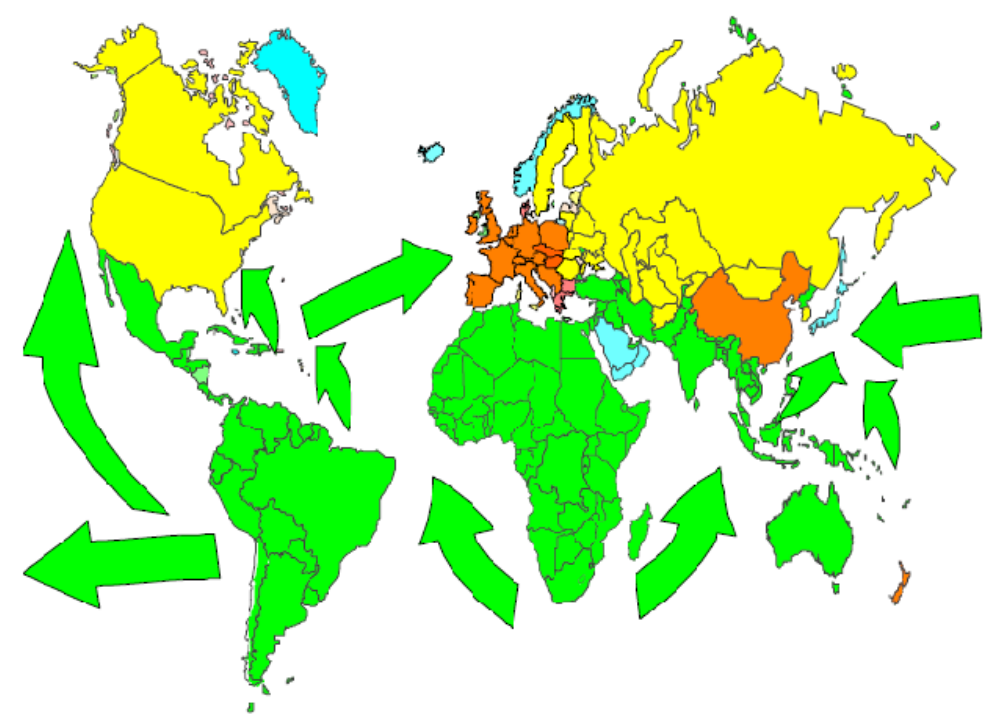

Figura 27 - Comércio Mundial de Etanol no Futuro. Fonte: (Berg, 2004). 


\section{DISCUSSÃO E CONCLUSÕES.}

Diante do exposto nos textos anteriores cabe a tentativa de responder algumas questões fundamentais.

Interessa ao Brasil abastecer este mercado? Será capaz?

No Brasil, país de dimensões continentais, provido de clima equatorial e temperado possibilita o cultivo de enumeras variedades vegetais, cuja área julgada agricultável, segundo o MAPA, 90 milhões de hectares ainda podem ser abertos ao plantio. Existem cerca de 220 milhões de hectares destinados a pastos, também passíveis ao uso da agricultura, porém não são todas próprias para o plantio da cana e não são latifúndios, são propriedades que basicamente possuem lavouras de rotação para o provimento de alimento às pessoas e aos animais. Regiões com pequena capacidade hídrica e terras degradadas podem ter o seu aproveitamento com uso adequado de tecnologia e apoio técnico-científico. A utilização de parte deste potencial para a produção de etanol, seja de cana, sorgo sacarino, mandioca, babaçu já daria condições de se estabelecer volumes consideráveis para o mercado interno e externo. $\mathrm{O}$ fato de que vários paises poderem repetir a mesma receita do Brasil, indica que a existência de um mercado global para o etanol é a prioridade e se deve ter como objetivo a possibilidade de atendimento de frações da necessidade global. A maximização do uso do etanol em novos processos como sua utilização para a produção do biodiesel e a perspectiva de criação de pólos Alcoolquímicos para o processamento de diversos materiais deve motivar a pesquisa para o aproveitamento ainda mais nobre para o etanol.

Conforme apresentado na tabela 1, o petróleo é uma fonte esgotável de energia, assim como o carvão. Suas reservas estão diminuindo e o custo de novos campos produtores aumenta devido à dificuldade de extração e ou processamento.

O uso de hidrocarbonetos aumenta o nível de gases de efeito estufa na atmosfera e a temperatura média do planeta provocando como conseqüência alterações climáticas. A alteração brusca do clima desperta a humanidade para uma nova consciência para com o futuro do planeta. Logo, a crise energética, mesmo que não alardeada, está caracterizada e é na busca das fontes renováveis de energia que se estabelece a esperança de manter o mundo funcionado e habitável para as próximas gerações. 
A cana-de-açúcar é a única alternativa para o Brasil?

Hoje a cana se distingue na produção de etanol como a matéria-prima que estabelece melhores condições de produtividade, porém tal produtividade esta restrita ao uso de determinados solos e condições especiais de clima. Uma vez estabelecido a existência de mercado para o etanol, todo potencial de outras fontes deverá ser aproveitado e isto não vale só para o Brasil, mas para todas as nações. A adoção hoje da produção de etanol a partir de cana, milho, beterraba, sorgo, mandioca (cassava), estabelece um ponto inicial para muitos países. O Brasil passou por este aprendizado na década de 1970 e 1980 desenvolvendo tecnologia de melhores espécies, melhorando tecnicamente os meios produtivos nas usinas, desenvolvendo uma logística de distribuição por todo território nacional, usando de subsídios para este desenvolvimento e retirando-o quando do amadurecimento do setor, etapas estas que foram repletas de tentativas, falhas e muitos acertos. Ainda hoje, no Brasil, a busca por melhoria dos processos é observada nos laboratórios das empresas e universidades. $\mathrm{O}$ desenvolvimento de tecnologia para o aproveitamento da palha da cana na geração de energia, a produção de etanol a partir do bagaço da cana com utilização da hidrólise ácida e enzimática são fatores que possibilitarão o aumento da produção de etanol sem que haja um maior espaço cultivado. Porém, toda esta experiência adquirida e muitas vezes esquecida, não deve ser destinada somente para alavancar processos em países distantes e sim utilizada para desenvolver regiões potenciais existentes no Brasil.

Em congressos internacionais sobre o uso do bioetanol fala-se sobre o uso do sorgo, da cassava, do milho, do trigo e resíduos florestais tendo como referência a cana brasileira. A análise de custos eleva ainda mais a posição do processo brasileiro, uma vez que o balanço energético para a cana libera cerca de oito a dez vezes mais energia do que consome, enquanto o processo utilizado pelos EUA apresenta dados ainda conflitantes. Existem analistas que apregoam ao processo uma taxa positiva entre vinte a vinte oito por cento, enquanto outros estabelecem taxas negativas próximas de vinte por cento, sendo que o mesmo ocorreu nos primórdios do PROALCOOL (MENEZES, 1980).

Existe articulação suficiente entre gestores de energia e agricultores?

A produção de combustíveis a partir de fontes vegetais, em particular a matériasprimas que estabeleçam um conflito de interesses entre a produção de alimento ou combustível, é questão fundamental na articulação das necessidades futuras da 
humanidade. A busca pelo equilíbrio e melhor aproveitamento de recursos deverá fazer parte das negociações entre gestores de energia e agricultores. Hoje se observa que não existe uma resolução holística quando se trata de assuntos ligados ao meio ambiente, à agricultura e à energia. É necessário uma maior troca de informações e que as decisões antecipem os desdobramentos futuros.

O crescimento do mercado externo permitirá que nossas empresas continuem sendo $100 \%$ nacionais?

Economicamente, no atual estágio mundial de produção do etanol, o processo desenvolvido no Brasil é o mais rentável. Porém, devido à própria experiência nacional tal processo poderá passar para as mãos de empresas multinacionais facilmente. A maioria das empresas do setor é de estrutura gerencial familiar, não possuem experiências com implantação de sistemas de sociedades anônimas. Poucas empresas de vários setores da indústria nacional apresentam experiências envolvendo o mercado externo, algumas se aventuram após anos de trabalho e vitórias no mercado doméstico concorrendo com multinacionais. Enquanto a maioria de empresas ligadas ao setor energético, fora do Brasil, são multinacionais com larga experiência no trâmite internacional e jogos políticos. Logo, a possibilidade de vermos nossas empresas, tecnologias desenvolvidas e principalmente nossas terras sendo arrebatadas e gerenciadas por empresas internacionais são enormes. A possibilidade de geração de riqueza existe. Porém, a permanência dela em território nacional depende do trato deliberado entre capital, terra e trabalho e regulamentação para a prática a ser estabelecida.

Com a impossibilidade de se plantar cana em todo o território nacional surge a figura do sorgo sacarino, cultura de ciclo mais curto, cerca de noventa dias, resistente à fadiga hídrica, necessita de $33 \%$ a $50 \%$ a menos da água utilizada para a produção de cana, que poderá ser implantada junto a pequenos e médios produtores na rotação de culturas, uma vez que seu plantio é semelhante ao do milho, podendo ser manual ou mecanizado. Seu cultivo permite a utilização de sementes para o provimento de ração animal e seu caule a produção de etanol e geração de energia elétrica a partir do bagaço, semelhante ao que ocorre com a cana. $\mathrm{O}$ fato de seu ciclo de produção ser curto possibilita a entrada de um maior número de novos produtores descentralizados, viabilizando o fornecimento para pequenas comunidades com menor custo e com geração de empregos na localidade, bem como a formação de cooperativas de produção. 
O etanol, como combustível, já é uma realidade no Brasil e a cada dia será mais presente nas mentes das pessoas em todo o mundo. O uso do veículo Flex, com gerenciamento computadorizado de combustível álcool e gasolina, trouxe uma revitalização no uso do etanol hidratado. A característica de ser menos poluente que a gasolina, contribuir para a diminuição da poluição nos grandes centros, sua produção ser baseada em matérias-primas de fontes sustentáveis, a ajuda na redução do aumento dos gases estufa e tornando a economia menos dependente dos hidrocarbonetos realçou sua importância perante outras nações. Seu exemplo está sendo usado como paradigma em projetos espalhados pelo mundo, mesmo que outras fontes de matéria-prima sejam utilizadas, como em paises da África, Europa, Ásia, Américas e Oceania.

A adição de etanol como oxigenante da gasolina, que muitas vezes foi lembrada em épocas de crise mundial, está sendo implementada em diversos paises visando à redução dos efeitos poluentes e maior independência em relação ao petróleo. Somente este uso cria a possibilidade de um mercado mundial de etanol. A adesão dos EUA ao uso do etanol, com o banimento do MTBE em diversos estados americanos, provocou verdadeira corrida na busca de fontes e processos para tal provimento, estima-se que o EUA consumirá 120 bilhões de litros de etanol em 2025. Empresas brasileiras do ramo sucroalcooleiro são assediadas por multinacionais que desejam entrar no mercado que se mostra muito promissor.

O consumo de etanol no Brasil tende a crescer ainda mais, uma vez que a maioria dos veículos produzidos já são Flex, a necessidade de assegurar o abastecimento interno também é questão de opção estratégica e política. $\mathrm{O}$ aumento do preço internacional do petróleo é ainda uma incógnita, pois o preço também é político em muitas situações. Uma redução proposital poderá fazer que o lado financeiro fale mais alto e projetos fracassem. A Comunidade Européia colocou como prioridade a redução do consumo de combustíveis baseados no petróleo enfatizando o uso do biocombustíveis como meta, mas também indica que tal fato só se dará quando o preço do petróleo atingir noventa euros o barril.

O Brasil domina o processo de produção de etanol e atualmente está entre os maiores produtores. Porém, a história nos mostra que o mesmo aconteceu com a borracha, com o café e até mesmo com a cana-de-açúcar, que após o domínio produtivo foi ultrapassado por questões tecnológicas e logísticas ficando com o seu parque defasado em relação às demais nações. O contínuo desenvolvimento de novos métodos 
e ampliação do uso de matérias-primas, como o sorgo, trará ao Brasil uma maior segurança e distribuição na riqueza gerada. Caso contrário acontecerá a exploração por partes de grandes empresas internacionais do potencial brasileiro até o seu sucateamento e esgotamento. Não se pode permitir que os dividendos da produção se distanciem das fronteiras brasileiras.

A popularização da produção em pequenas comunidades ou cooperativas a partir das mais variadas fontes orgânicas é uma chance de termos uma melhor distribuição de renda, geração de trabalho na área agrícola, permite a criação de novos pólos agroindústrias e fixa o homem ao campo desafogando os grandes centros. Plantas menores com maiores eficiência devem ser produzidas em larga escala provocando uma diminuição de custos para aquisição.

O projeto energético para o futuro deve prever e estimular a descentralização na geração e consumo energético, possibilitando uma administração mais justa e humana e interação com outras fontes energéticas como solar e eólica a fim de permitir uma maior oferta de condições de vida a população brasileira. 


\section{REFERÊNCIAS}

ANDERSON, I. C.; ETHANOL FRON SWEET SORGHUM, Iowa State University. Disponível em $<$ http://www.energy.iastate.edu/renewable/biomass/cs-anerobic2.html $>$. Acessado em 5 de outubro de 2006.

ANFAVEA. Associação Nacional dos Fabricantes de Veículos Automotores.

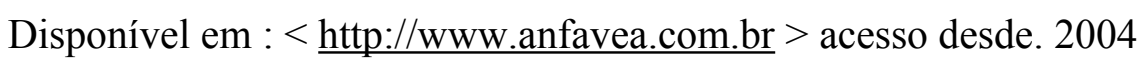

ANFAVEA - Industria Automobilística Brasileira 50 Anos, 2006. Disponível em http://www.anfavea.com.br/50anos/indice.pdf acessado em 28 de fevereiro de 2007

Balanço Energético Nacional 2005: Ano base 2004. Relatório final / Ministério de Minas e Energia. Empresa de Pesquisa Energética. Rio de Janeiro, EPE, 2005.

Balanço Energético Nacional 2006: Ano base 2005. Relatório preliminar / Ministério de Minas e Energia. Empresa de Pesquisa Energética. Rio de Janeiro, EPE, 2006.

BERG, C.; World Fuel Ethanol Analysis and Outlook - F.O-Licht, Germany, 2004. Disponível em $<$ www.distill.com/World-Fuel-Ethanol-A\&O-2004.html $>$. Acessado em 06 junho de 2004.

BERG, C - Seminário- World Fuel Ethanol- Analysis and Outlook, disponível em< www.meti.go.jp/report/downloadfiles/g30819b40j.pdf $>$ Acessado em 20 de agosto de 2004.

BERTELli, L.G. A verdadeira história do PROÁLCOOL. São Paulo, Jornal Estado de São Paulo, 2005.

Bhadari, H. C.; Mitra, A. K. e Malik, V. K. Treatment of distillery effluent, Proceedings of the $43^{\text {rd }}$ Annual Convention of The Sugar Technologist of India. Kanpur, 1979, G65-72.

BP - British Petroleum - Disponínel em: < www.bp.com> Acessado desde 2002.

BRANDÃO, A. Cana-de-açúcar: álcool e açúcar na história e no desenvolvimento social do Brasil, Brasília, Distrito Federal: Horizonte Editora: Em convênio com o Instituto Nacional do Livro, Fundação Nacional Pró-Memória, 1985. 
BURNQUIST, H. L Brasil alavanca mercado mundial de álcool. São Paulo, Jornal de Piracicaba, 2003.

CAMPEBELL, C.J.; ASPO- Newsletters nº73 January 2007.

CARVALHO, L.C. C Agroanalysis - A revista de agronegócios da FGV - vol. 21 $\mathrm{n}^{\circ} 9,2001$.

CCE. Comunicado da Comunidade Européia; Estratégia da União Europeia no domínio dos biocombustíveis, Bruxelas, 2006.

CENEH. Etanol é considerado combustível ideal para células a combustível. Campinas, Boletim Eletrônico Ano 1, No. 004 Outubro/2002

CETESB. Companhia de Tecnologia de Saneamento Ambiental Ciência e Tecnologia a Serviço do Meio Ambiente. Secretaria de Estado do Meio Ambiente. Disponível em : < http://www.cetesb.sp.gov.br $>$ Acesso em 2006.

CONAB. Companhia Nacional de Abastecimento. Disponível em : $<$ http://www.conab.gov.br> Acessado em maio de 2006.

COPERSUCAR. Cooperativa de Produtores de Cana-de-açúcar, Açúcar e Álcool

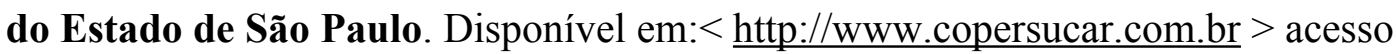
desde março 2003.

COPERSUCAR. Geração de Energia por biomassa: Bagaço de cana-de-açúcar e resíduos. Projeto. BRA/96/G31 (PNUD/MCT). Centro de Tecnologia COPRERSUCAR, relatório mar., 1998.

CRA - Corn Refiners Association, Disponível em www.corn.org/web/process.htm. Acessado em 20 de novembro de 2006

Ecoport.org, Banco de dados e imagens. Disponível em $<$ http://ecoport.org/ep?Plant=1982\&entityType=PL****\&entityDisplayCategory=Photo graphs> . Acessado em 10 dezembro de 2006.

Energy Information Administration. The Annual Energy Outlook 2004. (EIA), USA Washington, DC. 2004. 
EIA Bioenergy - IEA Bioenergy News 18(2).pdf<

http://www.ieabioenergy.com/LibItem.aspx?id=5398> Acessado em 02 de novembro de 2006

FAO, Integrated energy systems in China - The cold Northeastern region experience. FOOD AND AGRICULTURE ORGANIZATION OF THE UNITED NATIONSRome, 1994

FAO.; Sweet Sorghum in China. Spotlight/2002FOOD AND AGRICULTURE ORGANIZATION OF THE UNITED NATIONS, Rome, 2002

FAPESP. Revista Pesquisa FAPESP. Achados preciosos. Edição Impressa 52. Abril 2000

Folha de São Paulo, Caderno Panorâmica - Energia, Bush elogia uso do etanol e carros "flex" no Brasil. Janeiro de 2006

Folha de São Paulo, Protocolo de Kyoto entra em vigor sem ratificação dos EUA. Fevereiro de2005.

F.O. Licht - Licht Interactive Data, Disponível em $<$ www.agra-net.com $>$ Acessado em junho de 2004.

F.O. Licht - World Ethanol \& Biofuels Report 8, 2006

FUEL CELLS. COM - Site informativo de fabricantes, pesquisadores e noticias sobre o desenvolvimento mundial de células a combustível.

GARNERO, M. Energia: o futuro é hoje, São Paulo, ANFAVEA, 1980.

GROODE, T.; Review of Corn Based Ethanol Energy Use and Greenhouse Gas Emissions, Massachusetts, MIT, 2006

IBGE. Site do Instituto Brasileiro de Geografia e Estatística. Disponível em

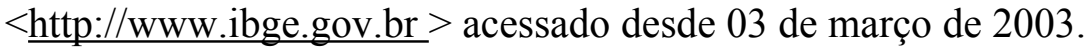

ICRISAT- International Crops Research Institute for the Semi-Arid Tropics, Disponível em $<$ http://www.icrisat.org $>$ acessado em 01dezembro de 2006 
INSTITUTO NACIONAL DE TECNOLOGIA, Informativo do INT, vol.XII, n22, pg3-23, 1979.

LAMNET- Biomass, Rural Energy and the Environment, Global multi-stakeholder networks linking knowledge and policy in support of sustainable development, JOHANNESBURG, 2002

MACEDO I. C., Leal M. R. L. V., Silva J. E.: Balanço das emissões de gases do efeito estufa na produção e no uso do etanol no Brasil; Secretaria do Meio Ambiente do Estado de São Paulo; 2004.

MACEDO, I. C. Uso da biomassa para produção de energia na indústria brasileira Organização: Frank Rosillo-Calle, Sergio V. Bajay e Harry Rothman. Editora Unicamp, 2006.

MACHADO, FBP. Brasil, a doce terra. Jornal Cana. Disponível em:

$<$ http://www.jornalcana.com.br/conteudo/historiadoSetor.htm>. Acesso em: $21 \mathrm{de}$ janeiro de 2003.

MAPA. Site oficial do Ministério da Agricultura do Brasil . Disponível em: $<$ http://www.agricultura.gov.br $>$. Acesso desde 25 de abr. 2003.

MDCI . Site oficial do Ministério de Desenvolvimento, Indústria e Comércio Exterior. Disponível em: < http://www.desenvolvimento.gov.br $>$ Acesso desde 2003.

MENEZES, T.J.B. Etanol o combustível do Brasil. Editora Agronômica Ceres, São Paulo, 1980.

MILLER, F.R. Use of sorghum to produced fermented energy sources. Texas. Agricultural Experiments Station. I Reunião do Sorgo Sacarino. Sete Lagoas, MG, fevereiro de 1977.

MINISTÉRIO DA CIENCIA E TECNOLOGIA. Site oficial do Ministério da Ciência e Tecnologia do BrasiL. Disponível em:<http://www.mct.gov.br $>$ Acesso desde 17 de jul. 2003.

MME. Site oficial do Ministério da Minas e Energia do governo do Brasil. Disponível em: <http://www.mme.gov.br>. Acesso desde abr. 2003. 
NARI - Nimbkar Agricultural Research Institute, Sweet sorghum R\&D at the Nimbkar Agricultural Research Institute. 2001

NASA GISS. NASA Goddard Institute for Space Studies. Disponível em <www.giss.nasa.gov> . Acessado em 13 de janeiro e 2007.

NASTARI, P.M.; MACEDO, I.C.; SWARC, A.; Observation on the Draft Document entitled “ Potencial for Biofuel for Transtort in Developing Countries”, Julho 2005. Disponível em < www.unica.com.br/i pages/files/ibm.pdf $>$ acessado Agosto de $\underline{2005}$.

NASTARI, P.M. Tendência Mundiais para o Uso de Etanol. Etanol balanço e perspectivas. Campinas, nov. 2005

NEIVA, J. Conheça o Petróleo, Edit. Ao livro técnico , Rio de Janeiro, 1983

NYBOT , Announces Revised Ethanol And Sugar Opening And Closing Times, Nova York, 2004.

OLIVETTI, M.P. de A.; CAMARGO, A.M.M. P. de. Aspectos econômicos e desenvolvimento da cultura do sorgo. Informações Econômicas, São Paulo, v.7, n. 1, 1997.

ORTEGA, Enrique. Mini-Usina de Álcool Integrada (MUAI), Vetor de Desenvolvimento Regional Sustentável. In: WORKSHOP DE PESQUISA E DESENVOLVIMENTO UNICAMP-CPFL, 1.,2003, Campinas - SP. Workshop de Pesquisa e Desenvolvimento Unicamp-CPFL. Campinas - SP: UNICAMP/PróReitoria de Pesquisa: CPFL, 2003, p. 80.

PIMENTEL, D.; PATZEK, P. Ethanol production using corn, switchgrass, and wood; Biodiesel production using soybean and sunflower. Natural Resources Research. v. 14, n. 1, p. 65-76, 2005.

PATZEK, P.; The Real Fuel Cycles. University of California, Berkely, California, 2006.

POOLE, A. Estudo sobre o etanol e o metanol como alternativas para a substituicao do petroleo no brasil. São Paulo, Inst de Fisica/USP, 1979. 
RFA - Renewable Fuels Association USA - Site odficial dos produtores de Etanol do Estados Unidos. < $\quad$ http://www.ethanolrfa.org $>$ acessado desde 2003.

RFA - ETHANOL INDUSTRY OUTLOOK 2006, Disponível em $<\underline{\text { http://www.etha- }}$ nolrfa.org $>$ Acessado em 8 de janeiro de 2007.

ROSSEL, C.E.V.; Entrevista ao Jornal Inovação, UNICAMP, Campinas, 2006. Disponível em < www.inovacao.unicamp.br/report/entre-rossell.shtml $>$, acessado em $10 \mathrm{de}$ novembro de 2006.

SANT`ANNA, E.A.D.; Desafios da Logística para distribuição de biocombustíveis, Seminário Internacional de Biocombustíveis - OLADE - Brasília Abril 2006

SCHWARTZMAN, S.; MAGAlHÃES, M.H.; A História do Instituto Nacional de Tecnologia; Rio de Janeiro, maio de 1997. Disponível em $<$ http://www.schwartzman.org.br/simon/int/int4.htm>, acessado em agosto de 2005.

SZWARC, A.; Key Issues for the World Biofuels Market. In Hart's World Refining \& Fuels Conference: Americas, 2006, Rio de Janeiro.

TEIXEIRA, Cyro Gonçalves; JARDINE, José Gilberto; BEISMAN, Darcy Antônio. Utilização do sorgo sacarino como matéria-prima complementar à cana-de-açúcar para obtenção de etanol em micro destilaria. Ciênc. Tecnol. Aliment., Campinas, v. 17, n. 3, 1997. Disponível em : <http://www.scielo.br/scielo.php Acessado em 31 de Jun de 2004.

TRANSPETRO - Jornal Transpetro n 58, outubro de 2006.

UNICA - União da Agroindústria Canavieira de São Paulo - Site oficial. $<$ http://www.unica.com.br> - acessado desde 2001.

VIZIOLI, J. O álcool industrial e a defesa da indústria açucareira. Secretaria da Agricultura, Industria e Comércio do Estado de São Paulo, 65p, 1930.

ZINK, F ; GONÇALVES , R. ; PASSOS, S. M. Cultura de cana-de açúcar. Boletim Técnico n. ${ }^{0} 121$ da Secretaria da Agricultura do Estado de São Paulo,15p , 1978. 
ANEXO A

LEI ESTADUAL Nº 11.241, DE 19 DE SETEMBRO DE 2002

Dispõe sobre a eliminação gradativa da queima da palha da cana-de-açúcar e dá providências correlatas.

\section{O GOVERNADOR DO ESTADO DE SÃO PAULO:}

Faço saber que a Assembléia Legislativa decreta e eu promulgo a seguinte lei:

Artigo $1^{\circ}$ - Esta lei dispõe sobre a eliminação do uso do fogo como método despalhador e facilitador do corte da cana-de-açúcar.

Artigo $2^{\circ}$ - Os plantadores de cana-de-açúcar que utilizem como método de pré-colheita a queima da palha são obrigados a tomar as providências necessárias para reduzir a prática, observadas as seguintes tabelas:

\begin{tabular}{|c|c|c|}
\hline ANO & $\begin{array}{l}\text { ÁREA MECANIZÁVEL ONDE NÃO SE } \\
\text { PODE } \\
\text { EFETUAR A QUEIMA }\end{array}$ & $\begin{array}{l}\text { PERCENTAGEM DE } \\
\text { ELIMINAÇÃO DA } \\
\text { QUEIMA }\end{array}$ \\
\hline $\begin{array}{l}1^{\circ} \text { ano } \\
(2002)\end{array}$ & $20 \%$ da área cortada & $20 \%$ da queima eliminada \\
\hline $\begin{array}{l}5^{\circ} \text { ano } \\
(2006)\end{array}$ & $30 \%$ da área cortada & $30 \%$ da queima eliminada \\
\hline $\begin{array}{l}10^{\circ} \text { ano } \\
(2011)\end{array}$ & $50 \%$ da área cortada & $50 \%$ da queima eliminada \\
\hline $\begin{array}{l}15^{\circ} \text { ano } \\
(2016)\end{array}$ & $80 \%$ da área cortada & $80 \%$ da queima eliminada \\
\hline $\begin{array}{l}20^{\circ} \text { ano } \\
(2021)\end{array}$ & $100 \%$ da área cortada & Eliminação total da queima \\
\hline ANO & $\begin{array}{l}\text { ÁREA NÃO MECANIZÁVEL, COM } \\
\text { DECLIVIDADE SUPERIOR A } 12 \% \text { E/OU } \\
\text { MENOR DE 150ha (cento e cinqüenta } \\
\text { hectares), ONDE NÃO SE PODE EFETU- } \\
\text { AR A QUEIMA }\end{array}$ & $\begin{array}{l}\text { PERCENTAGEM DE } \\
\text { ELIMINAÇÃO DA } \\
\text { QUEIMA }\end{array}$ \\
\hline $\begin{array}{l}10^{\circ} \text { ano } \\
(2011)\end{array}$ & $10 \%$ da área cortada & $10 \%$ da queima eliminada \\
\hline $\begin{array}{l}15^{\circ} \text { ano } \\
(2016)\end{array}$ & $20 \%$ da área cortada & $20 \%$ da queima eliminada \\
\hline $\begin{array}{l}20^{\circ} \text { ano } \\
(2021)\end{array}$ & $30 \%$ da área cortada & $30 \%$ da queima eliminada \\
\hline $\begin{array}{l}25^{\circ} \text { ano } \\
(2026)\end{array}$ & $50 \%$ da área cortada & $50 \%$ da queima eliminada \\
\hline $\begin{array}{l}30^{\mathbf{o}} \text { ano } \\
(2031)\end{array}$ & $100 \%$ da área cortada & $100 \%$ da queima eliminada \\
\hline
\end{tabular}

1 - áreas mecanizáveis: as plantações em terrenos acima de 150 ha (cento e cinqüenta hectares), com declividade igual ou inferior a 12\% (doze por cento), em solos com estruturas que permitam a adoção de técnicas usuais de mecanização da atividade de corte de cana;

2 - áreas não mecanizáveis: as plantações em terrenos com declividade superior a $12 \%$ (doze por cento), em demais áreas com estrutura de solo que inviabilizem a adoção de técnicas usuais de mecanização da atividade de corte de cana. 
$\S 2^{\circ}$ - Aplica-se o disposto neste artigo às áreas de cada imóvel rural, independentemente de estar vinculado a unidade agroindustrial.

$\S 3^{\circ}$ - As áreas cultivadas em que se deixar de empregar o fogo poderão ser substituídas por outras áreas cultivadas pelo mesmo fornecedor ou pela mesma unidade agroindustrial, desde que respeitado o percentual estabelecido no "caput" deste artigo.

Artigo $3^{\circ}$ - Os canaviais plantados a partir da data da publicação desta lei, ainda que decorrentes da expansão dos então existentes, ficarão sujeitos ao disposto no artigo $2^{\circ}$.Parágrafo único - Não se considera expansão a reforma de canaviais existentes anteriormente à publicação desta lei.

Artigo $4^{\circ}$ - Não se fará a queima da palha da cana-de-açúcar a menos de:

I - 1 (um) quilômetro do perímetro da área urbana definida por lei municipal e das reservas e áreas tradicionalmente ocupadas por indígenas;

II - 100 (cem) metros do limite das áreas de domínio de subestações de energia elétrica; III - 50 (cinqüenta) metros contados ao redor do limite de estação ecológica, de reserva biológica, de parques e demais unidades de conservação estabelecidos em atos do poder federal, estadual ou municipal e de refúgio da vida silvestre, conforme as definições da Lei federal $\mathrm{n}^{\circ} 9.985$, de 18 de julho de 2000 ;

IV - 25 (vinte e cinco) metros ao redor do limite das áreas de domínio das estações de telecomunicações;

$\mathrm{V}$ - 15 (quinze) metros ao longo dos limites das faixas de segurança das linhas de transmissão e de distribuição de energia elétrica;

VI - 15 (quinze) metros ao longo do limite das áreas de domínio de ferrovias e rodovias federais e estaduais.

Parágrafo único - A partir dos limites previstos nos incisos anteriores, deverão ser preparados, ao redor da área a ser submetida ao fogo, aceiros de, no mínimo, 3 (três) metros, mantidos limpos e não cultivados, devendo a largura ser ampliada, quando as condições ambientais, incluídas as climáticas, e as condições topográficas exigirem tal ampliação.

Artigo $5^{\circ}$ - O responsável pela queima deverá:

I - realizar a queima preferencialmente no período noturno, compreendido entre o pôr e o nascer do sol, evitando-se os períodos de temperatura mais elevada e respeitando-se as condições dos ventos predominantes no momento da operação de forma a facilitar a dispersão da fumaça e minimizar eventuais incômodos à população;

II - dar ciência formal e inequívoca aos confrontantes, por si ou por seus prepostos, da intenção de realizar a queima controlada, com o esclarecimento de que, oportunamente, a operação será confirmada com indicação de data, hora de início e local;

III - dar ciência formal, com antecedência mínima de 96 (noventa e seis)horas, da data, horário e local da queima aos lindeiros e às unidades locais da autoridade do Departamento Estadual de Proteção de Recursos Naturais - DEPRN;

IV - quando for o caso, sinalizar adequadamente as estradas municipais e vicinais, conforme determinação do órgão responsável pela estrada;

$\mathrm{V}$ - manter equipes de vigilância adequadamente treinadas e equipadas para o controle da propagação do fogo, com todos os petrechos de segurança pessoal necessários;

VI - providenciar o acompanhamento de toda a operação de queima, até sua extinção, com vistas à adoção de medidas adequadas de contenção do fogo na área definida para o emprego do fogo.

Parágrafo único - É vedado o emprego do fogo, numa única operação de queima, em área contígua superior a 500 ha (quinhentos hectares), independentemente de o requerimento ter sido feito de forma individual, coletiva ou por agroindústria.

Artigo $6^{\circ}$ - O requerimento de autorização, para cada imóvel, independentemente de estar vinculado a agroindústria, deve ser instruído nos termos do regulamento. 
$\S 1^{\circ}$ - Sendo contíguos os imóveis, o requerimento de autorização pode ser instruído com uma única planta, observadas as exigências fixadas, sendo que cada imóvel deverá ser referido à respectiva matrícula ou ao documento imobiliário a que corresponder. $\S 2^{\circ}$ - Considera-se comunicação de queima controlada de palha de cana-de-açúcar o documento subscrito pelo interessado no emprego do fogo para despalhamento da canade-açúcar, mediante o qual dá ciência à autoridade ambiental, ou ao órgão regional que esta determinar competente, de que cumpriu os requisitos e as exigências do artigo $4^{\circ}$ da Lei $\mathrm{n}^{\mathrm{o}} 10.547$, de 2 de maio de 2000, e desta lei.

$\S 3^{\circ}$ - O requerimento para a queima pode ser apresentado individualmente pelo titular do imóvel, por grupo de titulares ou por agroindústria que mantenha com o mesmo titular, ou diversos titulares, contrato de arrendamento, parceria ou outro instrumento hábil a garantir o fornecimento de cana-de-açúcar para suas atividades.

$\S 4^{\circ}$ - No caso de grupo de titulares, o documento poderá ser subscrito pela associação de fornecedores de cana-de-açúcar da região onde se insere a área objeto da queima, ficando os associados responsáveis pelo cumprimento das exigências legais e a entidade apenas pela apresentação dos documentos necessários à instrução do requerimento.

$\S 5^{\circ}$ - Excepcionado o disposto no parágrafo anterior, caso o requerimento seja feito por grupo de titulares ou por agroindústria, cabe ao interessado subscrever a comunicação de queima controlada.

$\S 6^{\circ}$ - O requerimento será instruído com procuração específica, quando efetuado por terceiro, pessoa física ou jurídica.

Artigo $7^{\circ}$ - A autoridade ambiental determinará a suspensão da queima quando:

I - constatados e comprovados risco de vida humana, danos ambientais ou condições meteorológicas desfavoráveis;

II - a qualidade do ar atingir comprovadamente índices prejudiciais à saúde humana, constatados segundo o fixado no ordenamento legal vigente;

III - os níveis de fumaça originados da queima, comprovadamente, comprometam ou coloquem em risco as operações aeronáuticas, rodoviárias e de outros meios de transporte.

Artigo $8^{\circ}$ - Os requerimentos para a queima devem ser protocolados até o dia 2 de abril de cada ano, na unidade do Departamento Estadual de Proteção de Recursos Naturais DEPRN que atender a respectiva região.

$\S 1^{\circ}$ - A autorização será expedida:

1 - no prazo de 15 (quinze) dias úteis, a contar da data em que for protocolado o requerimento, salvo se houver exigência a ser cumprida, que deverá ser comunicada ao interessado por escrito, no prazo de 10 (dez) dias úteis, a contar da data do protocolo;

2 - no prazo de 15 (quinze) dias úteis, a contar da data do cumprimento da exigência a que se refere o item anterior;

3 - expirados os prazos constantes neste parágrafo, considera-se automaticamente concedida a respectiva autorização, independentemente de sua comunicação ou de qualquer outra manifestação da autoridade ao requerente.

$\S 2^{\circ}$ - O requerimento de que trata o "caput" deste artigo poderá ser enviado por meios de comunicação eletrônicos.

Artigo $9^{\circ}$ - A Secretaria de Agricultura e Abastecimento manterá cadastro das colheitadeiras disponíveis, por tipo, capacidade, idade e outros elementos essenciais, bem como de todas as novas colheitadeiras ou equipamentos ligados à operação.

Artigo 10 - O Poder Executivo, com a participação e colaboração dos Municípios onde se localizam as agroindústrias canavieiras e dos sindicatos rurais, criará programas visando:

I - à requalificação profissional dos trabalhadores, desenvolvida de forma conjunta com os respectivos sindicatos das categorias envolvidas, em estreita parceria de metas e custos; 
II - à apresentação de alternativas aos impactos sócio-político-econômicos e culturais decorrentes da eliminação da queima da palha da cana-de-açúcar;

III - ao desenvolvimento de novos equipamentos que não impliquem dispensa de elevado número de trabalhadores para a colheita da cana-de-açúcar;

IV -ao aproveitamento energético da queima da palha da cana-de-açúcar, de modo a possibilitar a venda do excedente ao sistema de distribuição de energia elétrica.

Artigo 11 - A Secretaria de Agricultura e Abastecimento, através dos órgãos e dos Conselhos Municipais e Câmaras Setoriais da Cana-de-Açúcar, com a participação das demais Secretarias envolvidas, acompanhará a modernização das atividades e a avaliação dos impactos da queima sobre a competitividade e ocorrências na cadeia produtiva. Artigo 12 - A Secretaria de Agricultura e Abastecimento, ouvida a Secretaria do Meio Ambiente, deverá autorizar, excepcionalmente, a queima da palha da cana-de-açúcar, com base em estudos técnico-científicos, como instrumento fitossanitário.

Artigo 13 - O não cumprimento do disposto nesta lei sujeita o infrator, pessoa física ou jurídica, às sanções e penalidades previstas na legislação.

Artigo 14 - $\mathrm{O}$ inciso IV e o $\S 1^{\circ}$ do artigo $1^{\circ}$ da Lei $n^{\circ} 10.547$, de 2 de maio de 2000, passam a ter a seguinte redação:

"IV -no limite da linha que simultaneamente corresponda:

a) à área definida pela circunferência de raio igual a 6.000 (seis mil) metros, tendo como ponto de referência o centro geométrico da pista de pouso e decolagem do aeroporto público; (NR)

b) à área cuja linha perimetral é definida a partir da linha que delimita a área patrimonial do aeroporto público, dela distanciando no mínimo 2.000 (dois mil) metros, externamente, em qualquer de seus pontos. (NR)

$\S 1^{\circ}$ - Quando se tratar de aeroporto público que opere somente nas condições visuais diurnas (VFR) e a queima se realizar no período noturno compreendido entre o pôr do sol e o nascer do sol, será observado apenas o limite de que trata a alínea "b" do inciso IV." (NR)

Artigo 15 - Esta lei será regulamentada no prazo de 60 (sessenta) dias.

Artigo 16 - Esta lei e suas disposições transitórias entram em vigor na data de sua publicação, ficando revogados o $\S 2^{\circ}$ do artigo $1^{\circ}$ e os artigos 16 e 17 da Lei $n^{\circ} 10.547$, de 2 de maio de 2000.

DISPOSIÇÕES TRANSITÓRIAS

Artigo $1^{\circ}$ - Os plantadores de cana-de-açúcar que não atingirem, até 31 de dezembro de 2006, o percentual estabelecido de 30\% (trinta por cento) de redução da queima na área mecanizável deverão apresentar à Secretaria do Meio Ambiente, no prazo de 90 (noventa) dias daquela data, plano de adequação para elaboração do Compromisso de Ajustamento de Conduta, de modo a atender a meta estabelecida no artigo $2^{\circ}$ desta lei, resguardados os impactos sócio-político-econômicos e ambientais.

Artigo $2^{\circ}$ - O cumprimento dos prazos para eliminação da queima em áreas não mecanizáveis, estabelecidos no artigo $2^{\circ}$ desta lei, fica condicionado à disponibilidade de máquinas e equipamentos convencionais que permitam o corte mecânico em condições econômicas nas áreas cultivadas com cana-de-açúcar, sem restrições de declividade superior a $12 \%$ (doze por cento) ou de estruturas de solos.

Artigo $3^{\circ}$ - A partir de 2006, quinquenalmente, deverão os prazos constantes do artigo

$2^{\circ}$ desta lei, referentes às áreas não mecanizáveis, serem reavaliados de acordo com o desenvolvimento tecnológico que viabilize novas máquinas, para a colheita mecânica, sem descurar do aspecto social econômico, preservando-se a competitividade da agroindústria da cana-de-açúcar paulista frente a dos demais Estados produtores.

Parágrafo único - As áreas que passarem a ser consideradas mecanizáveis em função da revisão do conceito de que trata o "caput" deste artigo deverão submeter-se ao cronograma previsto em tabela constante do artigo $2^{\circ}$ desta lei. 
Palácio dos Bandeirantes, 19 de setembro de 2002

GERALDO ALCKMIN

Lourival Carmo Monaco

Respondendo pelo expediente da Secretaria de Agricultura e Abastecimento

José Goldemberg

Secretário do Meio Ambiente

Rubens Lara

Secretário-Chefe da Casa Civil

Dalmo Nogueira Filho

Secretário do Governo e Gestão Estratégica

Publicada na Assessoria Técnico-Legislativa, aos 19 de setembro de 2002.

FONTE D.O.E

SEÇÃO I

PÁGINA 02

DATA PUB. 20/09/02

VOLUME 112

NÚMERO 180 


\section{ANEXO B \\ DECRETO ESTADUAL N 47.700, DE 11 DE MARÇO DE 2003 \\ Regulamenta a Lei $\mathrm{n}^{\circ} 11.241$, de 19 de setembro de 2002, que dispõe sobre a eliminação gradativa da queima da palha da cana-de-açúcar e dá providências correlatas.}

GERALDO ALCKMIN, Governador do Estado de São Paulo, no uso de suas atribuições legais e tendo em vista as disposições da Lei ${ }^{\circ}$ 11.241, de 19 de setembro de 2002,

Decreta:

Artigo $1^{\circ}$ - A eliminação do uso do fogo, como método despalhador e facilitador do corte da cana-de-açúcar, far-se-á de forma gradativa.

Artigo $2^{\circ}$ - Os plantadores de cana-de-açúcar que utilizem como método de précolheita a queima da palha, devem reduzir esta prática, observadas as seguintes tabelas:

\begin{tabular}{|c|c|c|}
\hline ANO & $\begin{array}{l}\text { ÁREA MECANIZÁVEL ONDE NÃO SE } \\
\text { PODE } \\
\text { EFETUAR A QUEIMA }\end{array}$ & $\begin{array}{l}\text { PERCENTAGEM DE } \\
\text { ELIMINAÇÃO DA } \\
\text { QUEIMA }\end{array}$ \\
\hline $\begin{array}{l}(2002) \\
1^{\circ} \text { ano }\end{array}$ & $20 \%$ da área cortada & $20 \%$ da queima eliminada \\
\hline $\begin{array}{l}5^{\circ} \text { ano } \\
(2006)\end{array}$ & $30 \%$ da área cortada & $30 \%$ da queima eliminada \\
\hline $\begin{array}{l}10^{\circ} \text { ano } \\
(2011)\end{array}$ & $50 \%$ da área cortada & $50 \%$ da queima eliminada \\
\hline $\begin{array}{l}15^{\circ} \text { ano } \\
(2016)\end{array}$ & $80 \%$ da área cortada & $80 \%$ da queima eliminada \\
\hline $\begin{array}{l}20^{\circ} \text { ano } \\
(2021)\end{array}$ & $100 \%$ da área cortada & Eliminação total da queima \\
\hline ANO & $\begin{array}{l}\text { ÁREA NÃO MECANIZÁVEL, COM } \\
\text { DECLIVIDADE SUPERIOR A } 12 \% \text { E/OU } \\
\text { MENOR DE 150ha (cento e cinqüenta } \\
\text { hectares), ONDE NÃ O SE PODE EFETU- } \\
\text { AR } \\
\text { A QUEIMA }\end{array}$ & $\begin{array}{l}\text { PERCENTAGEM DE } \\
\text { ELIMINAÇÃO DA } \\
\text { QUEIMA }\end{array}$ \\
\hline $\begin{array}{l}10^{\circ} \text { ano } \\
(2011)\end{array}$ & $10 \%$ da área cortada & $10 \%$ da queima eliminada \\
\hline $\begin{array}{l}15^{\circ} \text { ano } \\
(2016)\end{array}$ & $20 \%$ da área cortada & $20 \%$ da queima eliminada \\
\hline $\begin{array}{l}20^{\circ} \text { ano } \\
(2021)\end{array}$ & $30 \%$ da área cortada & $30 \%$ da queima eliminada \\
\hline $\begin{array}{l}25^{\circ} \text { ano } \\
(2026)\end{array}$ & $50 \%$ da área cortada & $50 \%$ da queima eliminada \\
\hline $\begin{array}{l}30^{\circ} \text { ano } \\
(2031)\end{array}$ & $100 \%$ da área cortada & $100 \%$ da queima eliminada \\
\hline
\end{tabular}

$\S 1^{\circ}$ - Para os efeitos deste Decreto, consideram-se: 
1. áreas mecanizáveis: as plantações em terrenos acima de 150ha (cento e cinqüenta hectares), com declividade igual ou inferior a 12\% (doze por cento), em solos com estruturas que permitam a adoção de técnicas usuais de mecanização da atividade de corte de cana;

2. áreas não mecanizáveis: as plantações em terrenos com declividade superior a $12 \%$ (doze por cento), em demais áreas com estrutura de solo que inviabilizem a adoção de técnicas usuais de mecanização da atividade de corte de cana.

$\S 2^{\circ}$ - A existência de estruturas de solo que impossibilitem a mecanização do corte de cana-de-açúcar deverão ser comprovadas e delimitadas pelo interessado, mediante laudo técnico elaborado pela Secretaria de Agricultura e Abastecimento ou por entidade pública ou privada por ela credenciada, a ser encaminhado à Secretaria do Meio Ambiente. $\S 3^{\circ}$ - Aplica-se o disposto neste artigo às áreas de cada imóvel rural, independentemente de estar vinculado a unidade agroindustrial.

$\S 4^{\circ}$ - As áreas cultivadas em que se deixar de empregar o fogo poderão ser substituídas por outras áreas cultivadas pelo mesmo fornecedor ou pela mesma unidade agroindustrial, desde que respeitado o percentual estabelecido no "caput" deste artigo.

Artigo $3^{\circ}$ - Os canaviais plantados a partir de 20 de setembro de 2002, data da publicação da Lei $\mathrm{n}^{\mathrm{o}} 11.241$, ainda que decorrentes da expansão dos então existentes, fícarão sujeitos ao disposto no artigo $2^{\circ}$ deste decreto.

Parágrafo único - Não se considera expansão a reforma de canaviais existentes anteriormente a 20 de setembro de 2002.

Artigo $4^{\circ}$ - Não se fará queima da palha da cana-de-açúcar a menos de:

I - 1 (um) quilômetro do perímetro da área urbana definida por lei municipal e das reservas e áreas tradicionalmente ocupadas por indígenas;

II - 100 (cem) metros do limite das áreas de domínio de subestações de energia elétrica; III - 50 (cinqüenta) metros contados ao redor do limite de estação ecológica, de reserva biológica, de parques e demais unidades de conservação estabelecidos em atos do poder federal, estadual ou municipal e de refúgio da vida silvestre, conforme as definições da Lei Federal $n^{\circ}$ 9.985, de 18 de julho de 2000;

IV - 25 (vinte e cinco) metros ao redor do limite das áreas de domínio das estações de telecomunicações;

$\mathrm{V}$ - 15 (quinze) metros ao longo dos limites das faixas de segurança das linhas de transmissão e de distribuição de energia elétrica;

VI - 15 (quinze) metros ao longo do limite das áreas de domínio de ferrovias e rodovias federais e estaduais;

VII - do limite da linha que simultaneamente corresponda:

a) à área definida pela circunferência de raio igual a 6.000 (seis mil) metros, tendo como ponto de referência o centro geométrico da pista de pouso e decolagem de aeroportos públicos;

b) à área cuja linha perimetral é definida a partir da linha que delimita a área patrimonial de aeroporto público, dela distanciando no mínimo 2.000 (dois mil) metros, externamente, em qualquer de seus pontos.

$\S 1^{\circ}$ - Quando se tratar de aeroporto público que opere somente nas condições visuais diurnas (VFR) e a queima se realizar no período noturno compreendido entre o pôr do sol e o nascer do sol, será observado apenas o limite de que trata a alínea "b", do inciso VII deste artigo.

$\S 2^{\circ}$ - A partir dos limites previstos nos incisos I a VII deste artigo, deverão ser preparados, ao redor da área a ser submetida ao fogo, aceiros com largura mínima de 3 (três) metros. 
$\S 3^{\circ}$ - Os aceiros referidos no parágrafo anterior poderão ser preparados antes do início da área de restrição de emprego de fogo, desde que representem melhor técnica agrícola, aumentando a segurança.

Artigo $5^{\circ}$ - A largura dos aceiros, referidos no $\S 2^{\circ}$ do artigo anterior, será ampliada quando a queima se realizar em locais confrontantes com:

I - áreas de preservação permanente dos cursos d'água, das lagoas, dos lagos, dos reservatórios d'água naturais ou artificiais e das nascentes, ainda que intermitentes e dos chamados "olhos d'água", a que se refere o artigo $2^{\circ}$ da Lei Federal $n^{\circ} 4.771$, de 15 de setembro de 1965 (Código Florestal), devendo o aceiro ser de 6 (seis) metros; II - áreas de reserva legal a que se refere o artigo 16 da Lei Federal no 4.771, de 15 de setembro de 1965 (Código Florestal), devendo o aceiro ser de 6 (seis) metros.

Artigo $6^{\circ}$ - A largura dos aceiros deverá ser ampliada, quando as condições ambientais, incluídas as climáticas, e as condições topográficas exigirem tal ampliação, mediante laudo da área técnica.

Artigo $7^{\circ}$ - As áreas cultivadas com cana-de-açúcar onde é proibida a queima nos termos do artigo $4^{\circ}$ deste decreto, não serão consideradas para o cálculo dos percentuais constantes das tabelas definidas no artigo $2^{\circ}$ deste decreto, devendo a percentagem de eliminação da queima ser calculada sobre o restante das áreas cultivadas com cana-deaçúcar a ser colhida na respectiva safra.

Artigo $8^{\circ}$ - O responsável pela queima deverá:

I - realizar a queima preferencialmente no período noturno, compreendido entre o pôr e o nascer do sol, evitando-se os períodos de temperatura mais elevada e respeitando-se as condições dos ventos predominantes no momento da operação, de forma a facilitar a dispersão da fumaça e minimizar eventuais incômodos à população; II - dar ciência formal e inequívoca aos confrontantes, por si ou por seus prepostos, da intenção de realizar a queima controlada, com o esclarecimento de que, oportunamente, a operação será confirmada com indicação da data, horário e local da queima; III - dar ciência formal, com antecedência mínima de 96 (noventa e seis) horas, com indicação da data, horário e local da queima aos lindeiros e às unidades locais da autoridade do Departamento Estadual de Proteção de Recursos Naturais - DEPRN, da Companhia de Tecnologia de Saneamento Ambiental - CETESB e da Polícia Ambiental; IV - quando for o caso, sinalizar adequadamente as estradas municipais e vicinais, conforme determinação do órgão responsável pela estrada;

$\mathrm{V}$ - manter equipes de vigilância adequadamente treinadas e equipadas para o controle da propagação do fogo, com todos os petrechos de segurança pessoal necessários;

VI - providenciar o acompanhamento de toda a operação de queima, até sua extinção, com vistas à adoção de medidas adequadas de contenção do fogo na área definida para o emprego do fogo.

$\S 1^{\circ}$ - E vedado o emprego do fogo, numa única operação de queima, em área contígua superior a 500 ha (quinhentos hectares), independentemente de o requerimento ter sido feito de forma individual, coletiva, ou por agroindústria.

$\S 2^{\circ}$ - O cumprimento do determinado no inciso III deste artigo, no que se refere à ciência às unidades locais do Departamento Estadual de Proteção de Recursos Naturais DEPRN e da Companhia de Tecnologia de Saneamento Ambiental - CETESB, poderá ser efetivado por meios de comunicação eletrônicos, diretamente à Secretaria do Meio Ambiente, que disponibilizará as informações às respectivas autoridades.

Artigo $9^{\circ}$ - O requerimento para queima poderá ser apresentado individualmente pelo titular do imóvel, por grupo de titulares ou por agroindústria.

$\S 1^{\circ}$ - No caso de grupo de titulares integrado por fornecedores de cana-de-açúcar, o requerimento poderá ser apresentado pela associação de fornecedores de cana-de-açúcar da região onde se insere a área objeto da queima, ficando os associados responsáveis 
pelo cumprimento das exigências legais e a associação apenas pela apresentação dos documentos necessários à instrução do requerimento.

$\S 2^{\circ}$ - No caso de grupo de titulares, integrado por agroindústrias interdependentes ou coligadas, poderá ser apresentado um único requerimento subscrito por uma das agroindústrias, representante das demais, ficando cada agroindústria responsável pelo cumprimento das exigências legais e a agroindústria representante apenas pela apresentação dos documentos necessários à instrução do requerimento.

Artigo 10 - O requerimento deverá ser apresentado até o dia 2 de abril de cada ano, admitida a utilização de meios de comunicação eletrônica, na forma a ser definida em resolução do Secretário do Meio Ambiente, instruído com as informações necessárias para:

I - identificação do produtor, do imóvel (Número do Certificado de Cadastro de Imóvel Rural - CCIR) e da modalidade de exploração;

II - localização geográfica do imóvel e mensuração das seguintes áreas:

a) total de cultura de cana-de-açúcar a ser colhida no ano dividida nas seguintes parcelas:

1. parcelas onde é proibida a queima nos termos do artigo $4^{\circ}$ deste decreto;

2. parcelas consideradas mecanizáveis pelo critério de declividade;

3. parcelas consideradas não-mecanizáveis pelo critério da declividade ou demais restrições técnicas previstas na Lei $\mathrm{n}^{\circ} 11.241$, de 19 de setembro de 2002;

b) totais das culturas mecanizáveis e não-mecanizáveis a serem colhidas sem emprego de fogo.

$\S 1^{\circ}$ - No caso de produtor com cultura de cana-de-açúcar, fundada em um único imóvel, com área de colheita de até 150 ha (cento e cinqüenta hectares), a localização geográfica do imóvel será satisfeita pela indicação de um ponto geográfico pertencente à área de cultura de cana-de-açúcar, em coordenadas geográficas UTM colhidas em carta oficial do Instituto Geográfico e Cartográfico do Estado de São Paulo - IGC.

$\S 2^{\circ}$ - A mensuração das áreas, tal como previsto no inciso II deste artigo, será satisfeita pela declaração no requerimento de seus valores totais.

$\S 3^{\circ}$ - No caso de produtores com culturas de cana-de-açúcar com áreas de colheita de até 150 ha (cento e cinqüenta hectares), fundadas em cada propriedade, quando apresentado por grupo de produtores ou por associação de classe, será permitido o fornecimento das informações simplificadas de caracterização dos imóveis, conforme descrito no $\S 1^{\circ}$ deste artigo, consolidadas em um único arquivo-texto, gerado em mídia magnética, na forma a ser definida em resolução do Secretário do Meio Ambiente.

$\S 4^{\circ}$ - No caso de produtores com culturas de cana-de-açúcar em áreas de colheita superior a 150 ha (cento e cinqüenta hectares), em imóveis isolados ou fruto da consolidação das áreas de cultura em imóveis contíguos ou, ainda, para todos os imóveis explorados por agroindústria com culturas de cana-de-açúcar, independentemente do porte da área de cultura, a localização geográfica do imóvel será satisfeita pela indicação do perímetro da área de cultura de cana-de-açúcar, a ser colhida no ano, sob forma de lista ordenada de seus vértices expressos em coordenadas UTM colhidas em carta oficial do Instituto Geográfico e Cartográfico do Estado de São Paulo - IGC.

$\S 5^{\circ}$ - A mensuração das áreas do inciso II deste artigo, será satisfeita pela declaração no requerimento de seus valores totais e indicação dos perímetros da área de cultura de cana-de-açúcar a ser colhida no ano, separando as áreas colhidas com e sem emprego de fogo para a despalha, sob forma de lista ordenada de seus vértices expressos em coordenadas UTM colhidas em carta oficial do Instituto Geográfico e Cartográfico do Estado de São Paulo - IGC.

$\S 6^{\circ}$ - No caso de requerimento de agroindústria, ou quando apresentado por grupo de produtores ou por associação de classe, será permitido o fornecimento das informações detalhadas de caracterização dos imóveis, conforme descritas nos $\S \S 4^{\circ}$ e $5^{\circ}$ deste artigo, 
consolidadas em um único arquivo-texto, gerado em mídia magnética na forma a ser definida em resolução do Secretário do Meio Ambiente.

Artigo 11 - No caso de a área objeto de requerimento não ter sido mapeada pelo Instituto Geográfico e Cartográfico do Estado de São Paulo - IGC, será permitida a utilização de carta do Instituto Brasileiro de Geografia e Estatística - IBGE, mas sempre na cartografia mais detalhadadisponível para a região.

Artigo 12 - Após a conclusão com êxito do procedimento de requerimento será emitido pelo sistema e encaminhado ao requerente o número de identificação e controle, que servirá como comprovante da autorização referida no $\S 1^{\circ}$, do artigo $8^{\circ}$ da Lei $n^{\circ} 11.241$, de 19 de setembro de 2002, sob condição de serem verdadeiras as informações constantes do requerimento de queima controlada relativas ao cumprimento dos requisitos e exigências estabelecidos nos artigos $2^{\circ}$ a $5^{\circ}$ dessa mesma Lei.

Artigo 13 - Considera-se cumprido o disposto no $\S 2^{\circ}$, do artigo $6^{\circ}$ da Lei $n^{\circ} 11.241$, de 19 de setembro de 2002, a comunicação pelo interessado, mediante meios eletrônicos, na forma a ser definida pela Secretaria do Meio Ambiente, com antecedência mínima de 96 (noventa e seis) horas, das parcelas dos imóveis onde será efetuada a queima na forma autorizada, explicitando a data, horário e local.

Parágrafo único - Caso ocorram fatos supervenientes à comunicação, devidamente fundamentados, que justifiquem a alteração de qualquer dos dados da comunicação, o interessado deverá fazer nova comunicação com os mesmos requisitos.

Artigo 14 - O Departamento Estadual de Proteção de Recursos Naturais - DEPRN, a Companhia de Tecnologia de Saneamento Ambiental - CETESB e a Polícia Ambiental determinarão a suspensão, parcial ou total, da queima quando:

I - constatados e comprovados risco de vida humana, danos ambientais ou condições meteorológicas desfavoráveis;

II - a qualidade do ar atingir comprovadamente índices prejudiciais à saúde humana, constatados segundo o fixado no ordenamento legal vigente;

III - os níveis de fumaça originados da queima, comprovadamente comprometam ou coloquem em risco as operações aeronáuticas, rodoviárias e de outros meios de transporte. Artigo 15 - O não cumprimento do disposto na Lei $\mathrm{n}^{\circ} 11.241$, de 19 de setembro de 2002, neste decreto e nas exigências e condições instituídas em razão da aplicação de suas normas, sujeita o infrator ao pagamento de multa de 30 (trinta) UFESP's por hectare de área queimada.

$\S 1^{\circ}$ - A penalidade estabelecida neste artigo será aplicada sem prejuízo das já estabelecidas na legislação federal, estadual e municipal que tenha por finalidade o controle da poluição e a proteção do meio ambiente.

$\S 2^{\circ}$ - Além das penalidades previstas neste artigo, o infrator será obrigado à recomposição da vegetação, quando for o caso, de acordo com critérios definidos pela Secretaria do Meio Ambiente.

$\S 3^{\circ}$ - As penalidades decorrentes do descumprimento das disposições deste decreto incidirão sobre o responsável pela queima, seja ele proprietário, arrendatário, parceiro, ou posseiro, ainda que praticadas por preposto ou subordinado e no interesse do proponente ou superior hierárquico.

Artigo 16 - Em caso de ocorrência de queima em áreas onde essa prática é vedada, nos termos do "caput" do artigo $2^{\circ}$ deste decreto, o interessado deverá transferir a respectiva restrição, na mesma proporção, para outra área cultivada a ser colhida na safra, comunicando o fato à Secretaria do Meio Ambiente, no prazo de 48 (quarenta e oito) horas do ocorrido, independentemente da aplicação das sanções cabíveis.

Artigo 17 - No ano de 2003 não será cobrado dos plantadores de cana-de-açúcar o preço de análise para autorização do uso do fogo em queima controlada fixado no Quadro II, do Anexo I do Decreto no 47.400, de 4 de dezembro de 2002, desde que apresentados por via eletrônica de acordo com resolução do Secretário do Meio Ambiente. 
Artigo 18 - Ficam dispensados do pagamento do Preço de Análise para autorização de queima controlada, os plantadores de cana-de-açúcar cujas propriedades individualizadas tenham áreas inferiores a 150 ha (cento e cinqüenta hectares) e não estejam vinculadas a agroindústria, exceto por contrato de fornecimento de cana-de-açúcar.

Artigo 19 - A Secretaria de Agricultura e Abastecimento, por seus órgãos próprios, elaborará questionário de acompanhamento para fins de cadastramento das colheitadeiras disponíveis, por tipo, capacidade, idade e outros elementos essenciais, bem como de novas colheitadeiras ou equipamentos ligados à operação, disponibilizando esses dados pela Coordenadoria de Assistência Técnica Integral - CATI e associações de classe ligadas ao setor sucroalcooleiro.

Artigo 20 - Os órgãos e entidades do Estado deverão estabelecer parcerias entre si e com os Municípios onde se localizam agroindústrias canavieiras e sindicatos rurais para o desenvolvimento de programas destinados a:

I - requalificar profissionalmente os trabalhadores envolvidos na produção sucroalcooleira;

II - apresentar alternativas aos impactos sócio-político-econômico-culturais decorrentes da eliminação da queima da palha da cana-de-açúcar;

III - acompanhar o desenvolvimento e a introdução de novos equipamentos que não impliquem dispensa de elevado número de trabalhadores envolvidos na colheita da canade-açúcar;

IV - estimular o aproveitamento energético da queima da palha da cana-de- açúcar para possibilitar a venda do excedente ao sistema de distribuição de energia elétrica.

Artigo 21 - A Secretaria de Agricultura e Abastecimento, por intermédio dos seus órgãos, com a colaboração dos Conselhos Municipais e das Câmaras Setoriais da Canade-Açúcar, e a participação das demais Secretarias envolvidas, acompanhará a modernização das atividades e a avaliação dos impactos da queima sobre a competitividade e ocorrências na cadeia produtiva.

Artigo 22 - A Secretaria de Agricultura e Abastecimento, ouvida a Secretaria do Meio Ambiente, deverá autorizar, excepcionalmente, a queima da palha da cana-de-açúcar, com base em estudos técnico científicos, como instrumento fitossanitário.

Parágrafo único - A Agência de Defesa Agropecuária do Estado de São

Paulo - ADAESP estabelecerá, por ato próprio, os procedimentos necessários ao cumprimento do disposto neste artigo.

Artigo 23 - Este decreto e suas disposições transitórias entram em vigor na data de sua publicação, revogadas as disposições em contrário, especialmente o Decreto $n^{\circ} 45.869$, de 22 de junho de 2001.

DISPOSIÇÕES TRANSITÓRIAS

Artigo $1^{\circ}$ - Os plantadores de cana-de-açúcar que não atingirem, até 31 de dezembro de 2006, o percentual estabelecido de $30 \%$ (trinta por cento) de redução da queima na área mecanizável deverão apresentar à Secretaria do Meio Ambiente, no prazo de 90 (noventa) dias daquela data, plano de adequação para elaboração do Compromisso de Ajustamento de Conduta, de modo a atender a meta estabelecida no artigo $2^{\circ}$ deste decreto, resguardados os impactos sócio-político-econômicos e ambientais.

Parágrafo único - O plano de adequação deverá ser entregue na unidade do Departamento Estadual de Proteção de Recursos Naturais - DEPRN responsável pela região onde se situa a propriedade.

Artigo $2^{\circ}$ - $\mathrm{O}$ cumprimento dos prazos para eliminação da queima em áreas não mecanizáveis, estabelecidos no artigo $2^{\circ}$ deste decreto, fica condicionado à disponibilidade de máquinas e equipamentos convencionais que permitam o corte mecânico em condições econômicas nas áreas cultivadas com cana-de-açúcar, sem restrições de declividade superior a $12 \%$ (doze por cento) ou de estruturas de solos. 
Artigo $3^{\circ}$ - A partir de 2006, qüinqüenalmente, deverão os prazos constantes do artigo $2^{\circ}$ deste decreto, referentes às áreas não mecanizáveis, ser reavaliados de acordo com o desenvolvimento tecnológico que viabilize novas máquinas, para a colheita mecânica, sem descurar do aspecto social-econômico, preservando-se a competitividade da agroindústria da cana-de-açúcar paulista frente a dos demais Estados produtores.

Parágrafo único - As áreas que passarem a ser consideradas mecanizáveis em função da revisão do conceito de que trata o "caput" deste artigo deverão submeter-se ao cronograma previsto na tabela constante do artigo $2^{\circ}$ deste decreto.

FONTE D.O.E

SEÇÃO I

PÁGINA 03,04,05
DATA PUB. 12/03/2003

VOLUME 113

FASC. 48 
ANEXO C

\section{RESOLUÇÃO ANP № 36, DE 6.12.2005 - DOU 7.12.2005}

O DIRETOR-GERAL da AGÊNCIA NACIONAL DO PETRÓLEO, GÁS NATURAL E BIOCOMBUSTÍVEIS - ANP, no uso de suas atribuições legais, tendo em vista as disposições da Lei $n^{\circ} 9.478$ de 6 de agosto de 1997 alterada pela Lei $n^{\circ} 11.097$ de 13 de janeiro de 2005 e da Resolução de Diretoria $n^{\circ} 386$, de 01 de dezembro de 2005, torna público o seguinte ato:

Art. $1^{\circ}$. Ficam estabelecidas, através da presente Resolução, as especificações do Álcool Etílico Anidro Combustível (AEAC) e do Álcool Etílico Hidratado Combustível (AEHC) comercializados pelos diversos agentes econômicos em todo o território nacional, consoante as disposições contidas no Regulamento Técnico ANP $n^{\circ} 7 / 2005$, parte integrante desta Resolução.

Art. $2^{\circ}$. Para efeitos desta Resolução os álcoois etílicos combustíveis classificam-se em:

I - Álcool Etílico Anidro Combustível (AEAC) - produzido no País ou importado sob autorização, conforme especificação constante do Regulamento Técnico, destinado aos Distribuidores para mistura com gasolina $\mathrm{A}$ para formulação da gasolina $\mathrm{C} \mathrm{e}$,

II - Álcool Etílico Hidratado Combustível (AEHC) - produzido no País ou importado sob autorização, conforme especificação constante do Regulamento Técnico, para utilização como combustível em motores de combustão interna de ignição por centelha.

Art. $3^{\circ}$. Os Produtores e Importadores deverão manter sob sua guarda, pelo prazo mínimo de 2 (dois) meses a contar da data de comercialização do produto, uma amostratestemunha de cada batelada do produto comercializado, armazenada em embalagem identificada, lacrada e acompanhada de Certificado da Qualidade, documento que contém os resultados da análise de todas as características do produto, conforme requeridas no Regulamento Técnico, parte integrante desta Resolução.

$\S 1^{\circ} \mathrm{O}$ Certificado da Qualidade referente à batelada do produto comercializado deverá ter numeração seqüencial anual e ser firmado pelo químico responsável pelas análises laboratoriais efetuadas, com indicação legível de seu nome e número da inscrição no órgão de classe.

$\S 2^{\circ}$ Durante o prazo assinalado no caput deste artigo a amostra-testemunha e o respectivo Certificado de Qualidade deverão ficar à disposição da ANP para qualquer verificação julgada necessária.

$\S 3^{\circ}$ Fica dispensada a adição de corante à amostra testemunha.

Art. $4^{\circ}$. A documentação fiscal referente às operações de comercialização do $A E A C$ e do AEHC realizadas pelo Produtor ou Importador, deverá indicar o número do Certificado da Qualidade correspondente ao produto e ser acompanhada de cópia legível do mesmo, atestando que o produto comercializado atende à especificação. No caso de cópia emitida eletronicamente, deverão estar indicados, na cópia, o nome e o número da inscrição no órgão de classe do responsável técnico pelas análises laboratoriais efetuadas.

Art. $5^{\circ}$. Os produtores deverão enviar mensalmente à ANP/SQP, através do endereço eletrônico sqp@anp.gov.br, até o $15^{\circ}$ (décimo quinto) dia do mês subseqüente àquele a que se referirem os dados enviados, um resumo dos resultados constantes nos Certificados da Qualidade com os valores mínimo, máximo, médio e desvio das seguintes características: acidez, condutividade elétrica, massa específica, teor alcoólico, potencial hidrogeniônico, sulfato, ferro, cobre e sódio.

$\S 1^{\circ}$ As análises de sulfato, ferro, cobre e sódio serão realizadas quinzenalmente em uma amostra composta preparada a partir das amostras coletadas diariamente dos tanques em movimentação.

$\S 2^{\circ} \mathrm{Na}$ hipótese do AEAC ser transportado ou produzido em local que possua equipamentos ou linhas de cobre, ou ligas que contenham este metal, a análise de cobre deverá ser obrigatoriamente realizada para a emissão do Certificado da Qualidade. 
$\S 3^{\circ}$ Os resumos deverão conter a identificação da unidade produtora, o mês a que se referem os dados e o volume total de produto comercializado cujas amostras foram analisadas, em conformidade com o modelo abaixo.

\begin{tabular}{|l|l|l|l|l|l|l|}
\hline Característica & Método & Unidade & Mínimo & Máximo & Média & Desvio \\
\hline & & & & & & \\
\hline
\end{tabular}

onde:

Característica - item da respectiva especificação do produto;

Método - procedimento padronizado constante da especificação em vigor segundo o qual a característica foi analisada.

Unidade - unidade em que está reportado o valor da característica;

Mínimo, Máximo - valores mínimos e máximos encontrados nas determinações laboratoriais do mês de referência;

Média - média ponderada dos volumes objetos das análises realizadas;

Desvio - desvio padrão da amostragem.

$\S 4^{\circ}$ Adicionalmente, no caso do AEAC, os volumes comercializados deverão estar discriminados conforme a presença ou não de corante. Os volumes de AEAC comercializados sem corante, deverão ser devidamente justificados e informados a razão social e o CNPJ do adquirente, de acordo com o modelo a seguir:

\begin{tabular}{|l|l|l|l|}
\hline \multicolumn{2}{|c|}{ Volume comercializado (m3) } & \multicolumn{2}{c|}{ Adquirente } \\
\hline AEAC com corante & AEAC sem corante & CNPJ & Razão Social \\
\hline & & & \\
\hline
\end{tabular}

Art. $6^{\circ}$. O Distribuidor de combustíveis automotivos, autorizado pela ANP a realizar as adições de $A E A C$ à gasolina $A$, para produção da gasolina $C$, deverá manter sob sua guarda, pelo prazo mínimo de 1 (um) mês, uma amostra-testemunha armazenada em embalagem devidamente identificada, lacrada, coletada ao final do dia de cada tanque de AEAC em operação, acompanhada do Certificado da Qualidade emitido pelo Produtor ou Importador, sempre que houver recebimento deste produto.

Art. $7^{\circ}$. O Distribuidor de combustíveis automotivos deverá certificar a qualidade do $\mathrm{AEHC}$ a ser entregue ao Revendedor Varejista através da realização de análises laboratoriais em amostra representativa do produto, emitindo Boletim de Conformidade com numeração seqüencial anual assinado pelo responsável técnico, com indicação legível do nome e número da inscrição no órgão de classe, contendo as seguintes características do produto: aspecto, cor, massa específica, teor alcoólico, potencial hidrogeniônico e condutividade elétrica.

$\S 1^{\circ} \mathrm{O}$ Boletim de Conformidade original deverá ficar sob a guarda do Distribuidor, por um período de 2 (dois) meses, à disposição da ANP, para qualquer verificação julgada necessária.

$\S 2^{\circ}$ Os resultados da análise das características constantes do Boletim de Conformidade deverão estar enquadrados nos limites estabelecidos pelo Regulamento Técnico, devendo o produto atender às demais características especificadas.

$\S 3^{\circ} \mathrm{Em}$ caso de produto proveniente de dutos e/ou de transporte hidroviário, o Boletim de Conformidade deverá contemplar adicionalmente as seguintes características: resíduo por 
evaporação, teor de hidrocarbonetos e íon Cloreto, este último apenas no caso de produto proveniente de transporte hidroviário.

$\S 4^{\circ} \mathrm{A}$ documentação fiscal de comercialização do produto deverá indicar o número do Boletim de Conformidade e ser acompanhada de uma cópia do mesmo quando do fornecimento ao Revendedor Varejista. No caso de cópia emitida eletronicamente, deverão estar registrados, na cópia, o nome e o número da inscrição no órgão de classe do responsável técnico pelas análises laboratoriais efetuadas.

Art. $\mathbf{8}^{\circ}$. A ANP poderá, a qualquer tempo e às suas expensas, submeter os Produtores e Distribuidores a auditoria de qualidade, a ser executada por entidades certificadoras credenciadas pelo INMETRO, sobre os procedimentos e equipamentos de medição que tenham impacto sobre a qualidade e a confiabilidade dos procedimentos de que trata esta Resolução.

Art. $9^{\circ}$. O Distribuidor deverá enviar à ANP, através do endereço eletrônico distribuidor@anp.gov.br, até o $15^{\circ}$ (décimo quinto) dia do mês subseqüente àquele a que se referirem os dados enviados, um resumo dos resultados constantes nos Boletins de Conformidade emitidos, devendo conter:

I - identificação do Distribuidor;

II - mês de referência dos dados certificados;

III - volume total comercializado no mês;

IV - identificação do Produtor ou Importador de quem foi adquirido o AEHC e

$\mathrm{V}$ - tabela de resultados de acordo com o modelo a seguir:

\begin{tabular}{|l|l|l|l|l|l|l|}
\hline \multicolumn{1}{|c|}{ Característica } & Unidade & Método & Mínimo & Máximo & Média & Desvio \\
\hline $\begin{array}{l}\text { Massa específica a } \\
20^{\circ} \mathrm{C}\end{array}$ & $\mathrm{kg} / \mathrm{m} 3$ & & & & & \\
\hline Teor alcoólico & OINPM & & & & & \\
\hline $\begin{array}{l}\text { Potencial } \\
\text { hidrogeniônico }(\mathrm{pH})\end{array}$ & - & & & & & \\
\hline Condutividade elétrica & $\mu \mathrm{S} / \mathrm{m}$ & & & & & \\
\hline
\end{tabular}

onde:

Método - procedimento padronizado constante da especificação em vigor segundo o qual a característica foi analisada;

Mínimo, Máximo - valores mínimos e máximos encontrados nas determinações laboratoriais do mês de referência;

Média - média ponderada dos volumes objeto das análises realizadas;

Desvio - desvio padrão da amostragem.

Art. 10. Fica vedada a comercialização de Álcool Etílico Anidro Combustível (AEAC) e Álcool Etílico Hidratado Combustível (AEHC), definidos no art. $2^{\circ}$ desta Resolução, que não se enquadrem nas especificações do Regulamento Técnico.

Art. 11. O corante especificado na Tabela II do Regulamento Técnico ANP $n^{\circ} 7 / 2005$ deverá ser adicionado pelo Produtor, Importador e Transportador Dutoviário ao Álcool Etílico Anidro Combustível (AEAC) comercializado. 
$\S 1^{\circ}$ Fica dispensada a adição de corante ao Álcool Etílico Anidro Combustível (AEAC) destinado à exportação, cabendo ao exportador informar à ANP/SQP (expalcool@anp.gov.br) até a data do carregamento o volume, país de destino, a movimentação do produto em território nacional e o local por onde o produto deverá deixar o país. O exportador deverá também encaminhar à ANP/SQP cópia da respectiva Declaração de Despacho de Exportação - DDE registrada no SISCOMEX. A critério da ANP, outros requisitos considerados necessários para o controle desta modalidade de movimentação poderão ser exigidos.

$\S 2^{\circ} \mathrm{O}$ Produtor ou Importador poderá ser dispensado da adição do corante ao Álcool Etílico Anidro Combustível (AEAC) destinado ao mercado interno quando movimentado em polidutos.

$\S 3^{\circ} \mathrm{O}$ Transportador Dutoviário quando vier a destinar Álcool Etílico Anidro Combustível (AEAC) ao mercado interno fica obrigado a adicionar o corante.

$\S 4^{\circ} \mathrm{A}$ dispensa de que trata o $\S 2^{\circ}$ deste artigo será autorizada pela ANP, observadas as seguintes condições:

I - A autorização dos volumes será dada mediante solicitação do Produtor, Importador ou Transportador Dutoviário, que deverá informar os volumes por produtor, por ponto de entrega e destino do que for transportado;

II - A autorização da ANP dependerá da exigência e concordância prévia do Transportador Dutoviário;

III - O Produtor deverá informar à ANP, até o dia 15 do mês subseqüente, os volumes por caminhões-tanque, sua identificação, data de carregamento, pontos de entrega no Transportador Dutoviário; e

IV. A cada autorização, o Transportador Dutoviário deverá confirmar à ANP, no prazo de até 30 dias, o efetivo recebimento integral dos volumes, com as datas de recebimento, além das informações mencionadas no inciso III.

$\S 5^{\circ} \mathrm{O}$ Produtor, Importador ou Transportador Dutoviário de Álcool Etílico Anidro Combustível (AEAC) deverá manter uma amostra do corante utilizado pelo prazo de 2 (dois) meses à disposição da ANP para qualquer verificação julgada necessária.

$\S 6^{\circ} \mathrm{O}$ corante a ser adicionado ao Álcool Etílico Anidro Combustível (AEAC) deverá ser adquirido de fornecedor cadastrado na ANP/CPT o qual deverá comprovar a adequação do seu produto à especificação prevista no Regulamento Técnico ANP no 7/2005 - Tabela II e comercializá-lo acompanhado de Ficha de Segurança e Manuseio do Produto.

$\S 7^{\circ} \mathrm{A}$ solicitação de cadastro para fornecimento de corante deverá ser acompanhada de Certificado da Qualidade firmado pelo químico responsável pelas análises laboratoriais efetuadas, com indicação legível do nome e número da inscrição no órgão de classe, conforme Regulamento Técnico ANP $n^{\circ} 7 / 2005$ - Tabela II, Ficha de Segurança e Manuseio do Produto e de amostra do produto em concentração idêntica àquela comercializada. $O$ fornecedor de corante deverá ter o seu cadastro renovado anualmente.

Art. 12. Fica vedada a adição de qualquer corante ao Álcool Etílico Hidratado Combustível (AEHC), o qual deverá obrigatoriamente apresentar-se límpido e incolor.

Art. 13. Fica estabelecida a obrigatoriedade dos Postos Revendedores fixarem nas bombas de AEHC, para perfeita visualização do consumidor, adesivo com logotipo da ANP com os seguintes dizeres em letras vermelhas Arial tamanho 42 em fundo branco: "Consumidor, este álcool combustível somente poderá ser comercializado se estiver límpido e incolor." Denúncias: 0800-900-267.

Art. 14. O fornecedor do corante deverá informar mensalmente à ANP/SQP (corante@anp.gov.br) a quantidade total de corante comercializado com cada Produtor, Importador e Transportador Dutoviário de AEAC.

Art. 15..Fica concedido ao Produtor, ao Importador e ao Transportador Dutoviário de AEAC o prazo de 30 (trinta) dias para atender ao disposto no art. $11^{\circ}$ desta Resolução.

Art. 16. O não atendimento ao disposto nesta Resolução ou o desvio de álcool sem corante para outros destinos que não o transporte dutoviário sujeita os infratores às penalidades previstas na Lei $n^{\circ} 9.847$, de 26 de outubro de 1999 alterada pela Lei $n^{\circ} 11.097$, de 13 de janeiro de 2005. 
Art. 17. Esta Resolução entra em vigor na data de sua publicação no Diário Oficial da União.

Art. 18. Ficam revogadas a Portaria ANP $n^{\circ} \underline{2}$, de 16 de janeiro de 2002 e demais disposições em contrário.

HAROLDO BORGES RODRIGUES LIMA

\section{ANEXO \\ REGULAMENTO TÉCNICO ANP No 7/2005}

\section{Objetivo}

Este Regulamento Técnico aplica-se ao Álcool Etílico Anidro Combustível (AEAC) e ao Álcool Etílico Hidratado Combustível (AEHC), nacional ou importado, para uso como combustível e estabelece as suas especificações.

\section{Normas complementares}

A determinação das características do produto far-se-á mediante o emprego de Normas Brasileiras (NBR) da Associação Brasileira de Normas Técnicas (ABNT) ou das Normas da American Society for Testing and Materials (ASTM).

Os dados de exatidão, repetitividade e reprodutibilidade fornecidos nos métodos relacionados a seguir devem ser usados somente como guia para aceitação das determinações em duplicata do ensaio e não devem ser considerados como tolerância aplicada aos limites especificados neste Regulamento.

A análise do produto deverá ser realizada em amostra representativa do mesmo, coletada segundo as normas ASTM D4057 - Practice for Manual Sampling of Petroleum and Petroleum Products ou ASTM E300 - Practice for Sampling Industrial Chemicals.

3. As características constantes da Tabela das Especificações deverão ser determinadas de acordo com a publicação mais recente dos seguintes métodos de ensaio:

\begin{tabular}{|l|l|}
\hline MÉTODO & \multicolumn{1}{|c|}{ TíTULO } \\
\hline NBR 5992 & $\begin{array}{l}\text { Determinação da massa específica e do teor alcoólico do Álcool Etílico e suas } \\
\text { misturas com água }\end{array}$ \\
\hline NBR 8644 & Álcool Etílico Combustível - Determinação do resíduo por evaporação \\
\hline NBR 9866 & Álcool Etílico - Verificação da alcalinidade e determinação da acidez total \\
\hline $\begin{array}{l}\text { NBR } \\
10422\end{array}$ & Álcool Etílico - Determinação do teor de sódio por fotometria de chama \\
\hline $\begin{array}{l}\text { NBR } \\
10547\end{array}$ & Álcool Etílico - Determinação da condutividade elétrica \\
\hline $\begin{array}{l}\text { NBR } \\
10891\end{array}$ & Álcool Etílico Hidratado - Determinação do pH \\
\hline NBR & Álcool Etílico - Determinação do teor do cobre por espectrofotometria de \\
\hline
\end{tabular}




\begin{tabular}{|l|l|}
10893 & absorção atômica \\
\hline $\begin{array}{l}\text { NBR } \\
10894\end{array}$ & Álcool Etílico - Determinação dos íons cloreto e sulfato por cromatografia iônica \\
\hline $\begin{array}{l}\text { NBR } \\
10895\end{array}$ & Álcool Etílico - Determinação do teor de íon cloreto por técnica potenciométrica \\
\hline $\begin{array}{l}\text { NBR } \\
11331\end{array}$ & $\begin{array}{l}\text { Álcool Etílico - Determinação do teor de ferro por espectrofotometria de } \\
\text { absorcano atomica }\end{array}$ \\
\hline $\begin{array}{l}\text { NBR } \\
12120\end{array}$ & Álcool Etílico - Determinação do teor de sulfato por volumetria \\
\hline $\begin{array}{l}\text { NBR } \\
13993\end{array}$ & Álcool Etílico - Determinação do teor de hidrocarbonetos \\
\hline $\begin{array}{l}\text { ASTM } \\
\text { D512 }\end{array}$ & Chloride lon in Water \\
\hline $\begin{array}{l}\text { ASTM } \\
\text { D1125 }\end{array}$ & Electrical Conductivity and Resistivity of Water \\
\hline $\begin{array}{l}\text { ASTM } \\
\text { D1613 }\end{array}$ & $\begin{array}{l}\text { Acidity in Volatile Solvents and Chemical Intermediates Used in Paint, Varnish, } \\
\text { Lacquer and Related Products }\end{array}$ \\
\hline $\begin{array}{l}\text { ASTM } \\
\text { D4052 }\end{array}$ & Density and Relative Density of Liquids by Digital Density Meter \\
\hline $\begin{array}{l}\text { ASTM } \\
\text { D5501 }\end{array}$ & $\begin{array}{l}\text { Determination of Ethanol Content of Denatured Fuel Ethanol by Gas } \\
\text { Chromatography }\end{array}$ \\
\hline
\end{tabular}

Tabela I - Especificações do AEAC e do AEHC

\begin{tabular}{|l|l|l|l|l|c|}
\hline \multirow{2}{*}{ CARACTERÍSTICA } & UNIDADE & \multicolumn{2}{|c|}{ ESPECIFICAÇÕES } & \multicolumn{2}{c|}{ MÉTODO } \\
\cline { 2 - 7 } & & AEAC & AEHC & ABNT/NBR & $\begin{array}{c}\text { ASTM } \\
\text { (1) }\end{array}$ \\
\hline Aspecto & - & $(2)$ & $(2)$ & \multicolumn{2}{|c|}{ Visual } \\
\hline Cor & - & $(3)$ & $(4)$ & \multicolumn{2}{|c|}{ Visual } \\
\hline $\begin{array}{l}\text { Acidez total (como } \\
\text { ácido acético), máx. }\end{array}$ & $\mathrm{mg} / \mathrm{L}$ & 30 & 30 & 9866 & D 1613 \\
\hline $\begin{array}{l}\text { Condutividade elétrica, } \\
\text { máx }\end{array}$ & $\mu \mathrm{S} / \mathrm{m}$ & 500 & 500 & 10547 & D 1125 \\
\hline
\end{tabular}




\begin{tabular}{|l|l|l|l|l|l|} 
Massa específica a & $\mathrm{kg} / \mathrm{m} 3$ & $\begin{array}{l}791,5 \\
\text { máx. }\end{array}$ & $\begin{array}{l}807,6 \mathrm{a} \\
811,0(5)\end{array}$ & 5992 & $\mathrm{D} 4052$ \\
\hline Teor alcoólico & 9INPM & $\begin{array}{l}99,3 \\
\text { mín. }\end{array}$ & $\begin{array}{l}92,6 \mathrm{a} \\
93,8(5)\end{array}$ & 5992 & - \\
\hline $\begin{array}{l}\text { Potencial } \\
\text { hidrogeniônico (pH) }\end{array}$ & - & - & 6,0 a 8,0 & 10891 & - \\
\hline $\begin{array}{l}\text { Resíduo por } \\
\text { evaporação, máx. (6) }\end{array}$ & $\mathrm{mg} / 100 \mathrm{Ml}$ & - & 5 & 8644 & - \\
\hline $\begin{array}{l}\text { Teor de } \\
\text { hidrocarbonetos, } \\
\text { máx.(6) }\end{array}$ & $\% \mathrm{vol}$. & 3,0 & 3,0 & 13993 & - \\
\hline Íon Cloreto, máx. (6) & $\mathrm{mg} / \mathrm{kg}$ & - & 1 & $\begin{array}{l}10894 / \\
10895\end{array}$ & D 512(7) \\
\hline Teor de etanol, mín. (8) & $\% \mathrm{vol}$. & 99,6 & 95,1 & - & D 5501 \\
\hline Íon Sulfato, máx.(9) & $\mathrm{mg} / \mathrm{kg}$ & - & 4 & $10894 / 12120$ & - \\
\hline Ferro, máx. (9) & $\mathrm{mg} / \mathrm{kg}$ & - & 5 & 11331 & - \\
\hline Sódio, máx. (9) & $\mathrm{mg} / \mathrm{kg}$ & - & 2 & 10422 & - \\
\hline Cobre, máx. (9) (10) & $\mathrm{mg} / \mathrm{kg}$ & 0,07 & - & 10893 & - \\
\hline
\end{tabular}

(1) Poderão ser utilizados como métodos alternativos para avaliação das características nos casos de importação do álcool, com exceção do método ASTM D4052, que poderá ser sempre utilizado como método alternativo para a determinação da massa específica.

(2) Límpido e isento de impurezas.

(3) Incolor antes da adição de corante, segundo especificação constante da Tabela II deste Regulamento Técnico, que deverá ser adicionado no teor de $15 \mathrm{mg} / \mathrm{L}$ proporcionando ao produto a cor laranja.

(4) Incolor.

(5) Aplicam-se na Importação, Distribuição e Revenda os seguintes limites para massa específica e teor alcoólico do AEHC: 805,0 a 811,0 e 92,6 a 94,7 respectivamente.

(6) Limite requerido na Importação, Distribuição e Revenda, não sendo exigida esta análise para emissão do Certificado da Qualidade pelos Produtores.

(7) Procedimento C e modificação constante na ASTM D4806.

(8) Requerido quando o álcool não for produzido por via fermentativa a partir da cana-deaçúcar ou em caso de dúvida quando da possibilidade de contaminação por outros tipos de álcool.

(9) O produtor deverá transcrever no Certificado da Qualidade o resultado obtido na última determinação quinzenal, conforme previsto no $\S 1^{\circ}$ do $A r t .5^{\circ}$ da presente Resolução. 
(10) Deverá ser determinado no AEAC que tiver sido transportado ou produzido em local que possua equipamentos ou linhas de cobre, ou ligas que contenham este metal. (AEAC)

Tabela II - Especificação do corante a ser adicionado ao álcool etílico anidro combustível

\begin{tabular}{|c|c|c|}
\hline Característica & Especificação & Método \\
\hline \multirow{2}{*}{$\begin{array}{l}\text { Aspecto líquido visual } \\
\text { Família química } \\
\text { (\&quot;Color index\&quot;) }\end{array}$} & Solvent Red 19 ou Solvent Red 164 & - \\
\hline & Solvent Yellow 174 & - \\
\hline Cor & laranja & visual \\
\hline Absorvância a 420 nm & 0,150 a 0,190 & \multirow[t]{2}{*}{$\left({ }^{*}\right)$} \\
\hline Absorvância a 530 nm & 0,100 a 0,135 & \\
\hline Solubilidade & solúvel em $\mathrm{AEAC}$ e insolúvel em água & visual $\left({ }^{* *}\right)$ \\
\hline
\end{tabular}

$\left({ }^{*}\right)$ A absorbância deve ser determinada em amostra contendo $15 \mathrm{mg} / \mathrm{L}$ do corante em AEAC, medida em célula de caminho ótico de $1 \mathrm{~cm}$, no valor especificado para o comprimento de onda. AEAC.

$\left.{ }^{* *}\right)$ A solubilidade deve ser avaliada em amostra contendo $15 \mathrm{mg} / \mathrm{L}$ do corante em 